UNIVERSIDADE DE SÃO PAULO

FACULDADE DE FILOSOFIA LETRAS E CIÊNCIAS HUMANAS

DEPARTAMENTO DE TEORIA LITERÁRIA E LITERATURA COMPARADA

PROGRAMA DE PÓS-GRADUAÇÃO EM TEORIA LITERÁRIA

\title{
À SOMBRA DE MARTÍN FIERRO: SERGIO FARACO E MARIO ARREGUI
}

Eoná Moro Ribeiro

Tese apresentada ao programa de Pós-graduação em Teoria Literária, do Departamento de Teoria Literária e Literatura Comparada da Faculdade de Filosofia, Letras e Ciência Humanas da Universidade de São Paulo, para obtenção do título de Doutor em Letras

Orientadora: Profa ${ }^{\mathrm{D}}{ }^{\mathrm{a}}$ Ligia Chiappini Moraes Leite 
São Paulo

2007 
Dedicatórias

ao Caio Augusto, pela cumplicidade no decorrer desta pesquisa 


\section{AGRADECIMENTOS}

A realização deste trabalho só foi possível graças à colaboração direta e indireta de muitas pessoas. Manifesto minha gratidão a todas elas e de forma particular:

à minha orientadora, Profa ${ }^{\mathrm{Dr}}{ }^{\mathrm{a}}$ Ligia Chiappini Moraes Leite, por me ensinar, de maneira intensa, a cultivar a paciência e a persistência; pela transmissão de sabedoria;

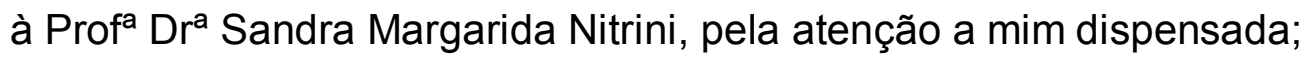

aos professores doutores, Sandra Margarida Nitrini e Flávio Wolf Aguiar, pelas sugestões e ensinamentos transmitidos na ocasião do meu exame de qualificação;

ao Luís, secretário da pós-graduação do Departamento de Teoria Literária, pelas informações;

ao escritor Sergio Faraco, por responder prontamente os meus e-mails e por me enviar alguns de seus livros e de Arregui. Agradeço também por me permitir a entrada em seu universo literário.

aos queridos amigos de Berlim, em especial Mauro e Érika, pela amizade e por me guiarem por essa cidade na ocasião de minha estadia na Alemanha;

aos funcionários da biblioteca do Instituto Ibero-Americano de Berlim, pelas infindáveis informações;

aos estudantes e funcionários do Instituto Latino-Americano da "Freie Universität", especialmente a Ana Maria Normann, pelo acolhimento;

à Ruth, por cuidar de certos e muitos afazeres;

à Capes, DAAD, Probral , por financiar minha viagem à Alemanha; 
ao CNPQ, pelo apoio financeiro no decorrer de todo essa pesquisa.

"Na medida em que soubermos administrar a unidade na diversidade, na medida em que entendamos o passado não como um paralisador paraíso perdido, mas como um elemento de explicação de nosso modo de ser, quando reconhecermos que a dimensão poliédrica da cultura gaúcha, antes de ser causa de dissensões, pode originar uma universalidade que nos dará espaço no novo milênio, estaremos a salvo."

Luiz Antonio Assis Brasil 
RIBEIRO, Eoná Moro. À sombra de Martín Fierro: Sergio Faraco e Mario Arregui. São Paulo, 2007. Tese (Doutorado em Teoria Literária) - Faculdade de Filosofia, Letras e Ciências Humanas, Universidade de São Paulo.

\section{RESUMO}

Esse estudo visou demonstrar a existência de uma literatura da atualidade que trata do gaúcho e do "gaucho" e do universo que o cerca por meio de formas e conteúdos específicos. Assim, são nossos objetivos evidenciar em que medida os contos de Sergio Faraco e Mario Arregui podem ser considerados gauchescos e apontar as semelhanças e as diferenças da literatura, tanto do escritor brasileiro como do uruguaio, no processo de criação de uma identidade regional fronteiriça, o que os classificaria como regionalistas num sentido amplo.

Palavras-chave: gaúcho, "gaucho", gauchesca, regionalismo, fronteiras.

\section{ABSTRACT}

This study sought to demonstrate the existence of a literature in the present time that shows the "gaúcho" and "gaucho" and their universe through specific forms and contents. This analysis tried to evidence the reason of Faraco's short stories and Arregui's short stories can be considered "gauchescos". This study also tried to show the similarities and the differences of literature, as much of the Brazilian writer as of the Uruguayan, in the process of creation of a bordering regional identity. 
Key words: "gaúcho”, "gaucho”, "gauchesca”, regionalism, borders.

\section{SUMÁRIO}

RESUMO

ABSTRACT

.5

INTRODUÇÃO

8

1.1- Sergio Faraco e Mario Arregui:vida e obra

8

1.2- O perfil do gaúcho e do "gaucho"

1.3- Ecos do Martín Fierro e a literatura gauchesca .13

1.4- O percurso literário

II. MARIO ARREGUI

1- A geração crítica do Uruguai

2- O "criollismo" e Mario Arregui

3- O "cuento de

fogón". .34

3.1- "Un cuento de fogón"

.36

3.2- "Contaba Don Claudio"

3.3- "El caballo piadoso"

4- Os contos de Arregui e a tradução de Sergio Faraco

5- Os contos de Arregui e o "gaucho"

5.1- "Noche de San Juan"

5.2- " El regresso de Odiseo González"

5.3- "Los contrabandistas"

68

5.4- "Tres hombres" 
5.6- "Diego Alonso" e "Un cuento con insectos"

.82

5.7- "La escoba de la bruja"

5.8- "Los ladrones"

III. SERGIO FARACO

.95

1- Sergio Faraco e sua obra

2- A literatura gauchesca no Rio Grande do Sul nos anos 1920 .98

3- O "projeto literário" do "mito do gaúcho-herói” e Simões Lopes Netto 100

4- De João Simões Lopes Netto a Cyro Martins

...........................................................104

5- Erico Verissimo

.107

6- O contexto das obras de Faraco

7- Os contos fronteiriços

7.1- "Lá no Campo" e "Aventura na sombra"

.115

7.2- "Dois Guaxos"

7.3- "Manilha de espadas"

7.4- "Travessia"

7.5- "Noite de matar um homem"

7.6- "Guapear com frangos"

...............................................................................130

7.7- "A voz do coração"

7.8- "O vôo da garça-pequena"

136

7.9- "Bugio amarelo" e "Adeus aos passarinhos"

7.9.1 - "Sesmarias do Urutau mugidor"

7.9.2- "Hombre"

7.9.3- "Velhos" 
V. APÊNDICE I - Resumo dos contos

"Un cuento de fogón"

"Contaba Don Claudio"

"El caballo piadoso"

"Noche de San Juan"

"El regresso de Odiseo González"

"Los contrabandistas"

164

"Tres hombres"

“ Un cuento con un pozo"

"Diego Alonso"

166

"Un cuento con insectos"

"La escoba de la bruja"

"La escoba de la bruja"

"Los ladrones"

2- Contos de Faraco

"Lá no Campo"

"Aventura na sombra"

"Dois Guaxos"

"Manilha de espadas"

"Travessia"

"Noite de matar um homem"

"Guapear com frangos"

"A voz do coração"

"A...................................

"O vôo da garça-pequena" 
"Bugio amarelo"

"Adeus aos passarinhos"

"Sesmarias do Urutau mugidor"

"Hombre"

"Velhos"

VI. APÊNDICE II - Observações sobre Juan José Saer .............................................175

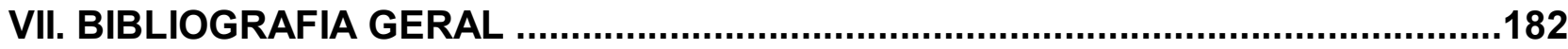

\section{INTRODUÇÃO}

1- Sergio Faraco e Mario Arregui: vida e obra

"Desde la primera lectura me gustaron mucho tus relatos, la mayoria relacionados al campo y, algunos de ellos, creando un cierto perfil del gaucho."

Esse comentário do escritor Sergio Faraco (nascido em Alegrete, Rio Grande do Sul, em 1940) chegou a Mario Arregui (nascido em Trindad, capital do departamento de Flores - Uruguai, em 1917) por meio de uma carta datada em 11 de julho de 1981, uma das primeiras trocadas entre os escritores. A correspondência entre eles vai durar quase quatro anos e será interrompida pela morte de Arregui em fevereiro de 1985. Todas essas cartas reunidas deram origem ao livro de Corrrespondência, publicado em Montevideo em 1990.

Tal intercâmbio inicia-se quando Faraco, em meados dos anos 1981, escreve uma carta dirigida à Editora Arca do Uruguai, pedindo a autorização para traduzir os contos de 
Mario Arregui no Brasil. A Editora comunica-se com Arregui, que logo (3 de julho de 1981 ) entra em contato com Faraco. Como todo escritor, tinha interesse na tradução dos seus livros.

A partir daí, vai surgir uma intensa "troca" de experiências, que vislumbra tanto o cotidiano quanto à criação literária desses dois escritores latino-americanos, fronteiriços. Podem ser considerados fronteiriços não só no sentido da territorialidade, já que pertencem a países vizinhos, mas também, e especialmente, no sentido cultural. Ou seja, as fronteiras, cuja concepção é inicialmente ancorada na territorialidade e no político, induzem "a pensar na passagem, na comunicação, no diálogo e no intercâmbio" cultural, o que implica uma transcendência, acima e antes da geopolítica. "Fronteiras culturais remetem à vivência, às sociabilidades, às formas de pensar intercambiáveis, aos ethos, valores, significados contidos nas coisas, palavras, gestos, ritos, comportamentos e idéias." E "a fronteira cultural é trânsito e passagem, que ultrapassa os próprios limites que fixa". Assim, Sergio Faraco busca o diálogo com Arregui porque reconhece que a literatura do escritor uruguaio, assim como a sua, cria "un cierto perfil do gaucho" "algo novo e diferente, pela situação do contato, da mistura, da troca."

Mas, antes de nos remeter à literatura desses dois escritores, constatamos que a primeira possibilidade de estabelecer o diálogo entre eles é através de suas vidas. Arregui era dono de terras, assim como Faraco é, o que nunca impediu ambos de militarem sempre na esquerda. Faraco é advogado. Mario Arregui foi estudante de advocacia, mas não se formou. É o próprio Arregui que, em uma de suas cartas a Faraco, em 18 de julho de 1981, faz uma descrição breve de si mesmo e uma comparação entre ele e o brasileiro:

"Tengo 23 años más que vos. No creo ser muy simpático, salvo para mis amigos (tengo muchos; algunos, ay, ya están muertos). Creo que mi mujer, como la tuya, opina bien de mi. Llevo dos matrimonios; creo que la bigamia, y aún la trigamia, es el estado ideal; razones de edad me constriñen ahora la monogamia. Tengo 3 hijos, 7 nietos, una hijastra. Arrastro la gran pena de un hijo muerto en un accidente. Como vos, poseo tierras, lo que no me ha impedido militar siempre en la izquierda. Esa militancia me costó en 1977 casi 8 meses de cárcel. Vos sos abogado; yo fui estudiante de abogacía, pero, con más suerte que vos, largué a tiempo esas porquerías codificadas. En mis tiempos fui muy buen jinete. Como jugador de fútebol siempre fui muy malo. A mi estancia y cabaña (de Holando) la atiende ahora uno de mis hijos - en medio de la gran crisis económica que asfixia a este país; se vaticina un 
derrumbe como el argentino para dentro de pocos meses. Mi otro hijo está en España - es pintor. El otro - que es la otra - , una mujer - vive en Montevideo. El último día de 1978 hice un infarto y estuve moribundo o casi muerto; con un marcapasos, ando ahora muy bien."

Primordialmente, é interessante constatar que Faraco é um contista por excelência. Seus livros de contos são Idolatria (1970), Depois da Primeira Morte (1974), Hombre (1978), Manilha de espadas (1984), Noite de Matar um homem (1986), Doce Paraíso (1987) e A dama do Bar Nevada (1987). Majestic Hotel (1991). É lançada, em 1995, a primeira edição dos Contos Completos. Depois de 1995, surgiram: Dançar tango em Porto alegre e outros contos escolhidos (1998) e Rondas de Escárnio e Loucura (2000). O primeiro faz parte da série "Pocket" da editora L\&PM e se configura como uma espécie de edição reduzida dos Contos Completos, dividido também em três partes, mas com um menor número de contos em cada uma delas. O segundo é composto por 11 contos também tomados dos Contos Completos. Em 2004, surge a segunda edição dos Contos Completos. -

Apesar do destaque no panorama da literatura brasileira como contista, Sergio Faraco escreveu crônicas reunidas nos livros $\underline{O}$ chafariz dos turcos (1990), A lua com sede (1993), Gregos e gringos (1998), Viva o Alegrete (2001) e traduziu inúmeros livros de escritores uruguaios (Mario Arregui, Mempo Giardinelli, Juan José Morosoli, Carlos Maggi, Júlio Muguia, Jesús Moraes,Tomás de Mattos, Horacio Quiroga, Idea Vilariño), argentinos (José Gabriel Ceballos, Roberto Arlt), paraguaios (Raquel Saquier, Guido Rodríguez Alcalá), italianos (Máximo Gorki). Além disso, organizou inúmeras edições, participou de muitas antologias, publicou Noche de matar um hombre (1988), no Uruguai e ainda escreveu outros livros: Urutau (1978), Tiradentes: alguma verdade (ainda que tardia) (1980); Dicionário de autores contemporâneos (1983), 0 processo dos inconfidentes (1990), O automóvel: prazer em conhecê-lo (com Hugo Almeida em 2001). Em 2002, publicou um livro de memórias baseado em sua estadia na antiga URSS de 1963 a 1965, intitulado Lágrimas na chuva: uma aventura na URSS.

A obra de Arregui também é constituída, em sua maioria, por livros de contos: Noche de San Juan (1956); Hombre y caballos (1960); La sed y el agua (1964); Tres libros de cuentos (reúne a mayor parte dos contos anteriores e agrega "Un cuento con un 
pozo" (1969)); El narrador (1972); La escoba de la bruja (1979). Em 1964, escreveu Líber Falco, livro de testemunho sobre esse poeta uruguaio, amigo de Arregui.

Em 1985, foi publicado o livro póstumo Ramos Generales, gestado nos anos de correspondência com Faraco. Arregui afirmou que essa obra recebeu esse título porque, como algumas casas, que vendiam um pouco de tudo ("desde rejas de arado a naipes y ventosas, desde brazaletes para lutos a lazos de catorce brazadas, desde recados a peines saca-piojos y chupetas, desde alambre de puas a agua florida, desde mata-bicheras a mortadela...) não difíceis de encontrar na campanha uruguaia, apresenta "um lote de cosas muy diferentes", como contos, ensaios e um testemunho de sua viagem à Europa em 1971.

Em 1992, foram publicados pela Arca os Cuentos Completos (tomo I e II) que reúnem Noche de San Juan, Hombres y caballos (tomo I) e La sed y el agua, La escoba de la bruja (tomo II).

Faraco, na carta de 11 de julho de 1981, afirma que possui El narrador e $\underline{\text { Tres }}$ libros de cuentos. Ao saber disso, Arregui the envia La escoba de la bruja, livro no qual repete 5 contos que já estavam no El narrador e acopla 5 contos inéditos. Como Faraco, Arregui republicava seus contos, porque via a necessidade de ajustar palavras, pontuação, modificações, muitas vezes, imperceptíveis. Sergio Faraco constata:

\begin{abstract}
"Por tu carta - y también por lo que ya observara a través de la lectura veo que tienes la "mala costumbre" de rehacer textos antiguos, buscando la mejor forma de decir. Ese hábito es otro elemento que me identifica con tu trabajo: lo conozco (y me recrimino por eso). Para publicar Hombre rehice algunos relatos publicados anteriormente en otros libros. Soy un eterno insatisfecho y siempre me parece que un día más de vida me da elementos para pensar mejor un texto."
\end{abstract}

\title{
2- O perfil do gaúcho e do "gaucho"
}

Existem, indubitavelmente, semelhanças tanto na vida quanto na obra desses dois escritores. Mas, como observado anteriormente, o interesse de Faraco em traduzir os contos de Arregui surge porque o escritor brasileiro reconhece que a literatura do uruguaio está vinculada ao campo e à criação de um "certo" perfil do gaúcho: 
"Desde la primera lectura de tus cuentos, una noche en Bella Unión, pensé en traducirte, encantado con la fuerza de tu literatura, en buena parte ligada a nuestra tierra y nuestra gente. Uruguay y Rio Grande se parecen. Pero Rio Grande es brasileño y sufre todas las influencias del imperialismo cultural del centro del país. En ese contexto, tus relatos recuperan al gaucho como tipo humano, con sus peculiaridades $y$, exagerando, con su "nacionalidad".

Mas que "tipo" de "gaucho" é esse que povoa os contos de Arregui? Em que ele se parece ou se diferencia do gaúcho dos contos fronteiriços de Faraco?

Sabemos que essa figura habita ou habitou a comarca pampeana "área que engloba trechos da Argentina, do Uruguai e do Brasil, onde há a homogeneidade de elementos naturais, étnicos, culturais que convergem em formas similares de criação artística."

O uso do verbo "habitar" no pretérito perfeito sugere que esse homem já não existe mais, questão já retomada por Alejandro Losada que fala de sua morte e encara o Martín Fierro, escrito em 1872 pelo argentino José Hernandez, como a obra que demonstra o fim desse tipo socialmente localizável.

$\mathrm{Na}$ verdade, muitos estudiosos têm se debruçado sobre a origem da palavra "gaucho"-gaúcho para demonstrar que nem sempre esse significante ficou restrito ao signifcado do homem corajoso, viril dos Pampas.

Do lado brasileiro, Augusto Meyer no excelente estudo "Gaúcho, história de uma palavra", afirma que essa figura, no princípio, foi ladrão e vagabundo. Mas, os capitães de milícias e comandantes de tropas em guerras de fronteira o consideravam um bom auxiliar. Durante as campanhas do sul, ele desempenhou a tarefa de militar. Mais tarde, para o homem da cidade seria - de forma simultânea ou alternativa - um trabalhador rural, peão de estância, agregado e habitante da campanha. No decênio da Guerra dos Farrapos (1835-1845), adquiriu um sentido encomiástico e, em 1893, adquiriu um sentido cívico referindo-se aos que lutavam pela causa federal. Por último, na atualidade, refere-se aos habitantes do Rio Grande do Sul.

Os historiadores uruguaios Washington Reyes Abadie e Andrés Vázquez Romero, em Crónica General del Uruguay, citam um documento datado de 8 de agosto de 1780, que diz : “... que el expresado Díaz no consentirá em dicha estancia que se abriguen ningunos contrabandistas, vagamundos y ociosos que aqui se conocen por gauchos...”. 
Depois de citarem esse documento, os historiadores comentam que a sinonímia entre "contrabandistas, vagabundo y ocioso" com o vocabulário "gaucho" não deve, entretanto, estender-se à condição deste protótipo da "edad del cuero". Na verdade, há outro documento de importância reveladora. "Noticia sobre los campos de la Banda Oriental" de autor anônimo, de 1794, diz: "Los gauchos son también de dos clases: o meros jornaleros que sirven al que los alquila o changadores, que viven del contrabando y de robar ganado y hacer faenas por un precio que conciertan con el hacendado que los solicita. $Y$ ambos viven sin domicilio, agregados a las estancias o en el centro de la tierra persiguiendo ganado." Por meio desse documento, Abadie e Romero concluem que aparecem, a partir desse documento, as duas condições do "gaucho" que caracterizam sua vida histórica até que se extingue no último quarto do século XIX: "peón o vagabundo". Mas acrescentam que na "hora revolucionaria de la "regeneración" de las patrias americanas del Plata," seria também "heróico miliciano de la libertad". Depois há o surgimento de toda uma literatura que habría de glorificar o "gaucho", "exaltándolo a la categoria de paradigma y símbolo de la estirpe americana de nuestros povos."

"Matrero, guerreiro e peão campeiro", essas são as características que descrevem o gaúcho e o "gaucho". Porém não cabe aqui, indagar a existência do gaúcho real, o que só um estudo sociológico, demográfico e econômico poderia fazer. O que interessa é rever os contos de Faraco e Arregui para evidenciar que existe uma literatura da atualidade que continua a tratar desse homem dos Pampas e do universo que o cerca, por meio de formas e conteúdos específicos a serem retratados no decorrer do trabalho.

\section{3- Ecos do Martín Fierro e a literatura gauchesca}

O gaúcho de Faraco e o "gaucho" de Arregui em pouco se parecem com a sua construção ideologizada que vigorou, como veremos adiante, tanto no Brasil, como no Uruguai por volta dos anos 1920.

Podemos dizer que a obra desses dois escritores tem muito mais a ver com o Martín Fierro, ou seja, com a literatura gauchesca do argentino José Hernández, escrita num período em que a modernização na "comarca pampeana" cortou, por meio das cercas, dos alambrados, a vida do gaúcho e do "gaucho" . Já na $1^{a}$ estrofe do $3^{\circ}$ canto, Martín Fierro, em $1^{\mathrm{a}}$ pessoa, narra a síntese de toda a sua trágica biografia:

\footnotetext{
"Tuve en mi pago em um tiempo
} 
hijos, hacienda y mujer;

pero empecé a padecer,

me echaron a la frontera,

y qué iba a hallar al volver!

Tan sólo hallé la tapera."

A transformação da vida do "gaucho", jogado nas guerras de fronteiras, perseguido pelas autoridades, "a pie y mostrando el umbligo,/ estropiao, pobre y desnudo" é mostrada com maestria na obra de Hernández.

Essa obra fala a brasileiros, a uruguaios, a argentinos, porque elegeu um tipo fronteiriço representante das mazelas sofridas pelos homens pobres do campo de um e de outro lado, que compartilham da cultura gaúcha na região de fronteira.

Além de ficar evidente que há a existência da intertextualidade explícita, entre o texto de Hernández e de Arregui, como é adensado pela análise, esse trabalho não visa a mostrar com exaustão quais fatos, processos e mitos nos contos, tanto de Arregui como de Faraco, tem a ver com Martín Fierro; ou seja não faremos um estudo da recepção dessa obra na literatura dos dois escritores. Retomaremos a obra de Hernández, de maneira indireta, para evidenciar que o gaúcho e o "gaucho" pobre de Faraco e Arregui tem muito do Martín Fierro, personagem, no início, rebelde, mas depois, integrado e de ira aplacada, sempre excluído, sem terra, sem chão, sem rumo.

O foco principal é, atentando ao texto e contexto em que a obra foi escrita, evidenciar como o gaúcho pobre, desamparado, "a pé" continua a contagiar a literatura desses dois escritores contemporâneos.

Impossível expor sobre "gauchos" e gaúchos sem remeter à gauchesca. Nesse sentido, cabe perguntar: os contos de Faraco e Arregui fazem parte da literatura gauchesca? Questão que se não amplamente respondida, terá o mérito de plantar a dúvida para novos trabalhos. Entretanto o que seria a denominada literatura gauchesca?

Ángel Rama, quando começa a discorrer sobre o assunto faz uma observação chave: "una cosa es el gaúcho y outra la llamada literatura gauchesca"

É óbvio que a literatura gauchesca aborda temas relacionados ao universo do gaúcho, mas, como o próprio Rama afirma, é preciso reconhecer que essa poesia, em muitos momentos, (que teve como iniciador o uruguaio Bartolomé Hidalgo (1788-1822)) esteve envolvida por uma ideologia. Assim, é necessário questionar quem escreveu esses poemas, por que e para quem fizeram e que princípios animavam os escritores. 
Em primeiro lugar, Rama esclarece que esses autores da literatura gauchesca não foram, na maioria das vezes, "gauchos", mas sim homens da cidade com níveis educacionais muito variados, nunca confundíveis com os "gauchos" dos pampas. Viveram em cidades do Rio da Prata desde a Revolução da Independência (1810) até o início do século $X X$ e escreveram suas obras poéticas em íntimo consórcio com os sucessos históricos do seu tempo. Exercitaram a gauchesca dentro das diversas tendências de cada período: Hidalgo, no neoclássico; Ascasubi, no primeiro período romântico e Hernández na maturidade do realismo. No momento da produção da gauchesca, os poetas ocupavam o estrato mais baixo da produção literária pelo motivo de se comunicarem com um público praticamente analfabeto, alheio aos circuitos das artes e das letras, utilizando suas formas expressivas e tratando de seus problemas.

Para Rama, a fundamental e básica opção que fizeram os gauchescos, o que iria reger sua estética e sua poética (mas nem sempre sua ideologia) e o que permite que os agrupemos em um movimento foi o público. Na obra de Hidalgo, por exemplo, o aparente emissor da mensagem, o contexto ou o referente sobre o que se conta e canta e o destinatário do produto são visivelmente o "gaucho". A opção de um público era condição para se articular os demais elementos que compunham a mensagem poética (personagens, situações, língua, formas literárias, emissor aparente), questão já percebida por José Hernández em 1879. Assim é uma literatura quase sempre que provém de um gaúcho, emissor que fala a outros gaúchos. Esse público compunha-se de uma maioria da população rio-pratense, de procedência rural, formada nas entranhas analfabetas de uma cultura tradicional, distribuída por campos e cidades, e que foi submetida por mais de um século a uma série de violências freqüentemente inexplicáveis para ela; inexplicáveis agitações; população que foi arrancada de suas antigas rotinas para ser incorporada a uma história dinâmica, presente e urgente.

Mas, já que a literatura gauchesca desenrola-se num espaço de tempo de mais de um centenário, não se pode falar de um único e homogêneo público. A distância entre a "gauchada" em combate a que trata de alcançar Hidalgo com seus "cielitos" e o público suburbano ao qual se dirige Alonso y Trelles com Paja brava (1915) é enorme.

O primeiro escritor a atrair a atenção de um público culto para a literatura gauchesca é Estanislao del Campo. No final do século XIX, haverá um público nacional que se interessará pela gauchesca, mas essa literatura nunca deixará o caráter popular. 
Isso explica seu manejo pelos intelectuais do peronismo nas décadas de quarenta e cinqüenta do século $X X$.

Apesar de essa literatura ser direcionada a um público específico, nem sempre ela estará a serviço dele, interpretando e favorecendo seu desenvolvimento histórico. Pelo contrário, com freqüência responderá aos grupos hegemônicos, detentores do poder oficial de uma época, que instrumentalizavam a arte e as letras que se destinavam aos estratos submetidos. A produção gauchesca do período rosista é uma boa demonstração da discordância que pode manifestar entre a opção de um público popular e a ideologia. Serve para afirmar a posição dual que pode assumir o escritor: poderia tanto responder às demandas reais e urgentes do público ao qual se dirigia (como exemplo temos Hidalgo), ou poderia atuar a serviço de um grupo social distinto, mediante formas persuasivas de literatura que escamoteiam a realidade. Hilário Ascasubi (1807-1873), poeta argentino, muito mais que Estanislao Del Campo (1834-1880), também argentino, foi o protótipo do poeta gauchesco a serviço de um setor ilustrado superior.

A motivação ideológica surge no período da Independência , quando o grupo que orienta a batalha necessita do apoio do estrato "gaucho" inferior e, através da literatura de Hidalgo, integra-o ideologicamente ao processo revolucionário.

O manejo ideológico que o escritor procura transmitir pertence ao presente histórico e a suas mais visíveis e urgentes demandas, pois explica a luta armada contra espanhóis e portugueses e justifica a insurreição contra os poderes instituídos. Mas ao público "gaucho", será transmitido com uma estrutura artística do tempo passado, criando assim a base desse híbrido produto - a poesia gauchesca - que maneja o pensamento revolucionário da época mediante as décimas e redondilhas octossílabas.

A conquista posterior do pampa, o alambramento dos campos, a implantação dos severos códigos rurais, o impulso de uma economia de exportação requisitada nos mercados europeus são sucessos contemporâneos do $3^{\circ}$ período da gauchesca. Nele, encontramos o poeta uruguaio Lussich (1848-1928) e o argentino José Hernández (1834-1886) com quem a poesia gauchesca deixa de ser política para ser social, manipulando uma ideologia reivindicativa primeiro, no seu viril momento realista, e logo nostálgica quando a derrota dos vencidos impõe-se e se elevam seus lamentos.

E os contos de Arregui podem ser denominados gauchescos? No Brasil, existe ou existiu literatura gauchesca? Carlos Leumann afirmou que "fuera de la Argentina y del Uruguay nunca hubo nada equivalente a la literatura gauchesca". Em que sentido 
podemos considerar os contos de Faraco como parte de uma literatura gauchesca? Questões a serem debatidas no decorrer do trabalho.

\section{4- O percurso literário}

Para entender esse "homem fronteiriço", tanto na obra do escritor brasileiro, como do uruguaio, é preciso revisitar certas obras e autores, tanto de um lado como de outro, já que trazem reminiscências, por meio de forma e conteúdo específicos a sua literatura, do gaúcho e "gaucho" do passado. Dessa forma, para refletir sobre a criação literária atual de Faraco e Arregui, que possui como protagonista esse homem, é necessário rever como ele habitou a ficção do passado.

Além disso, as semelhanças e as diferenças da literatura desses dois escritores no processo de criação de uma identidade gaúcha regional fronteiriça serão objeto do nosso estudo. Nesse sentido, por muitos de seus contos elegerem como espaço uma região específica, a "comarca pampeana", poderíamos considerá-los escritores regionalistas? Mario Arregui é "criollista"? Todas essas questões exigem fôlego para serem respondidas.

Verificaremos ainda como o social e o estético se conjugam em seus contos. Isso significa que daremos atenção também ao contexto em que essas narrativas foram escritas, para evidenciar que, embora muitas delas resgastem o gaúcho e o "gaucho" do passado, elas estão presas ao processo histórico, político e social do momento da escrita e não pretendem evidenciar o lado heróico desse homem, mas sim um passado que precisa ser revisto para explicar o presente.

Interessante também será constatar, em alguns momentos, a visão dos fatos históricos abordados no enredo dos contos para discutir a identificação ou não desses dois escritores com a historiografia que circulava respectivamente em seus países no momento da escrita. Essa análise confirmará a busca desses dois escritores por uma visão da História que problematiza a ideologia dominante.

Começaremos a análise por Mario Arregui , evidenciando em que contexto do Uruguai e da literatura uruguaia aparecem suas obras, o que vai determinar a maneira de ele encarar o "gaucho". A seguir, passaremos a analisar os contos de Faraco, e já nos preocuparemos em fazer as pontes entre esses dois escritores. $\mathrm{Na}$ conclusão, confrontaremos todo o analisado para responder as perguntas esboçadas. 
Dispomos um apêndice no final do trabalho com o resumo de cada um dos contos analisados, para melhor orientar o leitor.

Ademais, como abordado, Faraco traduziu contos de Arregui. Não cabe a esse trabalho fazer uma análise profunda dessa tradução. No entanto, em alguns momentos, retomaremos os contos traduzidos como auxiliares na interpretação dos textos de Arregui. 


\section{MARIO ARREGUI}

\section{1- A Geração Crítica de 45 do Uruguai}

Os contos escritos por Arregui demonstram sua eterna busca pela palavra precisa, por uma linguagem erudita, que herdou de Borges e Onetti, escritor uruguaio que "había planteado ya en los años trinta la necesidad de crear una narrativa ciudadana."

Na verdade, é difícil definir com exatidão a que geração pertence o uruguaio Mario Arregui. Ele escreveu seu primeiro conto em 1947, num momento em que jovens escritores, como Mario Benedetti (nascido em 1920), desejavam reatar os vínculos com a atividade cultural européia e ficar em dia com a cultura do pós-guerra. Benedetti, Emir Rodríguez Monegal, Carlos Martinez Moreno, leda Vilariño e tantos outros não desdenhavam a identidade lingüística e histórica da região, pautada sobretudo no campo, mas almejavam a uma comunicação cosmopolita. Foi uma geração que desejava "la recuperación para la literatura del âmbito lingüístico rio-platense y el rechazo de una retórica condicionada por el prestigio de la literatura española y por la tradición gauchesca."

O livro denominado "70/'90: Antología del cuento uruguayo" possui como prólogo um estudo interessante cujo título é "El cuento uruguayo actual, sus modelos culturales y la modernidad". Nele, o crítico literário uruguaio Rómulo Cosse afirma que a ficção uruguaia contemporânea desdobra-se em duas grande vias: por um lado, há "la prolongación del realismo europeo" e, por outro, "la línea de la ruptura, de la fisión o del estallido de esse modelo". Afirma que o "canon realista" conta com ilustres antecedentes como a escrita de Acevedo Díaz, Reyles, Viana, Morosoli, Espínola e pode descrever-se com as seguintes características: 1) um narrador exterior à história e não representado (sem nome, sem rosto, pura ficção narrativa) que comunica um conhecimento irrestrito formulado em terceira pessoa; 2) estabilidade na função do protagonista, chegando ao extremo de em algumas obras, de certo modo canônicas, o sujeito dar nome ao romance (Beba, Ismael, Gaúcha, etc...); 3) simetria entre a ordem causal dos fatos (trama) e a disposição que no relato assumem tais fatos (argumento); 4) a causalidade que rege e explica as transformações dessa história é do tipo natural, ao mesmo tempo que se deseja o nexo lógico entre a maioria dos episódios contados; 5) a descrição consiste principalmente em quadros ou unidades fechadas e completas (como retratos), de modo 
que é descrita uma série de predicados de estado de um dado sujeito, num mesmo segmento textual.

A partir do romance "El pozo" (1939) de Onetti, ocorre "la ruptura del canon realista". Algumas características dessa "inédita forma de modelar el mundo" são: 1) abandono do narrador estável e de saber irrestrito ou ao menos sua presença alternada com a de outros tipos de narradores; 2) desaparecimento dos quadros descritivos; 3) as relações trama-argumento invertem-se com mais freqüência; 4) a causalidade abandona a ordem natural de maneira mais reiterada; 5) a função do papel de protagonistas já não é estável como antes; 6) é introduzido um procedimento que se não é original em si inova o texto narrativo, ou seja, há trechos não ligados com os seguimentos precedentes da narração; 7) há o trabalho intertextual que consiste na integração de segmentos de discurso de outros textos na continuidade da narração sem nenhuma marca de citação.

Essas características podem apontar se uma obra pertence ao modelo tradicional ou apresenta elementos de ruptura; porém "como tantas veces ocurre en arte, podrán darse casos donde se combinem en relaciones variables, factores del orden realista y experimental"

O projeto cultural de 45 no Uruguai adota essa postura experimental, "neorrealista y uma nueva exigência de calidad, en contraste con el romanticismo epigonal y el estancamiento provinciano de nuestros literatos, quienes vivian apoltronados en la falsedad del elogio recíproco." Além disso, "el proyecto cultural del " 45 " reclamaba una elevación de nivel de exigencia intelectual y artística, y presuponía una formación cosmopolita que trascendiera las limitaciones pueblerinas. Se soslayaba o menospreciaba el arte popular."

Os contos de Arregui assimilam tanto os elementos tradicionais como a nova proposta da Geração Crítica, nome também dado aos escritores de "45". Porém o escritor, como faz questão de afirmar, não é um "criollista".

\section{2- O "criollismo" e Mario Arregui}

Num primeiro momento, é extremamente problemática a definição de literatura "criollista" que se confunde com "campera", "nativista".

Já no prólogo de La escoba de la bruja, Arregui diz que não quer ser um escritor de certo tipo de "criollismo". Em uma das cartas a Faraco, afirma: 
"(...) Pero repárese que digo "criollismo usual" o sea aquél que se limita a asediar lo típico o particular, que pretende explotar los pintoresquismos del color local, que al fin de cuentas es una forma del mal folclore..."

Essa explicação de Arregui poucas pistas oferecem do seu repúdio a esse tipo de literatura. Mas é o próprio Arregui que também no livro Correspondência possibilita o caminho para entender um pouco melhor essa produção literária. Ele diz que no seu próximo livro que se chamará Ramos Generales incluirá um pequeno ensaio intitulado "Literatura y bota de potro", onde joga pedras mal humoradas ao "criollismo literário usual."

Importante é a análise dos ensaios de um escritor, pois eles abordam seu mundo literário, seus juízos de valor, imprescendíveis para afinar a análise de sua obra. No ensaio acima citado, antes de definir o que foi o "criollismo", Arregui acerta contas com o "gaucho" e a literatura gauchesca.

Num tom um tanto quanto bem (ou mal?) humorado pincela objetivamente, "às secas", o que foi esse tipo humano:

\begin{abstract}
"El gaucho (suma e aleación de heterogéneos sumados: dos tres razas mescladas, campo sin alambrar, el cabalo que es pedestal y es distancia y proporciona un módico nomadismo, gotas de senequismo e goterones de buen orgullo también estoico, tiempo sin horas y aun sin días, relámpagos de barbarie más o menos inocente, el gran cuchillo que vierte sangres indiferenciables de hombres e bestias, el sustento en las reses de nadie al alcance del lazo, la mujer y lo femenino más bien faltando, Dios muy lejos o no siendo problema...) fue un singularíssimo ser humano en quien la utopía anarquista, quizá por única vez en la historia del mundo, anduvo pisando la tierra con pies de carne y hueso. Se trataría, pues de la materialización de un sueño: la encarnación de un viejo sueño en hombres que Sarmiento pudo ver más bien como la fauna de una pesadilla. (Conviene no olvidar que desde su nacimiento, allá por el último tercio del siglo XVII, hasta casi mitad del siglo pasado, la voz gaucho fue francamente peyorativa, incluso condenatoria)
\end{abstract}

Arregui, num tom de desmistificação e equilíbrio, faz um ajuste de contas com esse homem "de carne e osso" que habitou a comarca pampeana. Se ele é sinônimo de barbárie para Sarmiento, essa barbárie para Arregui é inquestionável ("el gran cuchillo que vierte sangres indiferenciables de hombres e bestias"), mas tem o porquê de ser, já que foi um homem forjado numa natureza rude, no nomadismo. Também é, 
indubitavelmente, um ser que pode inspirar "grandes sonhos" (não é à toa que tanto escritores do Brasil como do Uruguai e da Argentina utilizam essa figura, ungindo-a com os predicados de valentia e coragem), principalmente por ser errante e vagar "sin horas" y "sin dias".

Arregui vai procurar nos estudos de Feliz de Azara, Francisco Bauzá e Florencio Sánchez, intelectuais que vivem numa época em que existiam "gauchos" a descrição desses "semi-bárbaros":

"De esos hombres semi-bárbaros anotó don Félix de Azara: "Su desnudez, su larga barba, su cabello nunca peinado y la oscuridad y porquería de semblante, los hacen espantosos a la vista". De esos hombres estamparía después Francisco Bauzá “... los verdaderos gauchos, mezcla informe de grandes pasiones y de pensamientos mezquinos, arrojados e pueriles, trovadores melancólicos que al son de la guitarra cantaban endechas de amor, y en seguida reñían a cuchillazos por la menor palabra; valientes hasta la temeridad y supersticiosos hasta la ridiculez". Sobre un rasgos de esos hombres escribiría también Florencio Sánchez, en sus famosas Cartas de un flojo: “... esa suspicacia aviesa, chocarrera y guaranga que se cristaliza no gaucho aericano".

No ensaio de Arregui, todas essas observações são colocadas para chegar ao ponto central da discussão: o "gaucho" como representante do nacional no Uruguai. Arregui descreve uma estátua, na praça central de Montevidéu, que recorda o "gaucho" e o homenageia com os seguintes dizeres gravados no mármore ao seu pé: "AL GAUCHO/Primer elemento de emancipación nacional y de trabajo. La patria agradecida." Todavia, Mario Arregui constata que poucas vezes a pátria tem agradecido "con tan mala puntería".

Desmistificar essa figura é o objetivo o escritor uruguaio, pois aponta que o "gaucho" foi muitas coisas e outras "muchíssimas no fue". Entre as que não foi ressalta: a) um patriota; b) um trabalhador. Afirma que o "gaucho" não sentiu a pátria, "sólo sintió el pago, palpaple patria chica, y sobre todo la querência, calentita patria minúscula.":

“"El gaucho está, o estaba, totalmente desprovisto de sentimientos patrióticos", escribe nadie menos que G. E. Hudson en su cuento El Ombú, donde relata que los gauchos de Quilmas bromeaban muy amistosamente con los soldados ingleses que se encaminaban al asalto de Buenos Aires, y añade que en tan importante momento histórico los susodichos naturales se dedicaban a divertirse con el juego de El Pato y 
sólo se preocupaban de rebuscarse de las frazadas, que para aligerar la marcha, iban dejando caer las tropas invasoras.

(...)

En cuanto a elemento de trabajo, creo que a él más que al destinatario original, un compadrito orillero tal vez con un abuelo gaucho y muy probablemente veteado de italianismo, caen como anillo al dedo los versos de aquel tango que dice "la esquena se te frunce si tenés que laburarla" y "si encontrás al inventor del laburo lo fajás". Hablo del gaucho no del paisano-gaucho (la justa y necesaria diferenciación es de Lucio $\mathrm{V}$. Mansilla), ese espécimen que anda por ahí con una suerte de adhesión asustada al patrón, al caudillo, al comisario, al trabajo, a la decencia..."

Lucio V. Mansila , em 1870, faz a diferença entre "paisano-gaucho" e "gaucho":

"Son dos tipos diferentes. Paisano gaucho es el que tiene hogar, paradero fijo, hábitos de trabajo, respeto por la autoridad, de cuyo lado estará siempre, aun contra su sentir.

El gaucho neto, es el criollo errante, que hoy está aquí, mañana allá; jugador, pendenciero, enemigo de toda disciplina; que huye del servicio cuando le toca, que se refugia entre los indios si da una puñalada, o gana la montonera si ésta asoma.

El primero, tiene los instintos de la civilización; imita al hombre de las ciudades en su traje, en sus costumbres. El segundo, ama la tradición, detesta al gringo; su lujo son sus espuelas, su chapeado, su tirador, su facón. El primero se quita el poncho para entrar en la villa, el segundo entra en ella haciendo ostentación de todos sus arreos. El primero es labrador, picador de carretas, acarreador de ganado, tropero, peón de mano. El segundo se conchaba para las yerras. El primero ha sido soldado varias veces. El segundo formó alguna vez parte de un contingente y en cuanto vio la luz se alzó.

El primero es siempre federal, el segundo ya no es nada. El primero cree todavía en algo, el segundo en nada. Como ha sufrido más que la gente de frac, se ha desengañado antes que ella. Va a las elecciones, porque el Comandante o el Alcalde se lo ordena, y eso se hace sufragio universal. Si tiene una demanda la deja porque cree que es tiempo perdido, se ha dicho con verdad. En una palabra, el primero es un hombre útil para la industria y el trabajo, el segundo es un habitante peligroso en cualquier parte. Ocurre al juez, porque tiene el instinto de creer que le harán justicia de miedo, y hay ejemplos, si no se la hacen se venga, hiere o mata. El primero compone la masa social argentina; el segundo va desapareciendo."

Ao lermos essa diferenciação, fica claro que Arregui quer diferenciar o "gaucho" dos primeiros tempos daquele "gaucho-paisano", ou seja, peão, "bucha de canhão", fruto das transformações trazidas pela "civilização". 
Nessa perspectiva, o ensaio "Literatura y bota de potro" aponta certos aspectos da literatura gauchesca:

“(...) esa literatura tuvo en el tiempo diversas entonaciones, pero aquí sólo tomaremos en cuenta una o dos de ellas."

Arregui então evidencia que no Uruguai houve alguém que se chamou Domingo Ordoñana e outro alguém que se chamou Lorenzo Latorre que exerceu o comando como presidente do país durante quatro anos e três dias (1876 a 1880). Ordoñana foi o ideólogo e Latorre foi o executor de um projeto de alambramento do campo que consolidou o regime vigente da propriedade de terra, o que eliminou o "minifundista" e iniciou sua concentração nos subúrbios dos povoados das cidades do interior e em Montevidéu, dando origem aos "rancheríos".

É o próprio Arregui que, em nota de rodapé, acusa a assombrosa arbitrariedade na repartição das terras durante o governo de Latorre:

"Son assombrosas las cifras de postes de flandubay y de quilos de alambre importados durante su gobierno. El alambrado rubicó la derrota del gaucho, y el odio al alambrado persistió en los sótanos, nada hondos, del alma del vencido y de sus hijos, inclusive de los muchos que abrazaron - es un decir - el oficio de alambradores. Me contaba el más viejo de mis tíos que cuando de las guerras civiles de 97 y del 04 las partidas de jinetes derstrozaban alambrados para acortar distancias y para utilizar postes y piques como leña de fogones, pero asimismo, muchísimas veces, "de puro dañinos, por joder nomás."

Nesse contexto do predomínio das cercas, os donos da terra afirmavam que "ya no hay gente compadre". Compadre, nesse caso, significa gente arrogante e indócil, o que remete ao "gaucho". Segundo Arregui, o "gaucho" "con el espinazo quebrado" converteu-se para galgar a sempre fácil nostalgia, que tem "muchísimo que ver com el conservatismo latifundista"

Nesse ponto, fica claro que a ira de Arregui deposita-se não no "gaucho" dos primitivos tempos, mas na figura de literatos, "muchos de ellos hijos de estancieiros o estancieros ellos mismos", que se apossaram da figura do "homem livre dos pampas" e pregaram a "gauchofilia nostálgica e derechista", para escamotear a realidade de um regime "mestizo de feudalismo e capitalismo (mal nacido y peor crecido capitalismo dependiente que quedo establecido como um monstruo natural)." Contudo, o escritor faz 
um comentário para observar que essa "gauchofilia nostálgica" não vale para a poesia gauchesca anterior, fundada no início do século por Bartolomé Hidalgo e toda sua intenção política "de signo antiespañol, revolucionário."

Também desconta da lista de escritores "gauchófilos" Javier de Viana, "cuya postura de "escritor verista asumida con honestidad le hizo pintar com tinta agriada al gaucho en vias de ser triturado".

Ligia Chiappini, ao confrontar a literatura de Javier de Viana (1868-1926) com a de Simões Lopes Neto, afirma que esse escritor uruguaio, assim como Lopes Neto, engajou-se politicamente em causas nacionais. "Tinha um projeto literário-político-pedagógico, de influir, pela sua literatura, preservando e divulgando a memória cultural do pampa do Uruguai para as novas gerações. Colocou suas crônicas e contos a serviço do povo mais pobre, que sofria com a modernização das estâncias, transformadas em fazenda, com o processo de urbanização, que ia deixando à margem o gaúcho pobre, antes tido como herói e defensor da Pátria, nas lutas de fronteira e, agora, transformado em bandido, rebelde, contrabandista, marginal ou submetido ao trabalho mais disciplinado das fazendas, como agregado ou como sem terra, quando não expulso para as periferias das cidades."

Em contraste com a literatura política e social de Javier de Viana, está a literatura de Elías Regules. Dele, declara Arregui:

"La primitiva gauchesca había sido política; ésta cuyo estandarte levanta con aparatosidad un mucho demagógico el Dr. Regules se pretende apolítica, inadvertiendo (o tal vez sabiéndolo bien) que el apoliticismo es una clara actitud política de conformismo ante la estructuración social vigente. En sua linda nota sobre Regules el siempre bien informado Angel Rama nos cuenta que la recién fundada "Sociedad Criolla" celebraba almuerzos criollazos - con mate amargo, banderas, juramentos solemnes, pericón, asado con cuero , etc. - en una quinta montevideana en cuyos árboles colgaban cartelitos en donde se leía "Está prohibido hablar de política y de religión".

(...)

Esta gauchesca un tanto decorativa, vista con simpatía levísima burlona por los bien-pensantes urbanos y aplaudida por lo estancieril (entendiendo por tal no sólo el pensar y el sentir propios de los estancieros sino también la impronta de éstos, como clase dominante, sobre los sentires de otras capas sociales), no pudo no tener su lado carnavalesco. En ella, además, era evidente el escamoteo: cantos al gaucho de antes y elegías a taperas concurrían a sustituir la cruda realidad de los rancheríos marginales que se llaman pueblos de ratas - porque ya por entonces, 
como consecuencia del cercamiento de los campos, "ha comenzado para una parte de la población del país esa era de pobreza cuyas referencias conocían los hombres ilustrados por el trato de los publicistas europeos", como dice Bauzá en una memoria presentada en 1892, o sea dos años antes de la fundación de la "Sociedad Criolla".

Interessante observar que Mario Arregui também nomeia de gauchesca ao conjunto de literatura do Uruguai, pós Martín Fierro, que tem como protagonista tanto o "paisano-gaucho" no seu cotidiano de marginalização, como na literatura de Viana, quanto àquela que retoma a figura do "gaucho", exaltando seus atributos, para escamotear a realidade da miséria, como a literatura de Regules.

Já Graciela Mántaras Loedel e Jorge Arbeleche nomeiam essa literatura de Regules de "criollista". Eles afirmam que a "Cuenca Platense", lugar de origem de um tipo humano peculiar - o "gaucho" - proporcionou uma literatura a ele vinculada: a literatura gauchesca. Ela produziu uma obra de valor relevante: o Martín Fierro, de José Hernández. Exterminado o "gaucho", os novos tipos rurais que apareceram, como o peão do campo, o pequeno e médio agricultor, o "chacarero", encontraram seu lugar literário em uma literatura "campesina o campera o rural" que recebeu denominações de "criollista o criolla". Essa literatura foi abundante em cultores e em títulos, fortemente ideologizada desde suas origens (a inicial ideologia combativa e militante logo prestou serviços às classes dominantes), de ampla difusão popular sempre, mas, muitas vezes, manteve-se distante dos autênticos valores estéticos que lhe permitissem transcender as circunstâncias.

Afirmam, ainda, que, próximos aos anos 1920, a "poesia criollista" com mais influência foi a de Elias Regules (1861-1929). O seu livro Versos Criollos, lançado pela primeira vez em 1894, é ampliado em 1900 e se encontra na $7^{\text {a }}$ edição em 1922, o que demonstra a ampla circulação de sua literatura. Em 1924, é lançado Mi Pago. Regules escreveu para manter os privilégios dos estancieiros, que já haviam perdido seu poder político desde os governos de José Battle y Ordóñez, que exerceu duas presidências no Uruguai (1903-1907 e 1911-1915):

"Regules ha sido entre nosotros el "inventor de la tradición", como ha visto y señalado Angel Rama - dio voz literaria a "las classes rurales" en protesta contra el aluvión inmigratorio, lo que visualizaron como la 
extrajerización del país; en resguardo ante la defensa batllista de los marginados; ante sus arrestos verbales contra el latifundio y el ausentismo de los patrones rurales; la política fiscal que procuró desestimular-los; la política agrarista que procuró colonizar la campaña y hacer de ella el asiento de los agricultores."

O "batllismo" aproveitou a modernização latorrista e se apoiou nas classes médias em crescimento, por obra da forte imigração e urbanização, para executar seu projeto de governo. Queria uma sociedade uruguaia alfabetizada e crescentemente educada. Era sensível aos problemas dos indefesos (trabalhadores, idosos, mulheres, crianças), com uma altíssima valorização da educação como meio de ascenção social. O Estado se ocupava da saúde, educação, das atividades econômicas. Era aberto ao resto do mundo, independente, democrático. Porém, ignorava o que Artigas mencionou há cem anos: sem redividir a propriedade, fomentando o poder de consumo da massa de consumidores, ficam estagnadas as possibilidades de qualquer desenvolvimento econômico sério.

Na verdade, "la política econômica de Battle no logró ningún cambio importante en la estructura econômica del país". Dessa forma, "en un país fundamentalmente agropecuario, con fuerte propensión monocultora, todo proceso de reorganización de la economia con vistas a un desarrollo independiente, tenía que tener como base una profunda Reforma Agraria. El batllismo eludió ese camino, intentó el imposible de una estructuración nacional dejando de lado el campo donde quedaron intactos los sistemas de producción y las relaciones de propiedad dominantes en los albores del siglo (...) se eludió la Reforma Agraria mediante un colosal subsidio estatal que sostuvo a los desplazados por el latifundio y la pauperización rural, con la multiplicación de actividades urbanas y especialmente con la creación de una enorme burocracia (...) de este modo el país se devoró a si mismo." Recardo Martínez Ces argumenta que " el battlismo fue una repuesta eficaz a la problemática de la época, al Uruguay de la inmigración y del 'progresso inglés'. Más tarde dejará de servir, pues jamás se animó a merterle mano a la estructura del país.

Dentro desse contexto do Uruguai das duas primeiras décadas do século $X X$, o que interessa a escritores como Regules é "ser um defensor de las más auténticas tradiciones nacionales ante los embates de la extranjerización." Contudo, Cayota argumeta que a causa da existência da pobreza rural e da migração interna do campo à 
cidade não reside na chegada dos imigrantes nem na submissão do campo à cidade. A verdadeira causa "es el límite, la frontera a todo crecimiento económico posible que dimana de la propia estructura de la tenencia y la explotación de la tierra en el país." Sobre Regules conclui:

"Su poesía y su tradicionalismo surgen de las mismas fuentes: sua añoranza de un pasado personal que él quiere envertir en añoranza de todo un país; su deseo de trasladar formas de vida de otra época a la sociedad de su tempo(...) El 'tradicionalismo' del autor (...) no es tal, sino que es conservadorismo, es decir, intento de mantener vivo lo que ya no existe y que, como en el mito griego, sólo podrá renacer con una vida distinta, nueva en la que estén implícitas las viejas pautas culturales. Su obra tampoco es reivindicadora del hombre de campo, pues olvida sus más entrañables y duras realidades y se reduce al esquematismo del estereotipo".

O que se vislumbra é o desejo de Regules manter o latifúndio, ligado à criação de gado, intacto, ou seja, ele teme que o Uruguai torne-se "un país agrícola como habían soñado los reformistas del battlismo"; ocorre, dessa forma, o enfretamento do "pastor e do labrador”. Porém “La Asociación Rural primero, la Federación Rural después (el más poderoso grupo de presión a lo largo de toda nuestra historia), representaron siempre a la alta clase rural ganadera, no a los agricultores, aunque dijeran representarlos. El exterminio del gaucho primero, la expulsión de brazos luego, el crecimento del pobrerio rural siempre, fue justamente obra del sistema de tenencia y explotación de la tierra que defendieron a ultranza los grandes ganaderos."

Pablo Rocca nomeia essa literatura de 20 do Uruguai e o que vem depois dela de "posgauchesca", para evitar a imprecisão de termos como "criollista". Para ele, a gauchesca tem relação com a obra de Hidalgo, Ascasubi, Hernández, Lussich. Depois disso, houve, nos anos 1900,uma literatura rural "culta" de Acevedo Díaz, Javier de Viana, Reyles. Já Elias Regules é denominado por Rocca de "posgauchesco", termo também atribuído para designar Fernán Silva Valdés e Pedro Leandro Ipuche que muitos também chamaram de "nativistas":

"Es cierto que algunos, como Fernán Silva Valdés o Ipuche, redujeron al máximo, al menos en su poesía, las hipotéticas peculiaridades del habla criolla, para expresar, en un castellano neutro o académico y en acuerdo 
a los nuevos aportes de la vanguardia, los viejos temas del medio campero. A esto le llamaron, ellos mismos, "nativismo" o incluso "gauchismo cósmico.(...) El "nativismo" se trató de pequeños ajustes a los motivos ya clássicos. Por eso, en medio de las transformaciones sociales y políticas más fuertes (crecimento de Montevideo y las capitales departamentales, derrota del país rural luego de la guerra civil de 1904, industrialización progresiva, triunfo del proyecto batllista), buena parte de la literatura pós-gauchesca puede ser observada como una última resistencia a la modernización, que no deja de mostrar cierto reflejo conservador."

Pablo Rocca, dessa maneira, afirma que o "nativismo" tentou uma renovação, porém não a alcançou e pouco se diferencia da "posgauchesca" ou "criollismo" de um Regules. Este também é o ponto de vista de Mario Arregui, como observaremos mais adiante.

Rocca constata ainda que a geração de 45 dividiu-se em duas grandes vertentes. 0 primeiro grupo era formado por Emir Rodríguez Monegal, Mario Benedetti, que tomaram o poder do semanário Marcha e continuaram a demolição de Onetti, quem, como já dito, atirou a primeira pedra contra o "rancho criollo". Era um grupo unido pela desconfiança contra o realismo rural das décadas anteriores. Combatia a identificação do nacional com o rural; desse modo, proporcionou uma abertura à cidade como tema, trazendo a novidade técnica e cosmopolita. Esse grupo percebeu que apesar de a literatura de Arregui estar ligada, de certa forma, à tradição rural, assim como a literatura de Francisco Espínola, transcendia o "costumbrismo" (descrição do ambiente e da paisagem), porque tinha a capacidade de partir do local para representar "la dinâmica de las almas". Também apontaram na literatura de Arregui uma renovação lingüística e técnica parecida com a de Borges. Para esse grupo, com a exceção de Espínola, Arregui, Morosoli, Enrique Amorim e Julio C. da Rosa, os demais eram vistos como discípulos praticamente fiéis a Javier de Viana e Eduardo Acevedo Díaz.

O segundo grupo, segundo Rocca, numa relação de oposição, atrincheirou-se atrás do argumento da falsa oposição entre campo e cidade, mas tendeu a relacionar amparada em uma noção de cunho idealista e romântica - o "ser nacional" com o "criollo", deixando de abordar os problemas técnicos, admitindo o realismo usual do século XIX ou o "realismo poético", como solução estética. Essa tendência esteve representada na revista Asir e, mais tarde, nas páginas literárias de El Ciudadano y El 
País e encontrou em Arturo Visca e Domingo L. Bordoli seus exercitantes mais ativos por defenderem a validade dessa literatura a que Visca chamou de "criollista".

Arregui quando afirma não ser um criollista parece que assume a posição do grupo de Mario Benedetti, já que visa romper com o "canon realista". Além disso, repudiava a "gauchesca decorativa" das primeiras décadas do século XX, também denominada por outros críticos de "criollismo", literatura que serve a uma ideologia clara. Ser criollista, portanto, para Arregui é escrever uma literatura que não apresenta renovação estética e está vinculada à ideologia dos detentores da terra, como as obras de Regules. Sobre esse tipo de literatura que também possui sua conotação "nativista", Mario Arregui afirma:

"Lo que no ha muerto es la narrativa criollista, que también posee sua continuación nativista. Hay un puñado de narradores que insisten en apresar lo nuestro, eso que no se sabe bien qué es pero siempre se imbrica, a juzgar por los frutos, con lo rural y lo pueblerino, con lo cachivaches y los espantapájaros de la tradición, con un español semidialectal... Son, en general, montevideanos por adopción que se masturban con una nostalgia casi lírica de sus años pre-montevideanos. Trabajan recurrentemente un corto número de temas, llegan poco menos a venerar ciertos rostros del sub-desarrollo y, casi sempre, pueblan sus narraciones de seres humildes - almas simples o almitas - a los que miran con ojos paternalistas y como si de algún modo planearan sobre ellos. A veces fingen ser más incultos de lo que en realidad son, y suelen creer que pobreza material, pobreza de espíritu y bondad en profundidad son las tres hojas hermanadas de una planta de trébol que rara vez tiene cuatro... Este regionalismo departamental (departamental en más de un sentido) los limita irremediablemente."

O crítico, Wilfredo Penco, em 1979, faz-lhe a seguinte questão: "por qué há declarado en más de una oportunidad que usted no es un escritor criollista?" Arregui responde:

"Para calificar a un cuento como criollista no alcanza con que él tenga como personajes hombres del campo y como background una zona rural o una estancia. Falta, en primera instancia, algo que es básico: una voluntad de criolledad y su cosmovisión, donde lo criollo sea un heróe positivo, digamos, o un cardinal valor de sostén. Nada parecido anda por mi literatura, creo." 
A literatura, para ele, deve ser "un sistema de exploraciones y sondeos de la condición humana y un linguage para hondas comunicaciones. (...) O sea tambíen que su función (una de sus funciones pero sin duda la de mayor cuantía) sería la de colaborar con nosotros en el planteo siempre inicial de la empresa siempre continua de ser hombres: averiguarmos y comunicarnos. (...) El arte literario sigue siendo el que mejor cumple la misión de modificar las relaciones del ser humano con lo que es, con lo que cree ser, con lo que quiere ser... y, en consecuencia, con los otros hombres. Ya dijo alguien que los hombres son algo así como el caldo de cultivo de cada hombre, ya dijo Nietzsche que un hombre en soledad tiende a disgregarse. (...) La literatura es palabra artística de un vastísimo mundo re creado cuyos sortilegios nos aluden y conmueven, y gracias a ella, por una suerte de magia simpatica, nuestras experiencias reales se tornan más válidas, más nuestras."

Visitar e revisitar a condição humana, por meio de uma linguagem que possibilite a humanização, no sentido de levar o homem a se indagar sobre sua existência e sobre a do outro dentro da sociedade, porque a construção do equilíbrio individual, depende do bem-estar do todo, é o objetivo da literatura de Arregui. Esse escritor, por meio da formulação estética, procura evidenciar os mecanismos indesejáveis, como a violência nas suas mais variadas formas, para clarear os obscuros caminhos a que o homem está submetido.

De maneira geral, todos os contos de Arregui visam a esse objetivo, mas a meta é analisar aqueles contos onde o "gaucho" e o "paisano-gaucho", num contexto fronteiriço, num contexto assolado por guerras, por perseguições, por marginalização, aparecem como protagonista. Antes, adensaremos uma análise das narrativas que o próprio escritor nomeia como "contos de fogão".

\section{3- O "cuento de fogón"}

Arregui, em Ramos Generales, discute a diferença entre a literatura gauchesca dos 900 e das primeiras décadas do século XX e os "cuentos de fogón".

A literatura gauchesca, segundo Arregui, não é obra de "gauchos", já que por trás de toda página "profesionalmente agauchada" encontra-se sempre um escritor 'mais ou 
menos' culto disfarçado de "crioyo e de ley". Para o escritor uruguaio, existe uma flagrante inautenticidade nesse tipo de literatura, mas, assim mesmo, seria desacertado desqualificar por isso o gênero em si: ao final das contas, todo gênero literário é artificial e, por outro lado, a inautenticidade não tem impedido - inclusive, às vezes, pode ter propiciado - a criação de textos memoráveis. Contudo, devemos reconhecer que o outro, o autêntico, é o "cuento de fógon" (o que é literatura ou se assemelha , não o que parece com História ou periodismo):

"El fogón es el lugar en donde los hombres del campo se reúnen a la espera de la hora de salir a trabajar, o de que esté a punto el puchero o el guiso para el almuerzo, o de que termine de dorarse el asado para la cena. Hay fuego, mate, tabao, proseo... Hay calor humano.

(...)

Cuatro o cinco o más hombres "como adorando el fogón" son una unidad, un grupo. Sienten y reaccionan en tanto que grupo. Y como tal suelen tener deseos que no tendrían si sólo fueran individualidades sumadadas. $Y$ uno de esos deseos- consciente o secreto, formulado o no - puede ser el de oír un cuento bien contado. $Y$ el cuento, entonces, entra naturalmente en escena - viejo como la voz, hermano de los primero fuegos que hombres primigenios domesticaron.

Entra como en puntas de pies y como si, con toda la paciencia delmundo, hubiera estado a la orden desde siempre; y se desenrosca como sabiendo que ocupa un tiempo de espera, casi puro, y sin abjurar sus fraternidades con los cabrilleos de las llamas y los desperezos del humo. Y su narrador, su ocasional narrador, cumple una función análoga - pero más espontánea y sin duda más civil, más atenciosa - a del escritor que, como es común decir, cultiva la literatura."

No livro El Narrador de 1972 "la pieza inicial, poco más que una anécdota", também se intitula "El narrador". Ela apresenta uma "declaración de ciertas vagas posiciones estéticas" que o narrador de um "cuento de fogón", segundo Arregui, deve assumir. "El narrador" traz comentários sobre um velho alambrador que, nos anos 1960, contava "en el fogón" episódios da guerras civis de 1897 e 1904, e era escutado pelos peões, pelos filhos dos patrão. Mario Arregui conclui como era sua narração:

"El alambrador narraba bien. Marcando con una sonrisa las necesarias salvedades, podríamos dicer que era un clásico. Nunca se colocaba en posición de héroe o de actor importante; nunca decía "yo" y casi nunca testimoniaba como testigo presencial o, por lo menos, demasiado inmediato. Reconstruía y mostraba los hechos con el ánimo y desde los 
puntos de mira de un observador un tanto abstracto, bastante impasible, muy naturalmente ubicuo o semi ubicuo... Contaba como alguien que había visto y sabido todo pero que tenía (o había tenido) la virtud de olvidar e recordar de acuerdo con las leyes universales del olvido y la memoria. Sus relatos eran lineales y límpidos, sin trampas ni tecniquerías, conducidos con dominio instintivo del arte de narrar (ese arte que es más común de lo que los escritores, los profesores y los críticos literarios suelen creer). Y no se confinaba en la épica: la guerra era en sus labios las horas de combate y lo que ellas implicaban o podían implicar ( el cuerpo ofrecido al peligro como si no fuera del todo propio, la intención de matar hombres asumida de la manera en que se asume una tarea, la muerte rondando a cada uno lo mismo que una multiplicada mosca verde llamada por el olor del coraje, el miedo sacando de pronto sus cabecitas de víbora por imprevistas grietas del alma...); pero era también , y más todavía, la vida libre y casi feral en los acampamentos, las matrereadas un mucho lúdicas, las carreras de piojos en las hojas de facones en las caronas, las marchas y contramarchas en caballadas agotadas, las diabluras como actos gratuitos, la dificultades para conseguir un puñado de sal...

\section{(...)}

Por su boca contaban sus abuelos, su padre, sus tíos y muchos otros hombres muertos de su linaje y su raza. Y finalmente podía (y debía) hacer puntualizado con algún énfasis que no era él un mentiroso sino algo muy diferente, algo un poco mágico y un pouquito sagrado: un narrador."

É interesante observar que Arregui nega a "gauchesca decorativa", mas tem necessidade de focar, de uma maneira distinta, o ser que povoou essa literatura. Ele se sente atraído pelas narrativas que colocam a vida do "gaucho" em cena, no eterno embate nas guerras de fronteiras, nas guerras civis. Considera autêntico o comportamento do narrador e do interlocutor do "cuento de fogón", que, embora, muitas vezes, não tenham participado desses embates, vivenciam-nos quando a memória é verbalizada.

Esses "relatos" funcionam como um resgate da figura do "gaucho", desprovido de épica e heroicidade. Ele é um ser que convive com a miséria das guerras, com "a intenção de matar homens como uma tarefa assumida", sem a mitificação de sua coragem e bravura.

Arregui, então, ao escutar esses "cuentos de fogón" procura reproduzi-los. Em sua literatura, segundo ele, há três narrativas que procuram demonstrar o que foi esse gênero: "Un cuento de fogón", "Contaba don Cláudio", "El caballo piadoso". Essas, 
juntamente com os outros contos, traduzidos por Faraco, que privilegiam os eternos embates do "gaucho", podem oferecer um panorama da busca de um "gaucho" mais "autêntico", retomado nos contos do escritor uruguaio de tempos em tempos.

\section{1- "Un cuento de fogón"}

"Un cuento de fogón" encontra-se no terceiro livro de Arregui, La sed y el agua (1969). Arregui afirma no prólogo:

“ UN CUENTO DE FOGÓN es un juego, casi una broma. Recogí su tema en un fogón de troperos. Muchos temas semejantes (España, todos lo sabemos, nos colonizó con hombres medievales) subsisten todavía, aunque enxangües, en la literatura oral de los fogones; en general son muy pobres, inservibles; éste debe ser uno de los mejores, o por lo menos es, me parece, el mejor de los que he podido oír. Lo escribí con la necesaria, imprescindible dosis de tinta lúdica. Se ha dicho que suelo jugar demasiado en mis cuentos; tal vez sea verdad. Pero yo diría, a mi vez, que no está demostrado que el escritor deba escribir siempre "vestido de luto" y que tengo la pretensión de que la solemnidad (tan parecida a la bobería solemne!) no sea uno de mis rasgos más típicos."

O que Arregui denomina de "cuento de fogón" aproxima-se ao que denominamos de "caso". Segundo Arregui, "en español, relato y cuento serían o fueron sinónimos, pero el uso está estableciendo una diferencia. Relatar una cosa és contar con probidad algo que pasó o pudo haber pasado. Contar algo es lo mismo. Pero hacer un cuento tiene una intención artística mayor, más literaria, más en los postulados de Poe (Borges dice: “... el cuento, un premeditado objeto verbal, provisto de un principio, un medio y un fin, como aristotélicamente quería Edgar Allan Poe...") . La diferencia es muy sutil . El cuento no es sólo contar sino también armar una estructura, es algo menos natural que relatar. El relato es más laxo, menos intenso, que el cuento. La diferencia es muy sutil y difícil." Assim, a palavra "relato" em espanhol corresponde ao que denominamos "caso", narração que traz acontecimentos resgatados pela memória popular, tratado por Arregui como "un género lindo y menor", gênero que se aproxima ao conto, porém é menos estruturado, mais livre, mais natural; daí surge a autenticidade que Arregui afirma que só os "cuentos" ou "relatos de fogón" possuem. 
Por outro lado, Angél Rama sustentou a tese de que os contos de Arregui são dominados por uma busca de essências. Porém em muitos deles, a partir dos anos 1960, há "una nueva mirada, más en superfície ya que no superficial. El autor, tan apegado a temas de grave dramatismo, se consintió una vaga, humorística indulgencia por los hombres, sus juegos, sus errores, su vivir menudo. Es signo, en muchos creadores, de un proceso de maduración que viene acompañado de la disolución de la urgente problemática íntima y conduce a una mirada panorámica sobre la sociedad en que vive."

Nesse sentido, em vários contos de Arregui, ecoa a necessidade de evidenciar que muito da cultura uruguaia nasce com o "gaucho". Mas Arregui nega um certo tipo de "criollismo", porque visa retomar essa figura de maneira menos mitificada. Assim, o "cuento de fogón" foi uma das formas que encontrou para alcançar esse objetivo. No entanto, o escritor vai se apropriar desse gênero "lindo y menor" e estabelecer características particulares a ele.

"Un cuento de fogón", por exemplo, trata de uma temática simples: um tropeiro perde seus cavalos e para encontrá-los busca a ajuda de uma vidente que indica o local onde os animais estavam.

Um narrador onisciente conta que Nicodemo Carrión, tropeiro de profissão, passa a noite bebendo e jogando truco "y perdiendo al monte los no muchos pesos que tenía el cinto". Ao amanhecer, quando decide ir embora, percebe que os cavalos haviam sumido.

Ao não ter sucesso na sua busca pelos animais desaparecidos, resolve consultar uma curandeira e adivinha, Dona Viviana, para ter conhecimento do rumo dos cavalos, pois Maria, mulher de Nicodemo, afirmara que aquele sumiço só poderia ser "cosa de brujería".

Nesse momento, percebe-se que mesmo que Arregui repudie as superstições, que, segundo ele, marcaram a vida do "gaucho" dos primeiros tempos, é impossível fugir delas na zona rural uruguaia, pois afinal a Espanha colonizou o Uruguai com homens medievais, cujo mundo "estaba como acribillado y aun desfondado por la posibilidad de lo sobrenatural, y era mucho más rico - muncho más hondo y nocturno, sobre todo - que este mundo de hoy, sin sirenas y otros prodigios." É nítido que Arregui faz questão de explicar todas os componentes "criollos" que adiciona à sua escrita, no caso aqui a 
superstição, para diferenciá-la da "gauchesca decorativa", cuja literatura era povoada por "gauchos" supersticiosos.

Outro aspecto que chama a atenção é a descrição da velha bruxa:

"La cara infinitamente arrugada de la vieja no tenía otra raza que la extrema vejez; sin embargo, la nariz aplastada por donde expelía el humo muy blanco del tabaco brasilero, contrabandeado, revelaba una dosis grande de antigua sangre negra o india."

É uma descrição que evidencia o contato entre uruguaios e brasileiros que se manifesta por meio do contrabando de mercadorias. É uma descrição que evidencia a miscigenação do povo uruguaio, não formado por uma única raça, a do "gaucho", mas da mistura de várias, como o índio e o negro. Essas pequenas pinceladas num amplo painel vão compondo a "mirada panoramica" de que fala Angel Rama sobre a obra de Arregui. Nicodemo:

É, por sua vez, o narrador onisciente que mostra o olhar "panorâmico" de

"Vio novillos con reluciente peleche de primavera y gordura de eunucos; vio vacas y ovejas que pastaban gregariamente em las ladferas y los bajos de potreros bastante quebrados; vio toros que, um poço dissidentes de los rodeos, ruminaban esperando el estro de sus hembras; vio un hermoso potro colorado - enardecido su color por el sol matinal; dejado para padrillo o simplemente todavía sin castrar-, que se precipitó hacia él en una anhelosa averiguación del sexo del sabino y lo escoltó alambrado por medio y galopó repetidas veces en círculos y volvió cada vez, lanzando relinchos de reclamo y otros que quizá fueran puteadas a los alambradores implícitos, a golpearse contra los piques y los postes y a hacer bordonear los alambres. (no había visto aún y no vio, y no vería hasta cerca del mediodía, un ser humano cualquiera)."

A descrição dos animais e da paisagem, em momento algum, é nostálgica. $\mathrm{Na}$ verdade, mais uma vez, o narrador onisciente culto, que não cede a voz ao "gaucho" mas que conhece muito bem suas aflições, aproveita para criticar os alambrados e o despovoamento das terras, o que demarca a extensão dos latifúndios.

Embora a crítica esteja presente, a psicologia de Nicodemo é rasa; não é um homem afoito a grandes indagações sobre a sua existência. Mas uma possível densidade 
psicológica é recuperada por um outro tipo de narrador que se encarrega do sentir alheio por uma versão mais profunda diante do corriqueiro mundo de Nicodemo:

"Había nacido en el povoado y había vivido sus casi cincuenta años en medio de lo que veía y estaba hecho a la medida de ello; ni del modo más larvario o rudimental podía pensar en la soledad íntima y perfecta y oscuramente enemiga del campo sólo campo, ni en la minúscula ancla en la eternidad que es un animal comiendo en un tiempo que para nosotros significa horas y para él no pasa, ni en la paciencia taimada del toro y el ímpetu inocente de un potro entero que concibe la posibilidad de la cópula, ni el atroz vejamen que constituye la castración y el algo - mucho - de sacerdote de un culto malvado que adquiere un hombre en acto de castrar, ni en cómo se diluye la idea de Dios en una Naturaleza rica y elemental, ni en otras varias cosas más o menos como éstas."

Assim, a princípio, esse conto parece retomar o modelo tradicional do realismo do início do século $X X$, a que já referimos. Mas, fica claro que Arregui visa romper com ele, ao menos em relação ao narrador, pois não há a presença somente de um narrador onisciente, que, embora culto, evidencia "o sentir", sem "tecniquería" de Nicodemo, e sim a de um outro que é o próprio Arregui, que se encarrega de recuperar os sentimentos daquele homem por meio de uma versão mais intimista.

No final do conto, o tropeiro encontra seus cavalos exatamente no lugar indicado pela vidente. Apesar de o enredo ser simples, o que chama a atenção é a técnica narrativa que mistura a voz de um narrador onisciente e de um narrador-autor. Há ainda a caracterização dos personagens que compõem tipos "autênticos" do Uruguai. Os costumes, como cevar o mate, jogar truco são rememorados como uma espécie de resgate da cultura uruguaia.

\section{2- "Contaba Don Cláudio"}

Mas ao rememorar um tempo de guerras, de valentias, de fraquezas, Arregui não cede a voz a um personagem, não interioriza, em nenhum momento, o foco narrativo, embora relembre muitas das histórias do "gaucho" por meio da figura de don Claudio.

No livro El Narrador, Arregui publica os "relatos" de don Claudio González, "un criollo que dedicó buena parte de sus días a contar una suerte de autobiografía 
fantástica, y cuyos cuentos, a muchos años de su muerte, siguem vivitos y coleando en los fogones del departamento de Flores."

"Contaba Don Claudio", além de conter os "relatos" desse "genuino criollo", possui, no início, uma espécie de ensaio, onde Arregui retoma suas observações a respeito do embrião da contística uruguaia, que, segundo ele, nasceu "en los fogones gauchos". E que temas manejaram aqueles contistas que vestiam "chiripá y calzaban, cuando calzaban algo, botas de potro? No es mucho lo que sabemos, porque quienes averiguaron al gaucho atendieron más a lo que él canto que a lo que él conto; pero se puede colegir sin mayores riesgos (porque, entre otras cosas, la literatura de los fogones no há muerto del todo) que los temas fueron, por un lado, de testimonio, de decir com relativa probidad "pasó así", y por outro, de exageraciones desaforadas, de fantasias tal vez creídas o semi-creídas, de mentiras químicamente puras... Éstos que de um modo u outro no respetan la realidad son, al fin de cuentas, los que importan."

Depois dessas observações, Arregui descreve don Claudio como uma figura que motivava "bromas", pois nunca poderia ter a idade dos casos de guerra que dizia ter feito parte. Ele era "alto y fuerte, muy huesudo, de pelo negro y encrespado, tez cetrina o "color del país", ojos grandes y poco saltones y (segundo dijo su hija) mucho más clarosde lo que uno puede apreciar en las fotos; era serio, austero, respetuoso y partidário del respeto y "pronto de gênio" cuando husmeaba irrespeto; era muy cuidadoso con su familia, muy sociable y bastante ceremonioso en el trato; le gustaba vestir bien ( dentro de un estilo apaisanado, claro), le gustava cocinar e invitar a comer, le gustaban las reuniones, los casorios, los bautismos; tenía la voz grave y criolla y pausada, tenía manos grandes y asombrosamente elocuentes; nunca fumó, ni tomó, supo trabajar cuando era necesario, nunca faltó a sua palabra y, aparte de sus cuentos, nunca mintió..."

Don Claudio compõe o tipo de homem mestiço, o "paisano-gaucho", o nativo que habita a Campanha uruguaia e está longe de ter a heroicidade do "gaucho" da literatura do início do século XX. Embora Arregui aprecie os casos que não respeitam a realidade, o que proporciona um dos ingredientes da literatura, são esses mesmos casos do imaginário popular que, embora exagerados, trazem à tona as situações limites a que o homem uruguaio, que habita o campo ou os pequenos povoados, está submetido. 
Arregui não cede a voz ao "autentico criollo", quando transmite seus casos. Ele intermedeia a narração com frases como "contaba don Claudio que una mañana...". O narrador-autor em $3^{a}$ pessoa apossa-se dos casos de don Claudio e, embora tente manter a possível visão desse "genuino criollo", artificializa sua voz, pois ela passa pelo seu filtro interpretativo.

Don Claudio costumava contar a história "de una estância donde todo era gigantesco y los aviones pasaban por entre los hilos de los alambrados". Note-se que esse gigantesco refere-se aos grandes latifúndios e, mais uma vez, surge a presença das cercas, que mudaram a vida do homem do campo. Os problemas sociais e econômicos do Uruguai contagiam o imaginário popular.

Contava o caso "de su facón tan filoso que cortó no sólo el asado sino también el plato y la mesa y hasta un pobre gato que tuvo la mala suerte de pasar por debajo." Nesse caso é a faca do "gaucho", instrumento de sua indumentária que ganha destaque. Impossível "imaginar" um "gaucho" sem uma faca à cintura. Assim, numa espécie de fusão, as características dos "gauchos" dos primórdios misturam-se com as dos descendentes desses para povoar os "relatos".

E as valentias da guerra? Don Claudio "sirvió (en filas coloradas) em todas las guerras civiles que hubo en este país y en otras que no hubo o de las que solamente él tuvo noticias. Sus aventuras bélicas no fueron, por lo que sabemos, muy heróicas ni muy cruentas; nunca dijo haber matado a nadie, nunca se jactó de haber encabezado una carga a lanza, nunca habló de sangre con es fruición malsana con que se suele hablar de sangue... De todos modos, cosechó algunas heridas cuyas cicatricaes casi siempre de olvidaba de mostrar (“... y mañana les muestro la cicatriz que tengo”, decía, y continuaba su relato). El percance más serio parece haber sido la pérdida de un ojo, felizmente recuperado."

Embora contagiado pela figura do "gaucho-héroe", don Claudio endossa sua valentia, destreza por meio de um tom equilibrado, sem exageros de bravura. As guerras contagiam sua memória, mas há a narração de um heroísmo parcial; e o que resta disso tudo são cicatrizes, vestígios de feridas, que conservam impressões duradouras de situações adversas a serem questionadas. 
Don Claudio retém a memória coletiva de um povo que foi submetido a guerras de fronteiras, a guerras civis, que serviu de bucha de canhão e, tal qual Martín Fierro, vê o índio como um inimigo, visão não compartilhada por Arregui:

"Dicen los libros que en este país los índios fueron exterminados o puestos fuera de circulación hace muchísimos años. (...) Estos detalles de mera historia no impidieron a don Claudio tener un problema con ellos, dedicarles un capítulo de su larga y riquísima autobiografía imaginaria.

Contaba don Claudio que cuatro arborígenes ("indios sanguinarios", decía recordando a Martín Fierro) le tendieron un día una emboscada. Él no sabía leer pero lo había oído muchas veces y podía citar de memoria "el indio es de parecer/ que matar siempre se debe,/ pues la sangre que no bebe/ le gusta verla correr", y también: "Odia de muerte al cristiano, / hace guerra sin cuartel; / para matar es sin yel"... Aunque la terroista imagen del indio que Hernández pone en boca de Fierro era también de algún modo suya, don Claudio no sintió miedo: montaba esa mañana un extraordinario tostado patas blancas."

Ainda que, para Arregui, o índio não seja um sanguinário, é impossível negar a amplitude e a identificação do Pampa Uruguaio com a obra Martín Fierro, cujos versos eram recitados, aprendidos por quem sabia ou não sabia ler e "pintavam" o índio de maneira negativa.

Mas o "caso" que don Claudio conta desses "infieles", os quatro índios que o perseguiam não acaba em sangue. Com o seu cavalo "tostado", ele consegue fugir dos arborígenes que montavam cavalos "overos". Note-se que don Claudio faz questão de identificar a pelagem dos cavalos, afinal, nada é mais marcante na literatura que coloca como protagonistas gaúchos e "gauchos" do que a figura do homem montado em seu cavalo, o que compõe "o centauro dos pampas"; mas, embora conte histórias de certos exageros, de valentias, em que é sempre o protagonista, seus contos assemelham-se muito com a vida, repleta de cercas, de limites.

Afinal, "quienes hayan oído cuentos de fogón saben que los fogonos no son maníqueos y que en sus cuentos, como en la vida, los personajes buenos pueden estar veteados de ruindades, los personajes malos pueden alojar en su trama hilachas bondadistas, las mujeres más hermosas pueden verse obligadas alguna vez a cagar entre los cardos, los heróes y los semi-héroes pueden comportar-se ocasionalmente 
como gringos asustadizos y hasta morir de muertes en nada heroicas o todo o contrario de heroicas..."

\section{3- "El caballo piadoso"}

O "semi-héroe", Macarrón García, protagonista do "El caballo piadoso", é o exemplo de um "paisano-gaucho", de um nativo, de um "criollo", ou seja, de um homem nascido no Uruguai, descendente do "gaucho", que se afogou de uma maneira insólita, para não dizer tragicômica.

O "cuento de fogón" se inicia pela voz de um narrador onisciente:

"Se cuenta o se contaba que Marcelino García - grande, huesudo, peludoo, sonoro de carcajadas guarangas, conocido en el pago por Mancarrón - era buen bebedor de ginebra, un poco pendenciero, un tanto mentiroso, sospechado de carnear ajeno y, sobre todo, desaforadamente mujeriego. Tenía, a orillas del Río Negro, una media suerte de campo y vivía en ella en la sola compañía de un peón muy viejo y una negra más vieja todavía (vivía en ella es casi un decir: lo más de su tiempo lo pasaba en correrías de busca-hembras)."

Mancarrón é um tipo que se parece muito com o "gaucho" dos primórdios, já que gosta de beber, é um pouco briguento, um tanto mentiroso, desconfiado e, sobretudo, mulherengo. No entanto não corre "eguadas" num tempo livre, já que é um minifundista, vivendo à margem do Rio Negro, em companhia de um velho peão e uma negra. A característica de não ser muito afoito para o trabalho também está nas entrelinhas, afinal passava grande parte de seu tempo em buca de "fêmeas".

Como nos outros "relatos", o narrador onisciente cede lugar ao narrador-autor que insere um trecho, um comentário não ligado com os seguimentos precedentes da narração, o que constitui uma marca de "ruptura con el cánon realista":

"Estoy cansado de que se me diga que hay demasiado sexo en mis cuentos, de que se me acuse, incluso, de sacarle virutas a la pornografia. Es de lo más probable que muchas de esas historias fueran en gran medida apócrifas, ya que gracias a Dios lo fogones ignoran el realismo (por lo menos como perceptiva o propósito) y que la exageración, la elocuencia por la desmesura, es uno de los recursos naturales o 
instintivos de sus narradores. Pero muy de verdad era que no había en leguas a la redonda hembra humana en edad y circunstancias de consumo no galopeada o no tenida en la mira de sua herramienta por el huracanado super-macho."

Marcelino García, o "semi-héroe", decide, apesar de ter chovido muito, encilhar seu cavalo para ir atrás de uma aventura amorosa, mesmo que a negra tenha alertado que o arroio havia transbordado e era perigoso cruzá-lo. Mancarrón responde que "no hay caballo que no nade." A negra acompanhou a saída do "patrón" e "mientras miraba murmuro varias veces, cambiando de idioma, "Tempo aborrecido."

Mario Arregui, ao se referir aos ditos da negra, "nieta ou bisnieta de africanos", tem consciência da artificialização do narrado, pois acrescenta:

"Este narrador no de fogón sino de máquina de escribir, no de chiripá y bota de potro sino de pantalón de pana y zapatillas, supone que lo que mascullaba eran unas palabras muy repitidas en nuestro campo: la versión criolla (aquella frase que habla de palos y bueyes) del refran español: "Más tiran dos tetas que dos carretas"."

A presença do narrador culto supõe, segundo Arregui, menos "artificialidade" ao narrado visto que ele não visa a "esconder sua voz". No entanto este narrador-autor sente-se atraído pela linguagem do ambiente rural, pela memória popular, transmitida por provérbios "criollos", como "más tiran dos tetas que dos carretas", que aviva a narração e, em português, equivaleria aos ditos populares "gosto é regalo da vida" ou a "mais vale um gosto que dinheiro no bolso".

Mancarrón, por "galopar" em busca de "seus gostos", vai encontrar a morte. O arroio ou riacho que deveria atravessar estava demasiado cheio; "pero él, un semi-héroe, no era quién para postergar el encontronazo con una hembra por unos miles de litros de agua apresuarada". Dessa forma, obrigou o cavalo a entrar na correnteza.

Sentia-se, o semi-herói, seguro em cima de seu cavalo. la cantando "los cuatro versos del homicida Martín Fierro: "Limpié el facón en los pastos,/ Desaté mi redomón,/ Monté despacio, y salpi/ Al tranco pa el cañadon"..."

Embora Arregui conheça o valor incontestável do Martín Fierro no tocante à denúnica social, no tocante à identificação do povo uruguaio com a obra, no tocante à 
interiorização da voz narrativa, não deixa de reconhecer, assim como Borges, que o protagonista é um homicida. É uma relação de aproximação e repulsa que Arregui mantém com essa figura, representante do "gaucho" que povoou os pampas até o último terço do século XVIII.

Na metade da travessia, o cavalo começa a se cansar, e Mancarrón percebe que está afundando:

"Un semi-héroe asustado pierde sus dimensiones superlativas y se nivela a los hombres comunes; Mancarrón levantó los ojos al Cielo y al cielo (a la lluvia, que se los hizo bajar) e imploró como un hijo de vecino cualquiera:

- No me deje ahogar, don Dios."

Parece que "Dios" escuta aquele "simples mortal", e o cavalo consegue apoiar-se por algum tempo sobre uma pedra submersa. Mas a correnteza era forte, e o ginete começa a rezar ao seu modo, numa mistura de "padre nuestro" com letras de músicas que sabia: “(...) tu vientre Jesús/ para venir a este baile traje los tres instrumentos(...)"

Para Mancarrón era mais fácil, era natural recitar, rezar os versos de Fierro, "a bíblia gaúcha”, a fazer uma oração.

O desfecho é tragicômico: o cavalo, que havia sido de um cura e era católico, ao escutar a melodia da "oração", sentiu "una gran dilatación mística em su corazón equino y religioso". Nesse momento, o cavalo ajoelhou-se, e a força da água tomou por surpresa o homem que foi desmontado do seu animal e se afogou.

Assim são os "cuentos de fogón" eleitos por Arregui: neles existem "paisanos-gauchos" que, em muitos momentos, são contagiados pela figura do "gaucho-héroe", corajoso, destemido, assim como Mancarrón sentia-se. No entanto são "simples mortais" que têm medo, que são traídos por seus cavalos, mesmo que involuntariamente, e "morrem afogados".

Esses protagonistas dos "cuentos de fogón" também reconhecem os seus limites, assim como don Cláudio, que não conseguia reiterar as histórias de sangue das guerras, "simples" horas de combate. São episódios narrados que denunciam os limites impostos pelas cercas que "alambraram" a vida do "gaucho", cercado por exclusão. 


\section{4- Os contos de Arregui e a tradução de Sergio Faraco}

A primeira coletânea de contos de Arregui traduzida para o português por Sergio Faraco é Cavalos do amanhecer . Nela, há a tradução de 8 contos: "Noite de São João", "Os contrabandistas", "Três homens", "Cavalos do Amanhecer, "Diego Alonso", "Lua de Outubro", "A vassoura da Bruxa" e "Os ladrões". Tal obra foi reeditada em 2003, pela L\&PM de Porto Alegre, com o acréscimo do conto "O regresso de Ranulfo González", e recorrigida, pois a edição da Francisco Alves, segundo Faraco, continha inúmeros erros.

Em 1985, foi publicada A cidade Silenciosa, outra coletânea de contos de Arregui traduzida por Faraco, lançada, no Brasil, logo após a morte do uruguaio em 8 de fevereiro de 1985. A obra é dividida em duas partes. A primeira possui os seguintes contos: "O regresso de Ranulfo Gonzáles", "O gato", "Os olhos da figueira”, "O diabo não dorme" , "Hemisfério de Sombra". A segunda "Vento do Sul", "A casa de pedras", "Formas da Fumaça", "A mulher adormecida", "A companheira", "Um velho homem", "O canto das sereias", "A cidade silenciosa". Na verdade, este livro resgata os contos de Arregui, cuja temática é mais intimista, pautada numa busca de essências, como já abordado por Angel Rama.

Como mencionado, Arregui sugere que o seu primeiro livro de contos em português contenha as seguintes narrativas: "Noche de San Juan" e "Diego Alonso (publicados em Noche de San Juan (1956)), "Tres hombres", "Los contrabandistas" (publicados em Hombres y Caballos (1960)), "El narrador", "La mujer dormida", "Los ladrones", "Un cuento con un pozo" (publicados, em Tres libros de cuentos (1969); "Los ladrones" já havia sido publicado em La sed y el agua (1964); "El narrador", "La mujer dormida" e "Un cuento con un pozo" serão republicados em El narrador (1972)); "El regresso de Odisea González" (publicado em El narrador (1972) e republicado em La escoba de la bruja (1979)), "Un cuento con insectos", "Un cuento de coraje" e "La escoba 
de la bruja" (publicados em La escoba de la bruja (1979)). A ordem a que sugere Arregui é a cronológica.

Porém, Faraco descarta certos contos e sugere uma ordenação própria em Cavalos do Amanhecer. Isso se justifica porque o autor brasileiro busca os contos de Arregui "relacionados al campo" e que "crean un cierto perfil del gaucho", como já mencionado. Pretende traduzir os contos que "recuperan al gaucho como tipo humano, con sus peculiaridades y, exagerando, con su "nacionalidad".

Descarta, então, "El narrador", que se aproxima mais a um ensaio do que a um conto, como já analisado; "La mujer dormida" e "Un cuento de coraje", cuja temática foge àquela pretendida por Faraco.

Em Cavalos do amanhecer, Faraco elege praticamente todos os contos, que proporcionam a visão de Arregui do que restou do "comarca das coxilhas". Essas narrativas serão o objeto de nosso estudo.

No prólogo da edição de 1982, Faraco escreve:

"Se algum dia alguém recolhesse o fio imaginário que separa o Brasil do Uruguai, na manhã seguinte todos os gaúchos, rio-grandenses e uruguaios despertariam como Martiniano Rios no conto título, aos nascer do sol, para aquentar a água e cevar o mate, num rito quase impessoal sacralizado por gerações de mateadores, e falariam do tempo, eguadas, de parição de vacas, como dom Marcial do inolvidável Lua de Outubro. E por mais que se regozijassem os distantes governos de Brasília e Montevidéu, na campanha uruguaia e rio-grandense a novidade seria sempre um pleonasmo.

(...)

Mario Arregui, como Jorge Amado, Vargas Llosa, García Márquez e outros escritores americanos que iluminam a cena regional, lega à literatura universal o substrato do gaúcho como tipo humano. Mas não se trata de um criollista, na acepção maledicente que tem-se dado ao termo. Arregui é um resultado da melhor mistura da ordem regional com o hausto cultural da modernidade, aberto esse caminho literário pela sua sensibilidade ao político e pelo seu talento de grande escritor.

No mudo desespero de Martiniano Rios, na luta íntima do impetuoso Reyes, nas visões e superstições dos irmãos Correa, no desejo de Pedro Arzábal, na honradez do sargento Maciel, na coragem de Diego Alonso e na atmosfera do assalto à padaria de Giovanni Orsi, estão presentes, íntegros e lapidares, os traços essenciais do homem do sul e um rasgo de nossa identidade americana - a contribuição que daremos mais tarde para um mundo sem fronteiras." 
Retomar o contexto em que esses contos foram escritos; desvendar esse "gaucho" que surge nos contos de Arregui para confrontá-lo com o "gaúcho" de Faraco são os objetivos.

Para a análise, seguiremos a ordem estabelecida por Faraco em Cavalos do Amanhecer, e consideraremos não só o texto original em espanhol, mas também a sua tradução, que servirá de auxiliar na interpretação desses contos.

\section{5- Os contos de Arregui e o "gaucho"}

\section{1- "Noche de San Juan"}

"Noite de São João" abre o livro Cavalos do Amanhecer. Este conto também abre Noche de San Juan (1956), primeiro livro de contos de Arregui, que possui mais cincos narrativas : "Mis amigos muertos", "El gato", "El viento del Sur", "Las formas del humo" e "Diego Alonso". Dessas, apenas a inicial e a final colocam em questão a coragem, a honra do "gaucho".

Essa ordenação do primeiro livro de Arregui é interessante, pois, apesar de ele se identificar com os escritores da geração de 45 do Uruguai, que buscavam, de maneira geral, uma visão de mundo ligada à capital Montevidéu, em plena expansão industrial, tanto no seu conto inicial, como no final, ele retoma a figura do "gaucho" e conserva certas técnicas consideradas parte da tradição, como "o narrador exterior à história e não representado (sem nome, sem rosto, pura ficção narrativa) que comunica um conhecimento irrestrito formulado em terceira pessoa". No entanto a figura do "gaucho" é desmistificada e não possui uma psicologia rasa, pois seu persongem vai sofrer de solidão, de tristeza.

Esse narrador que vai mergulhar na psicologia de Francisco Reyles, personagem principal de "Noche de San Juan", é onisciente; mas seu saber tem a ver com uma psicologia culta, de quem observa o descendente do "gaucho" e supõe o seu sentir, ou seja, a voz da personagem é intermediada pela voz do narrador culto. Apenas quando há discurso direto, tomaremos contato com uma linguagem mais regional.

Nesse momento, é interessante observar que a primeira edição de Cavalos do Amanhecer, editada pela Francisco Alves, em 1982, não preservou, quando há o discurso direto, a linguagem regional do Uruguai que, como no Rio Grande do Sul, utiliza a segunda pessoa (tu) ao invés da terceira (você). 
Quando Reyles, por exemplo, conversa com a prostituta, chamada Ofélia, no conto em espanhol, o diálogo é o seguinte:

“- Dame fuego.

- No; te doy un fósforo: así te veo la cara."

A tradução desse fragmento, na primeira edição de Cavalos do Amanhecer, é a seguinte:

“- Me dá fogo.

- Não, Ihe dou o fósforo e assim lhe vejo o rosto."

Observe como a editora do Rio de Janeiro "adapta" o diálogo às tendências do centro que preferem o uso da terceira pessoa à segunda. Já na edição de 2003 da LP\&M, essa imprecisão é revista, e a tradução mantém o linguajar do homem do Cone Sul:

“- Me dá fogo.

- Não, te dou o fósforo, assim vejo teu rosto."

No livro Correspondencia, Faraco na carta para Arregui, datada em 21 de outubro de 1982, observa esse "erro" da editora carioca:

"Recibí un ejemplar de Cavalos do amanhecer. Leí todo el libro y noté algunos problemas de correción (no me enviaron las pruebas, tal como habían quedado). Otro problema és que los correctores, sin consultarme, decidieron cambiar el tratamiento de los diálogos de "tu" para "você". El carioca no dice "tu", entonces aplicaron ese "você" o el verbo conjugado en la persona correspondiente, que es la tercera. Algunas veces cambiaron el tratamiento y olvidaron cambiar el verbo, dejándolo en la segunda Pessoa. Paciencia. Tu libro está muy bien y ha de superar esta traición de Francisco Alves."

Em virtude dessas questões editorias, sempre nos remeteremos, quando necessário, à edição de 2003.

Como observado anteriormente, a linguagem regional, mais próxima ao homem do campo uruguaio, ao "gaucho", só aparecerá nos diálogos. O que prevalece é o discurso 
do narrador culto. A descrição da paisagem campeira, por exemplo, é tomada por um tom intimista, repleto de comparações subjetivas que notadamente refletem essa voz:

"Después de muchos dias consumidos em incesante arreo de tropas por campos y caminos donde el otoño sembraba sus mil muertes, Francisco Reyes volvía al pueblo en un atardecer desnudado y alto como la victoriosa espada de un ángel, mientras cien hogueras dispersas anunciaban el nacimiento de la noche de San Juan."

Por outro lado, apesar de não ceder a voz a Reyles e nem usar como técnica o discurso indireto livre, o narrador onisciente, em muitos momentos, demonstra a ligação do personagem com o "pago", sua terra, característica que desde sempre povoou a literatura que fala do "gaucho":

"Su pecho también se abria, se abría dulcemente y se dilataba ante viejas ternuras y recuerdos aún tibios que lo alcanzaban desde el sitio donde se repliega la infancia. Y su corazón iba liviano y ágil como un niño."

Reyles, depois de rever os amigos, decide ir às ruas dos prostíbulos. Mas quando sai de uma dessas casas, por volta da meia-noite, sente que sua solidão, ao invés de desaparecer, apenas aumenta:

"Además del aflojamento y la pesadumbre que suelen suceder a las intensidades de la carne crucificada em el sexo, crecía en él una insatisfacción precisa y punzante, decididamente hostil, como si impulsos no animales que lo habitaran (que vivieran ocultos en su carne, parasitamente) estuvieran alzándose - rebeldes, enconados y ciegos sobre el desmayo del deseo animal agotado. En su alma nacían ansiedades sin destino y despertaban apetencias ya condenadas a frustrarse, y se rompíam equilibrios, se iniciaban resquebrajamientos... Sintió que necesitaba el alcohol para defenderse, para emerger de la angustia que ya comenzaba a ceñirle la garganta... Caminó unos metros y entró en un bar y pidió caña."

Essa descrição do sentir de Reyles demonstra bem a intenção de Arregui: proporcionar densidade psicológica àquele homem movido por "impulsos animales", "bárbaros".

Como já abordado, apesar de reconhecer o valor de Martín Fierro, Arregui não deixa de classificar Fierro como bárbaro, aspecto que almeja afastar de Reyles, que já 
não é mais o "gaucho" dos campos livres, sem cerca, mas aquele que sofre com a transformação do Pampa, com sua vida de tropeadas, sem muito sentido, porque é um ser em busca de algo que não se resume mais à doma, ao sexo, ao alcóol. Mas se encontra em busca do quê?

"Sem rumo", encontra com uma prostituta e a acompanha para dentro do quarto dessa mulher. Ao se deitar com ela, ao acariciar seu rosto sente que "el tumulto de sua alma se hacía más simple, más coherente". Sexo não mais o satisfaz, pois deseja, embora pouco provável com uma prostituta, o encontro verdadeiro, o que se resume, no conto, a um longo abraço:

"Y Francisco Reyes levanto la cara del pelo que olía a sueño y a noche y rodeó el talle de la prostitua con el brazo izquierdo y la hizo girar um poco hacia su lado. Cerró con fuera los ojos y se apretó contra el vasto, opuesto mundo vivo y tembloroso. La mujer intentó hablar, pero él le tapó la boca con el hombro, y ella -comprendiendo - giró hasta ponerse por completo de costado y lo abrazó estrechamente, en silencio. Largos minutos permanecieron así, como dos náufragos arrojados por el azar en la concavidad de una misma ola."

Depois disso, levanta-se e vai embora. Ao passar perto da fogueira, a que, no início da noite, havia lançado folhas secas para fazer o fogo crescer (metáfora da luz que clareia seu interior?), pisa nas cinzas que sobraram. Ao aparecerem brasas, esmaga-as "rencorasamente", porque reconhece que na sua vida não sobra lugar para o incandescente.

Esse conto, escrito em 1956, revela o contexto pelo qual passa o Uruguai. De 1945 a 1955, no período pós-guerra, o Uruguai vive o chamado "decenio glorioso". O avanço da industrialização foi o marco fundamental do processo reformista do neobatllista:

“El Ilamado "decenio glorioso" (1945-1955) mostro a la economía uruguaya creciendo a una tasa anual de $8 \%$ mientras el promedio mundial era del $5 \%(\ldots)$. En forma paralela, se mantenía incambiado el estancamiento del sector ganadero uruguayo.(...) El processo industrializador, aún en su momento de auge, también denotaba sus "grietas". La prosperidad uruguaya volvía a ser inadvertidamente frágil."

Quem governou o país de 1947 a 1951 foi Luis Batlle Berres, sobrinho de Battle e Ordóñez. Embora seja demarcada a diferença notória de contextos históricos entre 
esses dois governos (nos anos cinqüenta houve a mudança de hegemonias no mundo capitalista e a inserção internacional do Uruguai já não era a mesma do começo do século), é possível fazer uma comparação entre o "batllismo" originário e "sua nova versão". As semelhanças no discurso eram muitas: "la afirmación liberal com uma proyección social y en algún caso moderadamente socializante; la promoción de um Estado reformista, que no sustituyera la iniciatica privada pero que permitiera "dirigir" la articulación armónca de los intereses del capital y del trabajo; la invocación del rol anticipatorio de las políticas públicas, con el fin de garantizar las estrategias de concertación social y prevenir la eventualidad de cualquier "desorden revolucionario"; la promoción de la industrialización como clave del desarrollo económico y la redistribución más justa de los ingresos; la ratificación del alineamiento panamericanista; entre otras."

Porém a distância entre a teoria e a prática era visível: "a tono con su tiempo, la centralidad de los principios democrático- liberales en su programa político resultó mucho más vigorosa; en forma paralela, su programa de reformas sociales fue bastante menos audaz y denotó un mayor conformismo en el plano ideológioco."

Importante é ressaltar que a geração dos escritores de 45 do Uruguai, ou "geração crítica" não endossou esse "orgulho ingênuo" dos uruguaios em relação ao seu desenvolvimento, porque tinha consciência da crise nacional subjacente; tinha consciência do "agotamiento irremediable de país batllista y su modelo del convivência."

A partir de 1955, surgiu uma grave crise estrutural no Uruguai, em virtude da mudança radical dos mercados capitalistas:

"En el área latinoamericana, al tiempo que se expandían fuertemente las inversiones directas de los Estados Unidos en la región, decrecía la demanda internacional respecto de los productos latinoamericanos. Los precios internacionales iniciaban de ese modo un curso claramente desfavorable para los países del continente, que en forma progresiva ingresaban en la espiral del endeudamiento."

Continuou, em meados dos anos cinqüenta, a crise no setor pecuarista que se somou ao freio da expansão agrícola. Além disso, o freio ao impulso industrializador ocorreu por causa de problemas já visíveis durante seu desenvolvimento acelerado: "la índole muchas veces particularista e indiscriminada del proteccionismo oficial, que comprometió la viabilidad del projeto; la apuesta restrictiva a um mercado interno pequeno, sumada a la dependência de un mercado inelástico de bienes de capitales; la 
escasa atención prestada a la innovación tecnológica y a su necesaria vinculación con uma reforma educativa profunda (...). El estancamiento productivo y la caída de las exportaciones se volvían más graves ante una nueva constatación de la rigidez de la estructura de importaciones. Por último, la situación también deteriorada de las economías vecinas clausuraba la venta de servicios (turismo, intermediación financiera y comercial, etc.) como vía de salida - ya clásica - de la economía uruguaya."

Em 1956, o Uruguai vive um contexto de intensa crise frente às modificações externas e às mudanças do eixo de poder. Embora continuassem a concentrar terras, os criadores de gado, desde o início do século, viam-se com as mãos amarradas no tocante ao desenvolvimento da pecuária. Se a crise afeta aos poderosos, o que dizer então daquela população que não tinha terra, não havia imigrado para Montevidéu em busca de emprego, mas morava em pequenos povoados? Esse é o caso de Reyles, cuja angústia e desamparo, além de serem sentimentos sempre presentes no homem, o que oferece ao conto universalidade, pode também ser reflexo de uma sensação de exclusão que o personagem não sabe ao certo identificar de onde provém.

De que período provém a "ninguendade" desse homem solitário de "Noche de San Juan", "sem eira nem beira" é respondido no próximo conto intitulado em Cavalos do Amanhecer de "O regresso de Ranulfo González", publicado no livro El Narrador (1972) de Arregui.

\section{2- "El regresso de Odiseo González"}

Interessante notar que, como "Noche de San Juan", "El Regresso de Odiseo González" é um conto escrito num momento de ampla crise no Uruguai, que culminou no golpe de Estado de 27 de junho de 1973.

A crise que se iniciou a partir de 1955 segue até o golpe. Em 1958, o partido Nacional, representado pelos blancos, apoiados pelos criadores de gado, tirou do governo os colorados, que permaneciam no poder há quase um século. Iniciou-se, então, o primeiro projeto liberalizador. No entanto, a intenção de reforma monetária de 1959 e os projetos de liberalização firmados com o FMI em 1960 não encontraram condições políticas para sua aplicação, já que havia a resistência dos trabalhadores urbanos, organizados num forte movimento sindical, contra as frações capitalistas 
vinculadas à indústria. O Estado manteve por um tempo seu papel conciliador, mas em 1967, os colorados voltam ao poder.

Em 1968, quem sobe ao governo é o autoritário Pacheco Areco, que "no vacilo en integrar directamente a su gobierno a algunos de los más conspicuos representantes de los sectores empresariales", o que marca a entrada definitiva do capital internacional no Uruguai.

Mas a economia capitalista mundial, no começo dos anos 70 , ingressou numa fase crítica caracterizada pela decadência dos negócios, pela quebra da precária ordem financeira internacional de Bretton Woods, pela crise energética (a partir da triplicacção do preço do petróleo em 1973) o que alteraria radicalmente os limites da produção industrial e os fluxos financeiros. Dessa forma, diversos países da América Latina foram submetidos às ordens dos generais-ditadores, que praticaram a violação aos direitos humanos e civis, a fim de manter uma sociedade voltada aos estímulos externos.

Frente a esse contexto de veto aos direitos do cidadão uruguaio, entreguismo à política capitalista que tem como centro os EUA, Arregui rememora em "El regresso de Odiseo González" que a arbitrariedade sempre foi uma constante no Uruguai desde seus primórdios.

"El regresso de Odiseo González" conta a saga de Ranulfo que, após se fingir de morto para ter a vida poupada na guerra de fronteira de 1820, chega muito machucado à estância de um vasco que lhe dá abrigo. Lá permanece e resolve regressar ao seu lar mais dois anos depois da manhã que havia saído para a guerra e fora machucado. Quando regressa, sua mulher tem outro. No entanto, ela opta por ele, pai de seus filhos, e "todo volvió a ser como antes de la guerra."

Esse conto foi publicado em 1972, e, com o olhar voltado para o Uruguai dessa época, Arregui procura retomar certos rasgos que evidenciam 0 quanto 0 "paisano-gaucho", desde as guerras civis do início do século XIX, é submetido a uma lógica questionável.

Em "El regresso de Odisseo González", embora o narrador onisciente prevaleça, em alguns momentos, uma voz sutil sobrepõe-se à narração em $3^{a}$ pessoa e se deixa ouvir. Essa voz manifesta-se na $1^{\text {a }}$ pessoa do plural e, apesar de conhecer muito bem a realidade narrada, não cede a voz a um "paisano-gaucho", ao contrário do que acontecerá na maioria dos contos de Faraco, como será analisado adiante. Quem está 
por trás dessa voz é Arregui que, em muitos momentos, por meio de observações entre parênteses, demonstra sua erudição e seu contato com uma literatura universal. Assim, 0 escritor uruguaio busca evidenciar que embora o enredo de "El regresso de Odisseo González" se passe no Pampa uruguaio, na região de fronteira, durante a guerra de 1820, é uma situação que não é local, apesar de trazer as peculiaridades daquela região, porque a história desse Ulisses campeiro é uma espécie de Odisséia.

Já o título remete a essa constação. Interessante notar que Faraco, ao traduzir esse conto, atribui-Ihe o título de "O regresso de Ranulfo González" e suprime a maioria das observações feitas entre parênteses, alheias, de certa forma, à continuidade da narração. Observem-se as seguintes passagens:

"De ahí en adelante, con la ayuda de una china de pocas carnes (charcona diría un nativista; belle magre, un francés) y movimientos hombrunos y del yuyo denominado carnicera, lo fue curando de a poco"

"Hay sin duda algo que misteriosamente relaciona la sangre y el alma de un hombre con lo que se llama el pago ( palabra que alude no sólo al paisaje sino también al calor humano y que C. A. Leumann, con error, supone en desuso); de algún modo sentía esa relación, como una bienquerencia indefinida y vasta."

Faraco elimina essas explicações da tradução:

"E foi curando-o pouco a pouco, com a ajuda de uma china de poucas e firmes carnes e movimentos de mancho, e com emplastros de uma erva chama carniceira."

"Sem dúvida, existe algo que, misteriosamente, associa o sangue e alma de um gaúcho ao que se chama pago, e Ranulfo sentia essa associação como uma benquerença indefinida e vasta."

O único momento em que Faraco conserva "essas explicações", provindas diretamente da voz do narrador-autor, é na seguinte passagem:

"Quando a aurora de rosados dedos, filha da manhã, anunciou o dia (assim traduz Homero Dom Federico Baráibar), Ranulfo González, que dormira bem, estava tomando mate à beira do sangão (...)" 
A passagem no texto original é a seguinte:

"Cuando la aurora de rosados dedos, hija de la mañana, anunció el día (así traduce a Homero don Frederico Baráibar), nuestro González - que había dormido bien - estava tomando mate en el cañadón convencionalmente bucólico (...)"

Essa explicação entre parênteses, diferentemente das outras, está diretamente ligada ao enredo, pois o leitor culto perceberá a intertextualidade, o "cruzamento num texto de enunciados tomados de outros textos". A história do Ulisses campeiro de Arregui, ou seja, de Ranulfo, lembra a trajetória do herói de A Odisséia de Homero (poema provavelmente do século VIII a.C.) que narra as viagens e as aventuras de Ulisses em duas etapas: a primeira compreende os acontecimentos que, em nove episódios sucessivos, afastam o herói de casa, forçado pelas dificuldades criadas pelo deus Posêidon; a segunda consta de mais nove episódios, que descrevem sua volta ao lar sob a proteção da deusa Atena. Como afirmado, Faraco preserva-a.

Indubitavelmente, o que Arregui visa com essa técnica é não só mostrar que a situação é universal, apesar de certas particulariedades regionais, mas também romper com o "canón realista", por meio do trabalho intertextual que consiste na integração de segmentos de discurso de outros textos na continuidade da narração. Esse esforço torna o texto dotado de uma artificialidade, de um estranhamento que só são entendidos plenamente por quem se aprofunda na literatura de Arregui. Portanto, Faraco, embora não descaracterize o texto original do autor, apropria-se dele e elimina a maioria desses parênteses. Eliminar esse excesso de erudição é aceitável para um autor como Faraco que, ao tratar da figura do "gaucho" de ontem, ou de hoje, como será analisado, tenta um olhar mais de dentro do universo narrado.

Mas esses "parênteses" nem sempre são uma espécie de pausa para falar do erudito. Muitos são colocados para evidenciar os provérbios "gauchos", ou os dizeres de Ranulfo, relacionados à china com quem era amasiado no tempo que ficou na estância do vasco:

"No es que se hubiera aquerenciado desmedidamente em aquella estancia vasco-cimarrona o que lo amarraran a mágicas estacas los 
vellos del publis de la china hombruna ( dicen los que saben que uno solo de los vellos secretos de uma mujer puede atar más que siete coyundas)."

"A los cinco meses, más o menos, Arnulfo caminaba sin demasiadas dificultades, pese a la bala no extraída; a los sietes meses, siempre más o menos, podía montar en el petizo piquetero - para vueltas cortonas- y hacía casi cuatro que dormía con la china de cuerpo estricto que tranqueaba como un hombre y trajaba como dos y equivalía en la cama a por lo menos tres mujeres. (Es mismamente una yegua com colmillos, se decía Arnulfo con sonrisa admirativa). Mientras tanto, uno de esos pactos de caballeros que nunca se cumplen había puesto a la guerra uun punto final que valía sólo lo que un punto y aparte."

A tradução de Faraco é:

"Não que estivesse por demais aquerenciado àquele paraíso vasconço ou que o amarrassem a mágicas estacas os pentelhos da china amachorrada (dizem os entendidos que um só pentelho de mulher pode segurar sete juntas de bois)."

"Ao cabo de mais ou menos cinco meses, e apesar da bala encrava, Ranulfo caminhava sem dificuldade. Com mais ou menos sete meses podia montar o petiço piqueteiro em volteios curtos e já fazia quatro que dormia com a china de corpo justo, qua andava como um homem, trabalha por dois e, na cama, valisa por três mulheres ("É igual a égua de colmilho", admirava-se Ranulfo). Entrementes, um daqueles acordos de cavalheiros que nunca são cumpridos tinha dado à guerra um ponto final, que não valia mais do que um ponto e vírgula."

Note-se, por exemplo, que essa observação entre parênteses coloca toda a expressividade e sabedoria do mundo "gaucho' na fala de Ranulfo que compara a mulher com quem dormia, durante sua permanência na estância do vasco, com uma égua de colmilho. Colmilho é o dente canino. Os cavalos os possuem, mas as éguas não. Excepcionalmente, aparecem éguas com colmilhos, isto é, com características e temperamento masculinos, e diz-se que, em regra, são mais esforçadas e valentes do que os machos.

Ademais, o narrador onisciente culto, em suas descrições, infiltra-se nesse território da fronteira. Conta que Ranulfo "vivia com el sosegado deslumbramiento de lo 
que era, un convaleciente, y dias de um tiempo loiso y sin numerar - ese tiempo de estancia em que se vê crecer los paraísos del guardapatio y que prestidigita un ternero mamón en un novillo adulto - giraban sobre él."

Ao narrar a chegada de Ulisses, ou melhor, Ranulfo ao seu "pago" utiliza-se de personificações, comparações, metáforas para descrever a sanga e avivar o ambiente campeiro, o que constitui uma pequena "mancha" descritiva. A descrição estabelecida por meio de quadros ou unidades fechadas e completas (como retratos) retoma a técnica da tradição realista, incorporada, por exemplo, por Javier Vianna.

Observe-se o trecho:

"A unas poças cuadras de aquel rancherío se dilataba um cañadón que no carecía de gramilla muelle y de árboles rumorosas, ricos em pájaros cantores, y en cuyas aguas límpidas vivian - siempre como em uma fiesta asombrosamente silenciosa - miles de mojarras locas, o que se hacían las locas, con las que se entreveraban de cuando em cuando otros pequeños peces más derios o más tristes, que parecían coloreados por um decorador de paciência de proso y prodigiosa inventiva."

Outra observação relevante é a questão de Arregui não se perder entre as datas e ambientes ao retratar a situação da vida de Ranulfo, marcada pela Guerra de 1820 . O conto se inicia com a seguinte constatação:

"En una de las batallas o entreveros de nuestras guerras civiles, um hombre llamado Arnulfo Gonzálvez cayó malherido de bala. El bando al que Ranulfo pertencia era el ocasionalmente derrotado, y nuestro homem, temiendo la degollatina, permaneció haciéndose el muerto bajo el sol y las moscas de la tarde joven y al lado de dos muertos de verdad."

No início, parece que ao narrador não interessa muito destacar os fatos históricos, mas sim detalhar o corte que a guerra proporciona à vida de Ranulfo, que não é o herói corajoso, nem o covarde. Prevalece seu instinto humano de sobrevivência que o faz temer a morte. Assim ele se finge de morto para não ser degolado.

Como já observado, apesar de muito machucado, Ranulfo consegue chegar à estância de um vasco que Ihe dá abrigo. O vasco, que se declarava neutro diante desses entreveros, conclui: 
"Yo em rimas y pujas de orientales no me meto", pero simpatizaba secretamente - mucho - con la divisa a cuyo servicio Ranulfo había despiado su caballo en semanas de andanzas y combatido una mañana."

Diante da observação do narrador onisciente de que o vasco simpatizava com a facção a qual pertencia Ranulfo, fica evidente que o sentimento de neutralidade dá margem ao posicionamento. Saberemos, mais a frente, que Ranulfo tinha quase morrido na batalha de Tacuarembó, lugar, segundo a historiografia, da derrota das forças de Artigas na Província Oriental pelos portugueses em 22 de janeiro de 1820.

Embora o narrador não adense os dados historiográficos sobre a batalha, ele não se perde nas datas, pois afirma que Ranulfo, após aproximadamente sete meses de sua chegada à estância do vasco, soube que "mientras tanto, uno de esos pactos de caballeros que nunca se cumplem había puesto a la guerra um punto final que valia solo lo que un punto y aparte." Observe que se ele se feriu no final de janeiro de 1820, é em setembro desse ano, aproximadamente sete meses depois, que Artigas declara o final da guerra.

Interessante é refletir sobre esse entrevero na fronteira que marcou a História tanto do Uruguai como do Brasil, para elucidar porque o vasco se idenficava com a facção pela qual Ranulfo quase morreu. Além disso, é interessante a questão de Arregui escrever um conto ambientado no momento em que Artigas, "el protetor de los Pueblos Libres", perdia a batalha para os portugueses e, por meio da figura do vasco, mostrar a identificação com Artigas. Tal identificação também era a de historiadores contemporâneos a Arregui.

O professor doutor e historiador Washington Reyes Abadie, nascido em Montevidéu em 1919, ou seja, comtemporâneo de Arregui, propaga a seguinte visão de Artigas:

"Erigido em Protector de los Pueblos Libres - vigorosa y dinámica expresión de una federación republicana fundada en el concierto de las "soberanias particulares" de las Provincias, con directa participación y gobierno de los pueblos y en creciente desarrollo de sus economías dentro de un naciente "mercado común", protegido por un eficaz régimen de aranceles aduaneros y dotado del excelente puerto ultramarino de Montevideo - , el genial Caudillo consituía un serio obstáculo al programa de hegemonía unitaria y de puerto y aduana únicos del ex Virreinato, promulgado por la oligarquía patricia de Buenos Aires. 
Por lo demás, la tosuda defensa y promoción de los "más infelices" negros e zambos libres, indios y criollos pobres - lo presentaban como un jpeligorso "anarquista" ante las "clases principales" de Montevideo y Buenos Aires."

José Gervasio Artigas, nascido em Montevidéu no dia 19 de junho de 1764, é considerado por muitos historiadores o herói nacional uruguaio pela sua atuação na então Banda Oriental na década de 1810, liderando o movimento pela emancipação da mesma e rechaçando a presença espanhola, o centralismo buenairense, e as ocupações luso-brasileiras do atual Uruguai.

Artigas governa toda a Província Oriental a partir de 1815, conhecida como a Pátria Velha, criando, junto com Santa Fé, Entre Rios, Corrientes e Córdoba, a Liga Federal, com o intento de oporem-se à centralista e unitarista Buenos Aires.

Sobre a união destas províncias, Lynch observa que “El 'protectorado' en realidad no fue nunca más que una incómoda asamblea de caudillos locales, cada uno de los cuales miraba de reojo a su vecino, al igual que a Buenos Aires".

Apesar de aparentemente Artigas estar à frente da Liga, na prática, o seu poder está delimitado ao território oriental, arrasado e destruído pelos anos de guerra, o que dificulta o seu governo. Porém, uma vez no poder, toma diversas medidas para recuperar a Província Oriental, através do restabelecimento do comércio e dos campos, ambos assolados pelos conflitos no interior do seu território, conforme Lynch assinala, quando cita que a produção de alimentos dos orientais não era suficiente para abastecê-los, tendo que importar cereais; entretanto, devido ao comércio, debilitado, uma quantidade ínfima adentrava o país.

Diante desta situação caótica, Artigas toma medidas para revitalizar o comércio, realizando acordos com os britânicos, em que os portos de Montevidéu e Colônia passam a ser abertos para eles. O de Maldonado também não é esquecido pelo "protetor dos povos livres", que age no sentido de recuperá-lo, entretanto sem negociá-lo com os ingleses.

No campo, o caudilho promove a reforma agrária, expropriando as terras dos seus oponentes e passando-as para os grupos mais desfavorecidos da sociedade oriental que o apoiaram. Porém, Artigas estabelece certas condições, conforme explicita Padoin: 
“(...) Artigas fez a expropriação das terras e do gado daqueles que se opuseram às suas forças. As terras foram distribuídas, em forma de pequenas propriedades, àqueles que o apoiaram e, entre eles, os que se encontravam na condição de despossuídos e desclassificados da sociedade de então, como indígenas, gaúchos, escravos libertos, etc. (...) Os que as recebiam deviam cultivar as terras e/ou recuperar o rebanho, sob o risco de reverter a terra para o controle do Estado que se formava $(\ldots)$.

A autora afirma que com tais atitudes, Artigas retaliaria os seus " inimigos e pretendia garantir o desenvolvimento econômico da região, além de garantir o efetivo (soldados) para as lutas armadas."

Lynch afirma que a falta de contingentes leva Artigas a aceitar em suas tropas escravos negros, tanto de sua província, quanto do sul do Brasil, e, assim, os cativos ganham uma espécie de emancipação, o que não agrada aos proprietários de terras.

Outra questão que não agrada aos estancieiros é o programa de Artigas, de cunho reformista, voltado para as classes mais pobres da sociedade oriental, que receberam terras e gado do governo estabelecido em Montevidéu.

Ainda sobre a política agrária de Artigas à época em que está no poder, Bushnell afirma que o caudilho "(...) introduziu uma das medidas mais interessantes e originais do período da independência" e que "(...) Artigas foi aclamado o primeiro grande 'reformador agrário' da América do Sul (...)", entretanto, sem ignorar que o caudilho necessita que estas terras estejam a produzir, e que Artigas crê que a melhor maneira para que isto ocorra é entregando-as a pequenos proprietários.

As medidas tomadas na margem esquerda do Prata desagradam ao poder estabelecido no lado direito: Buenos Aires vê, pela ação de Artigas, o seu projeto de exercer o controle sobre as demais províncias ameaçado, o que prejudica os seus interesses econômicos e políticos.

Artigas não causa desagrados somente no Rio da Prata. Na Guanabara, a corte aí instalada desde 1808, também não vê com bons olhos o governo do caudilho oriental. A insatisfação causada por Artigas em ambos os governos é assinalada por Padoin: 
“(...) o domínio da Banda Oriental e a constituição da Liga Federal com suas ações e determinações a partir de concepções federalistas e republicanas, como forma de Estado, provocou reações tanto por parte dos portenhos quanto dos luso-brasileiros".

Assim, já em 1815, começam os preparativos militares, sob o comando do general Carlos Frederico Lecor, por parte do governo português sediado no Rio de Janeiro, para atacar a Banda Oriental.

No ano seguinte, as tropas lideradas por Lecor adentram o território oriental, tendo como justificativa as constantes perturbações à fronteira com o Rio Grande por parte dos artiguistas e o desrespeito para com a mesma, além de que o projeto do Protetorado de Artigas incluía esta região brasileira. A estas justificativas, soma-se o velho anelo lusitano de estender seus domínios ao Rio da Prata. Lynch ainda observa que os ocupantes adentraram o território prometendo levar paz e prosperidade aos orientais.

A opor-se a Portugal, segundo Padoin, Buenos Aires coloca-se contrária ao ataque luso-brasileiro, porém não possui forças para deter as tropas joaninas, limitando a sua atuação à tentativa de Pueyrredón de demover Portugal da idéia, no que malogra; Frutuoso Rivera também tenta impedir as tropas de Lecor através da força, mas é igualmente derrotado no seu intento de impedir a presença luso-brasileira no território de Artigas.

Já Lynch afirma que os portenhos viam positivamente a queda de Artigas e de suas propostas federalistas, mesmo que para derrotar o caudilho e o seu projeto, Portugal viesse a entrar em cena, tendo Pueyrredón sido conivente com os invasores pela queda do inimigo comum.

Lima ainda observa que Buenos Aires poderia prestar socorro a Montevidéu, entretanto não o faz em virtude de Artigas opor-se à subjugação aos portenhos:

"O auxílio seria concedido do melhor grado se Montevidéu anuísse em incorporar-se ao organismo político das Províncias Unidas; mas perante suas veleidades persistentes de separação, Buenos Aires preferia esquivar-se (...) mandando todas suas forças disponíveis para os lados do Chile e decidindo a invasão capitaneada por San Martín". 
Em relação a Artigas frente ao poder da sua região, Carneiro observa que "soubesse Artigas manejar os bastidores da política sul-americana, fosse mais diplomata e menos sonhador como soldado, estaria garantida a emancipação do Uruguai desde 1815". Entretanto, não foi isto o que ocorreu.

O general Lecor chega a Montevidéu no dia 20 de janeiro de 1817, ocupando-a. Entretanto, as tropas de Artigas não se dão por vencidas e cercam a cidade, porém é inútil. Artigas jamais terá Montevidéu de volta, o que não impede que os artiguistas continuem a resistir à presença estrangeira no interior do território oriental, nem que ocorram ataques às Missões e à fronteira do Rio Grande.

Sobre a impopularidade de Artigas, Padoin observa que “(...) o pensamento antiartiguista começou a crescer, inclusive por parte de alguns caudilhos das províncias litorâneas, desgastados com o prejuízo das guerras e sedentos por obterem o apoio de Buenos Aires como forma de assegurarem os seus interesses. A guerra afetara tanto a riqueza monetária das cidades, dificultando o comércio, quanto a zona rural com a escassez do gado vacum e cavalar".

Lynch ainda mostra que os setores mais altos da sociedade oriental apóiam os portugueses e, ao abordar o posicionamento dos estancieiros, o autor assinala que a razão deste suporte dá-se porque esses proprietários estão “(...) posiblemente alarmados por el primitivo populismo de Artigas, tranquilizados por los valores sociales señoriales del Brasil, y satisfechos por la vuelta de la ley y el orden al campo". Portanto apóiam o general Lecor.

Lima também observa que Lecor sabe tirar proveito da situação, pois à medida que o poderio de Artigas encolhe no território oriental e o seu cresce, a população mostra-se mais favorável aos ocupantes, e, assim, o general português militariza a população e a organiza contra o caudilho.

Artigas abre duas frentes de batalha. Além da frente contra os luso-brasileiros, citada anteriormente, o caudilho envolve-se em conflitos com Buenos Aires, pois os centralistas desta cidade tentam acabar com os caudilhos da Liga Federal, entretanto, os portenhos saem derrotados do embate. 
Paralelamente, as tropas artiguistas começam a sofrer várias baixas em 1819. Em 1820, a situação de Artigas complica-se: em 22 de janeiro, as forças luso-brasileiras impõem-Ihe a derrota de Tacuarembó, que leva o caudilho a refugiar-se na província de Entre Rios, que, aliada à Santa Fé, derrota Buenos Aires em 1 de fevereiro.

Apesar de os federalistas terem vencido a peleja, isto não significa que foi algo positivo para Artigas, ao contrário, o caudilho oriental perde o controle sobre os litorâneos, que, por sua vez, não possuem interesse em manter uma guerra junto com Artigas contra o Reino Unido de Portugal, Brasil e Algarve.

Mas Ramirez, caudilho de Entre Ríos também se volta contra Artigas. Trava-se o embate decisivo entre os dois caudilhos em 24 de junho de 1820 em Las Tunas, quando o de Entre Rios derrota definitivamente José Gervasio Artigas, que declara o fim da guerra em 5 de setembro e marcha para o Paraguai, onde permanece até sua morte em 23 de setembro de 1850.

Portugal dominou, até 1823, o território "oriental" que foi anexado ao Brasil Independente e se tornou conhecido como Província Cisplatina. Somente em 1825, quando os orientais começaram uma campanha militar contra o Império do Brasil, esse território voltou a fazer parte das Províncias Unidas do Rio da Prata. Somente em 1828, a República Oriental do Uruguai conquistou sua independência.

De maneira geral, ao se verificar o perfil de Artigas, por meio da leitura de uma historiografia atual, constata-se que o caudilho preocupa-se em recuperar a economia do território sob sua jurisdição, a revitalizar o comércio e a produção rural, além de atender a demandas sociais, mesmo que ao atender aos mais desfavorecidos economicamente tivesse a intenção de transformá-los em soldados.

A figura de Artigas parece ser bastante diferente do perfil do caudilho traçado pela historiografia liberal, que tem como grande representante Sarmiento, que tacha esse líder de ignorante e inculto, sedento de poder, sem um projeto de nação. No "Facundo", um dos clássicos da literatura histórico-ensaística argentina e mundial, publicado em 1845, Sarmiento dedica algumas linhas ao caudilho, tachando-o de "gaucho malo" e critica "los métodos de "muerte por enchalecamiento" que Artigas "inventara" y "legara" a Rosas". Porém, como sabemos, Sarmiento foi categórico e muito mais "bárbaro" que Artigas: para que a civilização imperasse algum dia naqueles descampados da Argentina 
era preciso primeiro derrotar o "gaucho". A sua plataforma (Sarmiento foi presidente do país entre 1868-1874) era expulsar a gauchada das províncias argentinas a tiro e a canhonaço, se fosse preciso; educar a juventude e importar gente européia para povoar o país. Contra isso, José Hernández rebelou-se. O manifesto do seu desagrado - o contrapondo ao Facundo de Sarmiento - foi o Martín Fierro.

De qualquer forma, Arregui sustenta, por meio do personagem vasco, em "El regresso de Odiseo González", uma visão de simpatia à causa de Artigas, o que comprova que o autor posiciona-se contra as duas coroas ibéricas que submeteram o Uruguai ao seu poder por muito tempo. Mas, não deixa de abordar o corte que a guerra faz na vida de Ranulfo, que é dividida entre o antes e o depois dela, já que no final, ao voltar para casa e ser aceito por sua mulher, o conto se fecha com um "y todo volvió a ser como antes de guerra". Essa visão do "gaucho" bucha de canhão remete ao Martín Fierro. Ranulfo, como Fierro, é o homem marcado por guerras, num contexto onde elas são regras e não exceção, já que as terras são disputadas por Portugal e Espanha, forças externas que comandam a vida desses "gauchos".

Por isso rememorar que o Uruguai ficou submetido a essas forças nos anos 1820 do século XIX, é rever o passado, para ficar atento aos acontecimentos do presente. Dada a devida distância, o Uruguai de 1972, momento da escrita de "El regresso de Odiseo González", prestes a ingressar em uma ditadura, pode aprender muito com o do início do século XIX, marcado pela arbitrariedade dos donos do poder. Assim, o panorama histórico que parece não ter importância no início do conto vai tomando corpo durante a narração, pois o narrador vai associando a vida de Ranulfo ao acontecimento do entrevero que determinava a vida dos homens. Entrevero esse que, no Uruguai de 1973, vai tomar a forma de uma ditadura militar e continuará a limitar a vida do "gaucho" em nome de uma lógica questionável que preza pelos interesses do capital internacional.

\section{3- "Los contrabandistas"}


Além de a vida dos "gauchos" ser cortada pelas guerras, ela também é marcada pelo contrabando, como demonstra o conto "Los Contrabandistas", publicado no livro Hombres y Caballos (1960). Esse conto é o terceiro do livro Cavalos do Amanhecer.

Como nos contos de Faraco a serem analisados adiante, Arregui demonstra que a situação do contrabando é uma constante na fronteira entre Brasil e o Uruguai, cuja região é notadamente marcada pela interação entre uruguaios e brasileiros.

As margens entre um e outro lado do rio Jaguarão é o espaço onde se desenrola a ação. Esse rio demarca a fronteira entre Jaguarão, no sul do Brasil, e Rio Branco, no Uruguai.

Ranulfo Alves, o chefe dos contrabandistas, juntamente com os seus homens, grupo em que se destacam os irmãos Juan e Pedro Correa, cruzavam o rio com alguns cavalos que carregavam bolsas, repletas de mercadorias. Na metade da travessia, quando se aproximavam da margem uruguaia, e Rulfo já planejava "llegar al anochecer a uma cerrillada donde conocía guraridas seguras, no lejos de cierto rancherío donde conocía guaridas seguras, no lejos de cierto rancherío donde había mujeres y donde, por añadidura, tal vez pudiera vender algo del mucho contrabando que traía", são surpreendidos pela patrulhas fronteiriças que "tiraban a matar". Os irmãos conseguem alcançar a margem brasileira. Ali, Rulfo é encontrado muito machucado. Os Correa tentam levá-lo até um português curandeiro. No entanto, Rulfo Alves, montado em uma mula, puxada pelos irmãos, têm delírios durante o caminho, uma vez que começa a conversar com os mortos, inclusive com aqueles que já havia assassinado. Juan e Pedro contagiam-se pelos seus dizeres. Para não enlouquecer, Pedro acaba por matar o chefe dos contrabandistas.

Um enredo que parece simples traz inúmeros implícitos. O que chama a atenção é o fato de o narrador onisciente reconhecer o contato e a interação entre uruguaios e brasileiros, explicitado pelo sotaque abrasileirado de Pedro:

"Los inseparables hermanos Correa parecían mellizos aunque no lo eran y montaban, esa tarde, dos bayos que parecían hermanos y tal vez lo fueran. Pedro llevaba prácticamente a remolque (con una cadena por cabestro) la mula vieja y ciega, medrosa de ríos y arroyos como toda mula. 
- Ganas de degollarla - había dicho con acento fuertemente abrasilerado."

O enredo demonstra o cotidiano daqueles homens que se identificavam com um e outro lado da fronteira, e os limites territorias tornam-se elásticos se for levada em conta a vivência desses "gauchos" e gaúchos.

Essa constatação pode ser comprovada quando Rulfo Alves é encontrado muito machucado na margem brasileira. E numa voz surda, porém autoritária, pronuncia uma só palavra: "las tres silabas del nombre de un português vastamente conocido en el pago, famoso por su habilidad para extraer balas com tenacillas de alambre o llamándolas a punta de cuchillo y para curar las heridas com agua fria”.

Note-se que, apesar de estar do lado brasileiro, ele encara aquele lugar como sua terra, seu "pago", unifica em uma única região tanto a margem esquerda como a direita do Jaguarão.

Apesar de no cotidiano inteargirem naquela região "sem fronteiras", reconhecem a existência do limite institucional que demarca um lado e outro. Ao fugir dos disparos dos policiais uruguaios, os irmãos Correas sabem que estão protegidos na margem brasileira:

“- Nos salvamos - dijo Juan com voz innecesariamente baja.

- No se vendrán a este lado? - preguntó y se preguntó Pedro.

- Digo yo que no... Aquí no mandan ellos."

Outro fato interesante que merece ressalva é a questão da heroicidade. Mas o que é o herói? B. Tomachevski define herói como um "condutor de motivos", mas esse autor considera uma outra possibilidade de conceituar o herói, quando trata da caracterização: "o personagem que recebe a tinta emocional mais viva e marcada é chamado de herói. O herói é o personagem que o leitor segue com mais atenção. O herói provoca compaixão, a simpatia, a alegria e o sofrimento do leitor." Tomachevski "esclarece, ainda , que a "tinta emocional" do herói está contida na obra, é construída, o que implica numa íntima relação entre a caracterização e o ponto de vista".

Em nenhum momento é construída uma imagem positiva, que acople destreza e valentia ao chefe dos contrabandistas. Rulfo Alves é tomado como um "hombre 
corpulento y de gran barba renegrida", homem violento, "temido que más de un hecho de sangre debía a cada lado de la frontera".

Já os irmãos Correa também não chegam a ser traçados por "uma tinta emocional viva". Aproximam-se de anti-heróis. Porém despertam uma certa "compaixão" do leitor, pois são caracterizados pelo narrador como homens que têm um medo extremo perante os delírios do moribundo Rulfo que conversa com pessoas já mortas. O narrador concentra-se na figura de Juan que começa a participar do monólogo e a enxergar os mortos também. Mas, de repente, a voz de Rulfo cala-se. Juan percebe que Pedro havia matado Rulfo:

“- Pedro!- exclama Juan.

Pedro levanta los ojos.

- Pero Pedro? ... - pregunta y reprocha Juan.

Pedro Correa mira el cuchilo y se dispone a envainarlo y dice:

- Hacete cargo de que si no lo tranqüilizo nos enloquece a los dos."

Um mundo marcado pelo "salve-se quem puder" é a situação presente no conto. E o narrador em $3^{a}$ pessoa, como observador, em momento algum deixa explícito ou fornece dados de que os personagens lamentam sua situação de "fora da lei" ou sua vida de contrabando.

Esse narrador do conto "Los contrabandistas" parece que "às secas" visa a mostrar a situação daqueles "gauchos" que pelo contrabando, pela vida rude, tornaram-se assassinos e nem sequer questionam sua condição e a arbitrariedade de tudo isso, por meio de um enredo que se encontra num passado não plenamente determinado. A única menção do tempo é estabelecida na seguinte passagem:

“ (Juan)Escuchó que Rulfo proseguía polemizando con el viejo Medina y que hablaba después con su hermano Antonio Alves y su amigo Vicente Suárez, degollado el uno y acribillado a balazos el otro en la penúltima guerra civil." 
Como sabemos, foram muitas as guerras que marcaram o Uruguai até 1876 e, pela constatação acima, percebe-se que a ação do conto se passa no século XIX, mas não é possível precisar com exatidão o tempo da ação.

\section{4- "Tres hombres"}

O conto "Tres Hombres" é o quarto conto do livro Cavalos do Amanhecer. Foi publicado pela primeira vez no livro Hombres y Caballos (1960).

Essa narrativa se inicia com uma fórmula tradicional do universo narrativo : "Había uma vez tres hombres". Em seguida, o narrador onisciente apresenta o primeiro dos protagonistas por meio de três dados individualizantes: seu nome "Ramiro Pazos", sua ascendência "hijo de españoles" e sua forma peculiar de falar "hablaba com um acento peninsular no del todo involuntário", o que sugere certo sentimento de superioridade em relação àqueles que o rodeiam em virtude de suas características serem ligadas à “civilização", às raízes européias. Mas, ele não é um “desambientado" no Pampa uruguaio, pois, há anos, desempenhava a profissão de comissário, numa vasta região rural. O lugar que Pazos governa é composto por vários ranchos de diversos tamanhos e é denominado “comisaría'e Pazos”, o que demonstra o poder que detém naquela região.

A ação se inicia quando Pazos recebe a visita de dois estancieiros fortes da zona, avisando-o que o Velasco andava pelo lugar. Então, é apresentado o sargento, de apelido Maciel, que segundo o narrador é "nuestro segundo hombre". Note-se que, novamente, por meio do possessivo estabelece-se uma relação de cumplicidade com o leitor por um possível narrador que desfia um caso.

Maciel é focado, em oposição a Pazos, como simpático, "de cara y sonrisa que le allanaban amigos".

No dia seguinte, seguem em busca do "fora da lei". Quase depois de três dias de busca infrutíferas, Maciel consegue informações sobre o "matrero" Velasco. Interessante observar que Faraco traduz a palavra "matrero", adjetivo que também caracteriza Martín Fierro, como "bandoleiro". Quando Faraco indaga qual seria a melhor tradução para esse adjetivo que qualifica Velasco, Arregui, em carta de 17 de março de 1982, responde: 
"El matrero es el elemento anárquico, individualista, en rebeldía solitaria. Es un fenómeno de protesta individual contra el orden feudal-capitalista instaurado ( o comenzado a instaurar) allá por 1870; es la reacción contra el alambrado. No es, me parece, asimilable al "cangaceiro" ni al "bandoleiro", aunque se parezca a los dos y aunque muy a menudo sea efectivamente un "bandoleiro". Aquí en el Uruguay hubo uno, "el clinudo Menchaca" (clinudo es la forma incorrecta de crinudo = pelo largo) que era un bandolero y asaltaba estancias al frente de una banda; pero no era un matrero típico."

Por essas observações, fica evidente que o "matrero" é diferente de um "ladrão", "bandoleiro", porque ele é gerado por um contexto histórico bem específico dos anos 1870, demarcado pelo cerceamento dos campos. É o "gaucho malo" de Sarminento, um bárbaro que vive a perturbar a "ordem"; é o homem resistente aos valores da civilização, aos valores dos estancieiros e do comissário Pazos. Assim, se Arregui caracteriza Velasco, como "matrero", significa que a ação do conto decorre, provavelmente, na época em que os alambrados tornam-se uma realidade no Pampa, ou seja, no final do século XIX.

Mas como o "matrero Velasco" é encarado por Arregui? Essa figura vai ser construída no decorrer do conto.

A primeira informação que alguns moradores da região oferecem sobre ele é que "andaba en un tordillo tirando a flaco y muy testerador", ou seja, é apresentada a descrição do homem em comunhão com o seu cavalo, figura que individualiza o "gaucho", o hábil ginete.

Ao longe, Maciel localiza Velasco. Ao atirar contra ele, o "matrero" se embrenha numa mata próxima para onde Maciel se dirige. Ambos desaparecem. Pazos não consegue alcançá-los, pois a natureza parece conspirar contra esse perseguidor convertendo-se em uma barreira intransponível: árvores e arbustos transfomam-se em "una intrincada maraña". Desiste da empreita e, como Maciel não retorna, resolve pernoitar numa estância de um inglês, localizada próxima do local onde se encontrava.

O encontro de Pazos com o inglês Greenstreet além de criar um espaço de espera, por deixar em suspenso a ação central do conto, mostra o enfrentamento de dois personagens que concebem a vida de maneira diferente.

Pela perspectiva do narrador onisciente, conhecemos o caráter solitário do inglês que recebe o visitante com "una hospitalidad resignada". Essa mesma onisciência descobre, por meio do olhar de Pazos, um mundo onde os objetos são surpreendentes 
por pertencerem a uma realidade distante da sua, um mundo onde a iluminação provém de "un farol de rara industria" e onde muitos pássaros dormem em jaulas.

Pazos pede a ajuda do inglês para localizar Velasco. Nesse momento, o descompasso entre os mundos das personagens chega ao clímax, porque o "civilizado" inglês afirma que em seu país só caçavam raposas:

“- Creo también que este no tiene caballo para ir muy lejos. Puedo contar con usted?

- No. En mi país cazamos zorros."

No dia seguinte, Pazos encontra com Maciel, que havia prendido o "fora da lei" ali perto depois de uma "peleia". Pazos, com ar de superioridade, deixa implícito que o inglês é quem deveria submeter-se aos seus costumes, ao ordenar ao capataz da estância de Mr. Greenstreet que o acompanhava:

"Vuélvase, don Eustaquio... y muchas gracias. Avise a los peones que no los necesito y digale al inglés que aquí no cazamos zorros sino matreros."

Maciel e Pazos foram ao encontro de Bráulio Velasco que se encontrava numa pequena clareira do matagal de costas no chão, com as mãos e os pés atados pelo maneador de Maciel. Perto dali, o cavalo de Velasco está preso e a meio do caminho entre ele e o cavalo, "em el suelo y como de nadie", está o seu punhal, que Maciel, com um golpe de faca, tinha feito cair da mão do adversário. Encontramos aí os três elementos fundamentais desse universo épico: o "gaucho", o cavalo e o punhal em desamparo, em virtude da perda da liberdade. Se o "gaucho" está preso desaparece a força de sua energia transmitida às coisas que o rodeiam.

Finalmente, os "tres hombres" do relato se reúnem. Os vencedores em sua postura privilegiada aparecem como "altísimos" diante da posição do vencido, quem, como gesto afirmador da sua liberdade interior que permanece, "desvio la mirada como si quisiera borrarlos".

O mundo somente existe quando é percebido, negar-se a ver e a ouvir é uma forma de desconhecer o que está ocorrendo e de anular o poder que os demais têm sobre ele. Esta conduta indiferente altera as ações de Pazos - "que era de la raza de los que golpean"- e marca o início de um duelo em que a obstinada resistência do matrero 
determinará um crescente de reações violentas do comissário e um enfrentamento final que decidirá seus destinos.

Pazos que visa submeter Velasco e, ao perceber que não é ele quem merece o mérito da prisão, começa a golpeá-lo. Num tom de arrogância, reproduz um verso presente em "Martín Fierro":

“- No hay matrero que no caiga"

O descendente de europeus evidencia que é muito mais "bárbaro" que o matrero que permanece em silêncio. A resistência de Velasco é silenciosa mas não passiva, já que sua energia é demonstrada nos lábios apertados e no olhar incisivo que crava no seu oponente, o que substitui seu punhal. Essa força, qualificada pelo narrador como "resistência primaria, elemental", tem o poder de converter ao "señor comisario Ramiro Pazos" em um "homem cualquiera". A violência física e verbal do comissário contrasta com a serenidade refletida no rosto impassível do "matrero". O descontrole de Pazos alcança o clímax numa agressão vulgar e humilhante: o comissário cospe em Velasco. Essa ação determina a degradação do comissário.

Maciel, que havia permanecido em silêncio, intervém, porque obedece a razão e a princípios éticos que o levaram a prender o "fora da lei". Não que vai se contrapor ao seu superior, mas seu sentimento de igualdade o solidariza com a situação do prisioneiro e o impulsiona a reivindicar a dimensão humana do "bandoleiro", submetido a um trato que o coisifica.

Quando Pazos volta a golpear o prisioneiro, Maciel arranca-Ihe a arma e decide soltar Velasco:

"Pazos retrocedió. Estaba desarmado: había dejado en el recado la bayoneta corta que era su arma blanca.

- Yo le dije que no destratara a este hombre - explicó Maciel. Yo lo prendí peliando... Ahora se lo voy largar...

Pazos quis avanzar.

- Atrás! - repitió el sargento, cambiando de mano la carabina y desenvainando el cuchillo.

El comisario fue rápidamente a recoger el puñal de Velasco; Maciel cortó el maneador; el matrero se puso de pie.

- Tendrá que prenderlo usté, comisario - dijo Maciel.

$\mathrm{Y}$, con movimiento casi ceremonioso, arrojó su cuchillo a los pies de Velasco. 
Y en seguida salió del calvero a pasos apresurados, apartando con la carabina las ramas de arbustos espinosos."

Maciel é um herói leal aos seus princípios, superiores à mera hierarquia. Então, afasta-se da cena do duelo e se senta à beira de um lago. Instantes depois, escuta passos que se aproximam. Vê o reflexo de Velasco na água. O "matrero" Ihe devolve a faca e diz:

“- A sus ordenes, Sargento - dijo la voz de Velasco.

Maciel siguió inmóvil y callado.

- Me entrego, sargento... Ordene - insistió la voz."

Assim, Velasco, em breves frases, submete-se porque ele também é representante de um código de honra que o eleva e o enobrece. É um homem que paga sua dívida a Maciel com a única moeda que possui: sua liberdade. Ao entregar-se, estabelece o seu código baseado na justiça e no respeito.

Supera-se, nesse momento, a visão de Sarmiento do "gaucho malo", porque supera-se o maniqueísmo que divide o mundo entre homens bons e maus, dada a complexidade das personagens.

Arregui fecha o conto evidenciando a cumplicidade conquistada entre os dois homens. O Sargento identifica-se com o universo de Velasco e lhe assegura a liberdade:

"Maciel no miro al matrero ni a sua imagen en el agua. Como para sí mismo, o como para nadie, o como para el mutismo de la laguna, o como para todos los hombres... pronunció:

- El zaino del finau es sin yel pa galopear."

Maciel e Velasco metaforizam o mundo de resistência dos valores uruguaios frente aos valores impostos por um poder arbitrário. Resistir, segundo Alfredo Bosi, é opor a força própria à força alheia. O cognato próximo é in/sistir; o antônimo é de/sistir. Mas quem resiste, nessa narrativa, não é a figura idealizada do homem do pampa, herdeiro de tradições gloriosas; é o "gaucho" ou o "paisano-gaucho" que lutam contra as situações mais adversas e sobrevivem frente à anulação e à superioridade da cultura espanhola, denotada, no conto, por Pazos.

\section{5- "Un cuento con un pozo"}


Resistir sempre ; esse é o lema do "gaucho" de Arregui, nem que para isso seja preciso matar, o que acontece no conto "Los Contrabandistas". Mas, muitas vezes, esse homem, em virtude de uma situação externa a ele, almeja à desistência, ao invés da resistência, como forma de sanar um universo de perguntas e necessidades que não podem ser respondidas.

É o que ocorre em "Un cuento con un pozo" um conto realmente impressionante por seu desfecho. Essa narrativa é considerada por Arregui um dos seus melhores contos. Foi escrita nos primeiros meses de 1969 e publicada em Tres libros de contos. Depois, foi novamente publicada em El Narrador (1972). É o quinto conto do livro Cavalos do Amanhecer. Aliás, Faraco, com o consentimento de Arregui, traduziu o título "Un cuento con un pozo" para "Cavalos do Amanhecer", título também escolhido para nomear a primeira coletânea de contos do escritor uruguaio traduzida e editada por Faraco no Brasil.

O narrador onisciente culto apresenta Martiniano Ríos, o protagonista, como um "gaucho que acostumabra a esperar el dia lavando morosamente un mate grande". Além de seus hábitos, também seus trajes são mencionados: "vestia todas sus prendas, desde las botas al sombrero de copa redonda; el cinto ancho e adornado con monedas no olvidaba el facón de acero español y tampoco el trabuco de caño corto, de fabricación francesa."

Essa caracterização tão precisa de Martiniano Ríos pode ser explicada pelo momento em que o conto foi escrito.

Em 1969, como já abordado anteriormente, quem governava o Uruguai era o autoritário Pacheco Areco. Seu governo permite a entrada definitiva do capital internacional americano, ou seja, é um momento onde o poder dos EUA começa a intervir mais diretamente nas relações econômicas, sociais, culturais não só no Uruguai mas também em toda América Latina. Nesse contexto, Arregui procura identificar os elementos que compõem a identidade do seu país. Retomar, então, a figura do "gaucho" com suas peculiaridades, que em muito contribuíram para a formação cultural do Uruguai é compreensível frente a uma ordem homogeneizante. No entanto, a retomada dessa figura não vai trazer à tona sua valentia, ousadia, coragem; mas sim a sua desmistificação. 
A tranqüilidade de Martiniano, naquele alvorecer, é quebrada pelo desasossego de seu cachorro, Correntino, que mais de uma vez tem que ser silenciado. O cachorro também acorda Josefa, esposa de Martiniano.

Josefa é descrita como "tristona y aindiada, con uno de esos cuerpos criollos muy de hembra que se tornam a la larga, siempre, un poco pesados".

Observa-se que, mais uma vez, ao caracterizar Josefa como "aindiada", ou seja indiática, Arregui reconhece que o índio, dizimado, repudiado, visto como selvagem, mesmo na obra Martín Fierro, constitui um elemento importante na formação do povo uruguaio.

Martiniano, se dá conta que a intranqüilidade de seu cachorro só poderia ser o presságio de algo ruim, "detectado por los sentido de brujería del nieto de perros cimarrones". Lembrou-se então que ouvira falar na "pulpería", perto da estância onde morava, da possibilidade de uma nova guerra civil.

Mesmo agitado, permanece esperando o clarear do dia, cuja descrição apresenta um grande lirismo; porém, diferentemente de outros contos, o narrador, embora culto, está mais em sintonia com os elementos do campo que rodeiam as personagens:

"El día nacía en el cielo con el lucero lo mismo que un ojo de caballo asesinado y estrellas que pánicamente huyen o naufragan, y en la tierra, en torno a Martiano, con la consabida vocinglería de pájaros en los talas y las cinacinas, con los balidos de sus vacas lecheras, con gallinas descolgándose de los aleros del galponcito y las ramas inferiores del ombú. Martiano esperaba sin saber qué esperaba y oyó iniciarse el coro de los teru-teros."

Além da maior intimidade com os elementos ligados ao mundo do "gaucho", o narrador, por meio das comparações ("El dia nacía en el cielo con el lucero lo mismo que um ojo de caballo" - "Estava nascendo o dia no céu, estava subindo a estrela d'alva como um olho de cavalo assassinado"), por meio de personificações ("y estrellas que pánicamente huyen o naufragan" - "e as estrelas em pânico fugiam ou naufragavam"), ligadas ao elementos da natureza, vai tecendo um ambiente macabro que se soma à agitação dos animais que rodeiam Martiniano. 
É pelo modo como voavam, como gritavam os "teru-teros", ou seja, os "quero-queros", que Martiniano começa a olhar na direção desses pássaros e se posta junto ao bocal do poço como uma coruja vigilante.

Nesse momento, quem ganha a cena é o poço, cuja descrição de "piedras bien calzadas y acunãdas" possui uma solidez que contrasta com a insegurança de Martiniano. Além disso, é descrito como "más viejo que los recuerdos: nadie en el pago podía aseverar con certeza quién había sido el voceador y menos aun explicar porqué había hecho un tal pozo en aquel lugar. (La tradición oral hablaba vagamente de un gringo y es muy posible que no se equivocara, porque lo criollo era el barril con ruedas o sobre una rastra, el sufrido petizo aguatero y la peregrinación al arroyo o la cachimba).

O fato de o poço ser mais velho que a memória e ter sido feito, muito provavelmente, por um gringo, um estrangeiro, já que não era costume daqueles homens conseguir água por meio da construção de um poço, mas por meio de um "barril com rodas" dirigido até uma sanga, remete à questão de aquele lugar ter sido habitado antes por gringos que impuseram seus costumes, estranhos à vida do "gaucho". Assim, na vida de Martiniano, não "existem pedras no caminho", mas existe um poço, elemento estranho a ele, mas que determinará sua vida.

Ao subir nesse poço, avista, naquele amanhecer, mais de cinqüenta ginetes que se aproximavam. Então, dirige-se ao rancho, acorda Josefa e Ihe diz que estava vindo outra guerra.

Já que, como Martín Fierro, conhece a situação difícil de ser arregimentado para uma guerra, pois já havia servido em duas, e ao acreditar que a função daquela patrulha era procurar soldados para um próximo embate, Martiniano fica desesperado.

Quando Josefa lhe questiona de que lado era a patrulha, Martiniano diz a cor da bandeira, como eram as divisas e acrescenta:

“- Me cago en todos. Yo no quiero." 
Saberemos mais a frente que aqueles homens poderiam ser "blancos" ou "colorados". No entanto, não fica explícito a que facção pertenciam, já que, para Martiano, não importava. O que ele não queria era servir outra vez.

Colorados ou Blancos são os dois partidos políticos que começaram a se definir no Uruguai a partir de 1820 e, apesar de, no decorrer da História, desdobrarem-se em outros partidos, alternaram-se no poder do Uruguai até 2005, quando Tabaré Vazquez do partido "Frente Amplio" foi eleito presidente . O partido Colorado, de modo geral, sempre foi ligado a um espírito mais modernizador, à criação de uma identidade "más ciudadana e inmigrante". Como conservador, caracteriza-se o "Blanco", cuja índole foi sempre mais "localista que cosmopolita", uma vez que se identificava "con el mundo rural".

Para Martiniano, são "farinha do mesmo saco", porque, tanto um como outro, estabelecem relações de poder autoritárias. Decide-se, então, apesar da objeção de Josefa que não esperava isso dele, esconder-se no poço. Martiniano ordena:

“- Decí que ando com tropa; escondé las espuelas y el poncho - terminó, levantando un poco la voz y yendo hacia la puerta.

Pero...- pretendió objetar Josefa.

-Haceme caso, mujer - dijo secamente Martiniano, saliendo del dormitorio."

Sua coragem, altivez, espírito livre escondem-se juntamente com a indumentária que tanto caracteriza o "gaucho-heroe"; o "gaucho" que com suas esporas comanda o cavalo na vastidão dos Pampas; o "gaucho" com o poncho a balançar junto ao vento. Martiniano só pensa em si; só almeja salvar sua pele. Sai do rancho e lá deixa Josefa e seu filho de apenas 8 anos. Caminha em direção a seu esconderijo: o poço.

Nesse momento, a ação é paralisada, para o narrador descrever a sensação daquele que desce às profundezas. É o narrador culto que metaforiza a descida não apenas de Martiniano, mas de todos os que enfrentam a sensação deprimente, distante da luz, de morte, de profundo desamparo. Surge, novamente, nessa narrativa, embora com mais sutileza, a presença de divagações que, embora não estejam entre parênteses, afastam-se da possível psicologia do protagonista. 
Martiniano, no fundo do poço, entra num estado de embriaquez, em virtude da falta de oxigênio. Volta a si quando o balde bate nele. Imagina que um dos ginetes estava com sede e iria beber água. Pensou que jamais subiria sem a corda. Inquietou-se, mas "se apaciguó o se entrego y se dejó llevar - el cuerpo aun más flojo, la cabeza doblegada, abatida sin interrupción alguna - por aquel tiempo que, simultánea o combinadamente, le hacía fraudes y lo olvidaba; y se dejó caer en un estado de gran desapego y de desesperanza al que no era ajeno un cierto bienestar indefinible."

Há uma crítica clara dirigida contra os homens que conhecem a realidade, mas preferem se alienar, conformar-se, num "certo bem-estar indefinível" perante a estrutura social vigente do Uruguai de 1969.

Martiniano, enfim, acorda com o ruído do balde, prezo à corda, que descia batendo na parede. Teve a quase certeza de que Josefa o jogara para dentro. Subiu com dificuldade de sua descida ao inferno.

A manhã ia já pela metade e os únicos seres vivos que avistou foram as galinhas que ciscavam no esterco deixados "por los caballos entrevistos al amanecer".

Pouco antes de chegar ao rancho, tropeçou no corpo de Correntino, degolado. Ao entrar, viu Josefa. "Estaba sentada y doblada, el mentón muy cerca de las rodillas, seguramente desnuda y cubriéndose con una frazada. Martiniano vio la cara, vio los ojos - y comprendió que muchos de los hombres de partida se habían turnado sobre ella."

O filho estava no catre conjugal, encolhido, o rosto oculto entre os braços, chorando baixinho. "Martiniano abrió la ventana y vio las salpicadura de sangre y no tuvo necesidad de mirar más para saber que el muchachito había sido castrado."

Martiniano desce novamente ao fundo do poço e se suicida com um tiro do seu revólver, porque deixa sua faca fora do poço, antes de descer. É um instrumento da "civilização", que tira sua vida, não a arma branca.

A "barbárie" da castração à criança, ao descendente de Martiniano deixa nas entrelinhas que um poder maior visa a castrar, a matar o embrião, aquele que daria continuidade ao "gaucho". Tudo isso pode ser lido como uma metáfora aos governos autoritários a que é submetido o povo uruguaio, o que Ihe tira a identidade, ou constrói 
identidades segundo a vontade das classes dominantes, que exaltam ou demonizam o "gaucho" conforme ele pode servir ou não a interesses claros.

Martiniano, por sua vez, apesar de ser vítima da situação, não é um herói positivo; é como qualquer homem que opta por um caminho, mas, depois, deve colher as conseqüências de sua escolha. É um homem, que frente à dominação, resigna-se e se esconde, o que vai custar sua própria vida e a de sua família. É um homem que não resiste às arbitrariedades. É a representação do Uruguai "destroçado e submetido à prepotência de governantes insensíveis e espoliativos."

\section{6- "Diego Alonso"e "Un cuento con insectos"}

Há personagens de Arregui, que, apesar de seu medo, de sua insegurança, resistem às adversidades, às forças que o acusam, e eles nem ao menos sabe por quê. É o caso de Diego Alonso, protagonista do conto que recebe o seu nome, publicado no primeiro livro de Arregui, Noche de San Juan (1956). Por meio desse personagem, tomaremos contato com o "gaucho" corajoso, que enfrenta as situações adversas que a vida Ihe apresenta.

O enredo do conto é simples. Diego Alonso vai a uma Barbearia do seu bairro. Chegando lá, o barbeiro o acusa de estar dormindo com uma certa mulher. Alonso não entende a acusação, pois responde que aquela mulher não diz respeito ao barbeiro. Mas este não se contém e o ameaça com um punhal. Ao perceber que está desarmado, Alonso foge. Quando chega em casa, embora com as mãos trêmulas, coloca sua faca na cintura e volta à barbearia. Pede, então, para que sua barba seja feita. Toda a tensão da cena é descrita minuciosamente, pois a navalha afiada do seu adversário passa duas vezes por toda sua face. No final, deposita no balcão as moedas pelo serviço e sai tranqüilamente na certeza de que "la raíz de donde puede nacer el coraje continuaba intacta"

Nesse conto, Arregui vai deixar vir à tona uma das qualidades que se liga à figura do "gaucho" dos Pampas: a coragem. Isso evidencia que Arregui, embora não queira que sua literatura seja associada a um certo tipo de "criollismo " que usa os atributos do "gaucho", como altivez, bravura, para escomatear a realidade de miséria em que vive, não nega a coragem, a necessidade de "lavar a honra" como uma característica de 
homens como Diego Alonso, um "paisano-gaucho", figura que demonstra bem o que restou dos homens dos Pampas sem cerca.

Como os personagens de Cyro Martins, Alonso vive num bairro popular e de periferia; vive em um "rancherío" . No primeiro parágrafo do conto, Arregui, por meio de um narrador em $3^{\circ}$ pessoa onisciente e culto, faz a seguinte descrição de Alonso:

"Era hombre que no llegaba a los treinta años, de estatura mayor que mediana, de piernas largas y torso bien calibrado. Vestía pantalón azul y camisa color ladrillo; pañuelo al cuelo y faja puntualizaban al hijo de un barrio de pueblo todavía con zanjones, caballos y yuyos."

Diego Alonso, embora não viva no campo, habita um bairro com todas as características da zona rural: "valões, cavalos e macegas" e sua heroicidade reside em enfrentar sua insegurança para voltar à barbearia e "poner en acción el coraje de que se sabía capaz."

A necessidade da coragem, tão pontuada pelo narrador, também pode ter a ver com o contexto em que o conto foi escrito. Em 1956, como já abordado em "Noche de San Juan", o Uruguai passava por uma grande crise, o que pode ter trazido para o personagem Reyles do conto "Noche de San Juan" o desamparo, a sensação de que algo estava errado. Porém, numa relação de oposição e complementariedade, essa crise também pode gerar a coragem para enfrentar as situações mesmo sob "o fio da navalha".

Pinceladas precisas compõem personagens, que trazem "os traços essenciais do homem do sul", sem cercá-lo de uma atmosfera mítica.

Mas, apesar de corajoso, esse homem também pode ser vítima da voracidade de seu desejo, o que acontece com Pedro Arzábal, personagem de "Un cuento con insectos", publicado em 1979, no livro La escoba de la bruja. Essa narrativa é a sétima

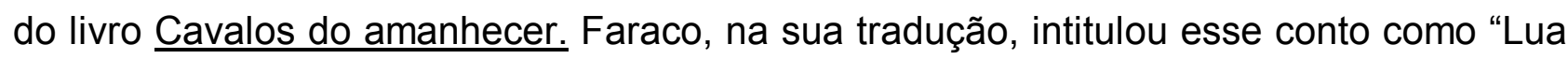
de Outubro".

Segundo Henrique de Freitas Lima, diretor e produtor do filme "Lua de Outubro" (1997), o título do conto de Arregui foi "rebatizado" por Faraco, porque o nome original "Un cuento con insectos" era "insosso". 
Luiz Antonio de Assis Brasil faz um comentário sobre o filme, que pode também ser transferido para toda literatura de Arregui:

“LUA DE OUTUBRO se inclui naquilo que podemos fazer de melhor: uma temática regional sem regionalices, tais como as que são praticadas por pessoas ingênuas que confundem o superficial com o conteúdo. A visão retrógrada do que seja regional faz com que o folclórico se resuma ao que tem de mais secundário: a fala, as roupas (ou fantasias), "as danças", etc; ora, isto é apenas uma abordagem leviana - há que procurar, antes de tudo, a psicologia do nosso povo, o que ele quer e deseja, seu modo de encarar a vida, a natureza, Deus e as instituições; enfim, o nosso modo de ser, e não o nosso modo de aparecer."

Um conto ambientado na região de fronteira entre Brasil e Uruguai é "Un cuento con insectos". Nele, não faltam a descrição da casa da estância, as conversas pausadas sobre o gado, que desvendam "o modo de ser" do "gaucho".

Há a predominância do narrador onisciente culto, que, em apenas uma passagem, assume a $1^{\text {a }}$ pessoa do singular, para deixar transparecer o narrador-autor que não só visa evidenciar sua presença, mas também seu controle total sobre os acontecimentos ("La noche de mi cuento no fue uma excepción”). Além disso, verifica-se, em alguns momentos, que a narração assume a $1^{\text {a }}$ pessoa do plural ("No tardo em dormirse, y no dudemos ..."; "Mientras Arzábal duerme y sueña suemos que no sabemos ..."; "Todos hemos sentido...") numa espécie de cumplicidade entre o narrador e o leitor, para que este se aproxime do narrado.

O narrador onisciente culto inicia o conto descrevendo a sala de jantar da estância "La alborada" de Don Marcial Lopes, que recebe a visita de Pedro Arzábal, capataz da estância vizinha.

A descrição traz para o leitor a ambientação de uma sala de estância, com os seus móveis, com uma lareira cujo consolo exibia troféus de exposição de gado. $\mathrm{O}$ tempo não é precisamente demarcado na narração que o coloca como um "tiempo de estancia".

O que chama a atenção é o elemento morte, que, sutilmente, vai aparecendo na descrição, para enredar a trama precisa do desfecho do conto: 
“(...) com uma no encendida estufa a lema cuya repisa exhibía trofeos de certámenes ganaderos, con cuadros al óleo en donde liebres y perdices muertas y colgadas de las patas parecían seguir muriendo interminablemente o estar fijadas en una muerte intemporal."

São apresentados os personagens: Dom Marcial Lopes, sua esposa, Dona Leonor, o filho do casal, a que chamavam Marcial chico e Pedro Arzábal.

Pedro fora à estancia "La alborada" conversar sobre o gado e outras coisas com Don Marcial e, como já começava a anoitecer, aceitou o convite do dono da casa para pernoitar ali.

A descrição novamente ganha a cena, para mostrar que a noite era de lua cheia de outubro, com um vento "tormentosoo presagiador de tormentas". E "la luna, al comienzo enorme y con tonalidades del rojo-sangre, se había levantado lo mismo que un ser vivo de las cuchillas brasileras o fronterizas, y ahora su círculo sin mella, más pequeño y restituido a su color de plata albina, alcanzaba la altura de las agudas puntas triangulares de la reja que separaba el patio del guardapatio."

Observa-se, nessa passagem, como Arregui, com maestria, localiza o espaço regional da ação do conto, ligado à lua. Tudo isso somado à descrição de outros elementos da natureza, como a dos insetos que rodeavam os lampiões, em noites como essas, e a do "Tata-Dios", ou seja, o "louva-a-deus", vai construindo uma ambientação ligada aos elementos encontrados numa estância, mas que trazem um certo estranhamento ao leitor pela precisão com que é elaborada:

"Y pudo verse tambiém, apareciendo parada como en un pedestal sobre la naranja que culminaba una frutera de mimbres y desapareciendo sin que nadie la viera irse, una elegante, espigada, bellísima mantis religiosa, el conocido mamboretá, voraz carnicero, cazador de hábitos diurnos pero que suele no desaprovechar una noche muy clara, insecto de más que tigresca ferocidad que es llamado comúnmente, a causa de sua actitud de acecho que parece la de un orante piadoso, Tata-Dios o El Profeta, y cuya hembra casi siempre asesina y devora al macho en seguida de la cópula." 
Quem vem jantar, e se juntar aos quatro personagens, porém sem dizer uma palavra, é niña Leonor, a primogênita do casal, considerada uma lunática por muitos. Era "la mujer más controvertida del pago, pero había algo en lo que todos - aun los que sólo la conocían de mentas - estaban de acuerdo: en aseverar su belleza, su "estampa de real hembra dibujada a pincelillo", según el dictamen oído por Arzábal de labios de un estanciero vizcaíno que era amigo de don Marcial."

Interessante notar que as mulheres, nos contos de Arregui, são pouco abordadas e, muitas vezes, vão aparecer como resignadas à figura masculina, o que ocorre com Dona Leonor que não se via no direito de se intrometer na conversa do marido, ou com a esposa de Ranulfo, que aceita o marido de volta com resignação no conto "El regresso de Ranulfo González ; como prostitutas ou "chinocas"; ou como uma espécie de "Teiniaguá", uma vez que desgraçarão a vida do "gaucho". Neste conto, haverá o predomínio da visão machista de Pedro em relação à niña Leonor visto que era um "hombre de treinta y pocos años de edad, era - desde siempre, desde su adolescência em um pueblo del sur donde las siestas de los patrontes dejaban como caza libre a las sirvientitas, donde las chinitas entraban em celo lo mismo que las perras y las prostitutas vestían ceñidos vestido de fulgurante -muy inquietado por la hembra". Pedro imediatamente sente um desejo louco por aquela mulher enigmática que deixa a sala de jantar sem dizer nada.

Os homens, depois da saída de niña Leonor, mantêm o diálogo por mais algum tempo. Em seguida, Marcial chico conduz Pedro ao quarto de hóspede, meio afastado da casa da estância. No pátio, os dois vêem e escutam niña Leonor uivar como uma vaca. Marcial justifica-se; "Está médio loquita, la pobre... Y ahora, fijesé usté... luna llena, viento norte..."

"Noite de vento, noite dos mortos". Esses dizeres de Bibiana em $\underline{O \text { Continente de }}$ Erico Verissimo, adequam-se perfeitamente à narração ("el viento norte sigue arrancando alargadas quejas..."). É o vento e a morte sempre a cortar a vida do gaúcho e do "gaucho". E o destino de Pedro está traçado: niña Leonor, no meio da noite, bate à porta e, sem dizer palavra, deita-se com Pedro; depois, foge às pressas. Como no enigma da esfinge, porque Pedro não a decifrou, apenas usufruiu do seu corpo, estava prestes a ser devorado. 
Quando já amanhecia, escuta novamente batidas na porta e a abre. Niña Leonor entra, e Arzábal vê, na mão da moça, o revólver dele, o qual deixara sobre a cômoda e de cuja subtração não se apercebera. Pedro tenta desarmá-la, mas ela começa a atirar:

"Los dos primeros y casi sumultáneo balazos abatieron herido de muerte a Pedro Arzábal; los otros tres, más espaciados, fueron un ensañamiento o por lo menos un exceso, sin duda alguna, las inexplicables mordeduras que el médico forense encontró en el cuello y el pecho de cadáver."

Como um "louva-deus" (nesse instante, fica esclarecido por que a descrição desse inseto foi trabalhada com precisão), ou como a esfinge, niña Leonor, que pode representar as forças que o "gaucho" não entende e nem busca compreender, devora-o. Metáfora, quem sabe, do período de ditadura militar que vivia o Uruguai quando o conto foi escrito (1979). Período em que as liberdades são suprimidas, as escolhas são "devoradas". É a literatura de Arregui que fala fundo ao homem de qualquer parte, mas que traz nas entrelinhas o contexto da ditadura uruguaia e da América Latina; é uma literatura que mostra o "gaucho" com seus desejos ardentes, com suas peculiaridades (Pedro Arzábal "sintió por el caballo una vaga ternura, um golpe de cariño, unas ganas como inconcretas de palmearle suavemente el anca."), com suas preocupações (Arzábal olha para as terras de Dom Marcial e constata que aquelas sesmarias de campo eram mal havidas, ou havidas não se sabia como), com suas superstições.

\section{7- "La escoba de la bruja"}

Revisitar costumes e superstições do mundo "gaucho", de fronteira faz parte do conto "La escoba de la bruja", publicado no livro de contos de Arregui que recebe esse mesmo título em 1979.

Esse conto é o oitovo do livro Cavalos do amanhecer e recebeu, na edição brasileira, o título "A vassoura da bruxa".

Interessante como Arregui inicia essa narrativa: 
"Para contar cierto tipo de historias hay que hacer algo muy parecido a cabalgar en la escoba de una bruja. Empiezo, escoba mediante, con un duelo a cuchillo que ocurrió allá por mil ochocientos setenta y tantos."

Mais uma vez, há a presença do narrador-autor que se manifesta em $1^{\text {a }}$ pessoa, justificando que esse "tipo" de narração, que vai estar recheada por costumes "gauchos", deve ser vista por meio de "um vôo na vassoura de uma bruxa". Assim Arregui não só demonstra que duvida do que será narrado, afinal a bruxa é uma criatura folclórica envolta em magia, susperstições, não realidade, mas também evidencia que tecerá uma narração cujos acontecimentos devem ser vistos de cima, por alguém que sobrevoa tudo, porém não aterrisa nesse mundo.

Arregui tem a necessidade de contar essa história, mas não endossa o acontecido como alguém que o presenciou de dentro. Como um escritor culto que é, não usa uma voz mais identificada com o contexto rural e fronteiriço. Logo, embora em alguns momentos volte a ressurgir essa voz em $1^{\text {a }}$ pessoa, esse conto também trará um narrador onisciente culto em $3^{a}$ pessoa, que conhece muito bem o universo narrado, porém não cede a voz ao personagem.

"La escoba de la bruja" traz o caso de um duelo de facas, cujo motivo não é esclarecido, entre o tropeiro Miguel Yuste e um tratador e variador conhecido por Paredes por volta de 1870.

O duelo é assistido pelos três filhos de Yuste, que é ferido de morte por seu adversário. Os dois filhos mais velhos tentam perseguir Paredes para matá-lo também, porém o irmão mais novo, Juan Pablo Yuste, impede-os "gritándoles, además de insultos, que el pobre finado había sido muerto em buena ley", o que evidencia o código de honra particular daqueles "gauchos" que não queriam que "la policia metiera el hocico." Paredes, depois de vencer o duelo, desaparece do "pago".

Logo depois da morte de Yuste, a narração segue com a descrição dos pormenores do seu velório:

"El velório se realizo al aire libre, bajo los árboles. Loshombres colocaron dos caballetes de desensillar y sobre ellos varias tablas y encima el cuero de la vaca recién sacrificada y encima el cuerpo de Miguel Yuste. (...)

No faltó caña para asentar el mate y, después, vino carlón para regar las achuras y, luego, más vino para empujar la carne asada." 
Também no conto "Lá no Campo" de Faraco, como veremos adiante, haverá a encenação dos rituais gauchescos, com sua roda de truco, com o mate, com a carne assada, presentes ainda hoje na vida dos homens da zona rural da fronteira (afinal, "começar um bom velório não são tão coisas de velhos assim").

Algum tempo após o velório, os dois filhos mais velhos de Yuste viajam com tropa e não voltam mais. Somente ali permanece Juan Pablo. E "transcurrieron años, muchos años: miles de días hechos de horas lentas y miles de noches rendidas al sueño (...) A lo largo de esos años se fueron muriendo los hombres que cierta tarde de primavera habían estado domingueando en cierta pupería, y la plural, compartida memoria del duelo, el velorio y el entierro fue como perdiendo puntos de apoyo con el decesso de cada uno, fue como hundiéndose de a pedazos en un olvido de algún modo emparentado con las piedras, las raíces del pasto, la redonda indiferencia del cielo, el no-recuerdo del tiempo sin pasado que fluye mentirosamente en los arroyos...”.

Em oposição à descrição da passagem inexorável do tempo que apaga as lembranças, o narrador vai assumir a posição daquele que detém a memória, o que sugere retenção da informação, conhecimento, experiência , quer em nível individual, quer social.

Dessa forma, se os homens não lembram o que aconteceu, nos anos posteriores a 1870, o narrador se recorda, para jamais ser esquecido que o Pampa sofreu profundas transformações:

"Durante esos muchos años hubo câmbios visibles en aquella patria chica: surgieron como por sí solas largas líneas de alambrado, crecieron geométricas plantaciones de eucaliptos que dieron al paisaje una verticalidad que no tenía, numerosas poblaciones de estancias de poco campo fueron abandonadas y descaecieron a taperas, se levantaron azoteas y casas de media-agua en cuchillas donde ni un árbol había o en substitución de los viejos ranchos..."

O narrador, depois dessas constatações, retoma a figura de Juan Pablo, que não se esqueceu do duelo. Ele permanece esses anos todos vivendo como esquilador, alambrador e posteiro. Era tranqüilo e firme "aunque acechado por uma abigarrada 
bandada de supersticiones". Ele, apesar de recordar do duelo e do seu desfecho trágico, não sabia o que estava por vir. Nesse ponto da narração, mais uma vez, surge a voz em $1^{a}$ pessoa e há a reprodução de um dos versos de Martín Fierro:

“...bueno, mi escoba se niega a adelantar la tardanza de lo que está por venir."

A utilização de um dos versos de Martín Fierro comprova a intertextualidade explícita, ou seja, a relação direta ou indireta de um autor com outro, o que vem pelo movimento e época literária, o que vem pelos pressupostos culturais comuns e o que é motivado pela situação sócio-econômica e política.

"La escoba de la bruja" é uma narração ambientada nos anos 1870, exatamente na época de edição do Martín Fierro (1872). Como na obra de Hernández, retoma a época do alambramento dos campos, do surgimento de taperas no lugar das pequenas estâncias que foram demolidas.

Além de a intertextualidade ser motivada principalmente para retomar a situação sócio-econômica e política tratada no Martín Fierro, que deve ser relembrada sempre, o verso de Hernández surge, no conto, no momento onde a voz narrativa assume a forma de $1^{a}$ pessoa, foco narrativo do Martín Fierro. Isso pode indicar que, como Fierro que conta o "caso" de sua vida, Arregui, com características ligadas a sua literatura, narra um "caso" de costumes e superstições "gauchas". Relembrar certos versos de Fierro, ditos cotidianamente na Fronteira, o que demonstra a abrangência e identificação com essa obra, é tornar pungente a memória popular coletiva, que, segundo Le Goff , cristaliza-se entre as populações por meio dos diversos grupos sociais de geração em geração, através da tradição oral. Retomar a memória popular coletiva é revisitar o modo de sentir desse povo da fronteira.

Além disso, Arregui, embora tome esse verso de Fierro ressaltando-o em itálico, em nenhum momento aponta de de onde ele proveio. Essa técnica de inserir segmentos de discurso de outros textos na continuidade da narração sem marca clara de onde retirou a citação é, como já observado, uma marca da ruptura com o "canón realista", técnica que Arregui já utiliza em seus primeiros contos. Sob técnicas bem precisas, Arregui vai compondo o universo pampeano e fronteiriço. Em sua literatura, forma e 
conteúdo se fundem para possibilitar um panorama "arreguiano" do que foi a vida do "gaucho".

E o "paisano gaucho", Juan Pablo, toma conhecimento de que o assassino de seu pai, trinta e tantos anos depois do duelo, estava de volta ao pago, já muito velho e debilitado. Paredes instala-se numa estância cujo capataz era um de seus irmãos. Falece pouco tempo depois, e seu velório acontece no galpão do lugar onde viveu seus últimos dias.

Então, o inusitado acontece: Juan Pablo chega ao velório, dirige-se ao fundo do galpão e, apesar dos muitos protestos, toma o cadáver e parte a galope com o corpo inerte de Paredes dobrado sobre o cavalo.

O narrador em $3^{\circ}$ pessoa afirma que muito foi dito depois do acontecimento, mas não houve quem fosse capaz de formular sequer uma aproximação daquela frase antiqüíssima "(nacida en la costa oriental del Mar Egeo hace casi veinticinco siglos) que asevera que nadie queda tan unido a nadie como el homicida al victimado".

Por essa afirmação, o narrador justifica a atitude de Juan Pablo, que enterrou Paredes ao lado de Yuste, o que pode ser comprovado pela existência da terra removida e pela aparição de mais uma cruz de madeira muito junto à cruz do pai de Juan.

Juan Pablo é supersticioso, mas Arregui deixa nas entrelinhas que ele não herdou certas crenças apenas do universo "gaucho", mas também de uma cultura universal, nascida há quase dois mil e quinhentos anos. Regional e universal fundem-se, para resgatar o modo de ser dos habitantes do Pampa fronteiriço.

\section{8- "Los ladrones"}

"Los ladrones", publicado pela primeira vez, em La sed y el agua (1964), narra um acontecimento na vida de Mariano Gómez e Alejandro Rodríguez, "muy amigos, y ladrones o aspirantes a ladrones". Eles resolvem roubar o italiano Orsi, o padeiro solitário e avarento daquele bairro mais miserável da cidade.

O que chama a atenção no conto é a questão de os costumes do "gaucho", como tomar chimarrão, serem retomados. No entanto, o narrador onisciente culto em $3^{\circ}$ pessoa, em nenhum momento relembra que provavelmente Mariano e Alejandro 
migraram do campo para compor os cinturões de misérias dos bairros periféricos das cidades do interior.

E, como muitos outros uruguaios, acalentavam o sonho de ir para Montevidéu. O objetivo era migrar para a capital e viver "sin trabajar ni robar" , meta que seria concretizada com o dinheiro do roubo. Gómez resumia seu sonho em um comentário:

“-Yo quiero ser rico pa no ser pobre - simplemente decía."

Esperam a noite chegar e se dirigem para o galpão onde o padeiro trabalhava. Ficam espiando Orsi pela janela. Entrariam assim que ele dormisse; colocariam vendas no seus olhos e em sua boca; fugiriam com o dinheiro.

Porém, ao observarem todo o labor do padeiro pela janela, são surpreendidos pela pela seguinte cena: Orsi, depois de encher os cestos de pães que seriam vendidos no dia seguinte, com uma porção grande de massa, começa a sová-la sobre a mesa e esculpe nela o formato de uma mulher. No final "el panadero tomo dos panes calientes y lês arrancó la cáscara y amasó con la miga una bola en la que hundió a fondo los dedos para hacercele una hendidura; después la cható un poco y la colocó, presionándola cuidadosamente, en la entrepierna de sua mujer de masa."

Ao perceberem a situação, Mariano e Alejandro sentiram que continuar ali seria um ultraje a algo ou a alguém. Numa atitude de respeito ao outro, os fracassados aspirantes a ladrões, retiraram-se "definitivamente" da janela.

Essa narrativa é a última da edição brasileira Cavalos do Amanhecer. Isso pode ser compreendido porque é uma espécie de panorama da vida de muitos "gauchos" da atualidade, jogados na miséria.

Também nesse conto, vai surgir a $1^{\text {a }}$ pessoa do plural, principalmente nos momentos em que Arregui refere-se às personagens:

"El plan de nuestros amigos era de lo más sencillo." 
"El plan se iba cumpliendo; nuestros amigos permanecieron agazapados e inmóviles"

"No es improbable que Alejandro y Mariano hayan muerto; si así fuera, podemos asegurar con toda convicción que vivieron y murieron sin conocer el significado de la palabra "alquimia"."

Essa técnica, como nos outros contos onde ela é apontada, visa aproximar o leitor do universo narrado. No entanto, o narrador deixa bem claro, como verificado no último exemplo, que tem o total domínio sobre o enredo, porque os acontecimentos já se encontram num passado. Além disso, ele faz questão de mostrar que é culto, ao anunciar a restrição de conhecimentos das personagens.

Mas "por encima de estas ignorâncias", Alejandro e Mariano conservam valores, como o respeito ao outro, que transcende o lucro. São "gauchos" jogados numa situação de ninguendade, num momento (anos 60) em que se inicia o projeto de liberalização no Uruguai. São "gauchos" "para quien pobres y hombres significaban casi lo mismo". Mario Arregui retoma, de maneira muito particular, a vida desses homens e constrói um perfil do "gaucho" ou do que restou dele a partir da segunda metade do século XX. Também muitos contos de Faraco, a serem analisados a seguir, retomam essa figura. 


\section{SERGIO FARACO}

\section{1- Sergio Faraco e sua obra}

"- É preciso compreender as pessoas, gostar delas. Um escritor sempre pensa que vai salvar alguém de qualquer coisa."

Esta reflexão está presente no conto "Sesmaria do urutau mugidor" e faz parte das observações do personagem-narrador, um escritor que está mudando de Porto Alegre para Uruguaiana, mas que acaba se perdendo nas estradas do pampa.

Por trás dessa voz narrativa há, indubitavelmente, a de Sergio Faraco, escritor comprometido com uma literatura que dá a ler o movimento do social desvendando-se na formalização estética.

Partindo da perspectiva de que Sergio Faraco trabalha com uma intenção fundamentalmente artística, embora não deixe de contribuir ocasionalmente para propósitos políticos ou sociais reivindicatórios, analisaremos seus contos fronteiriços, escritos durante e após os anos 1970.

Esses contos compõem a primeira parte do livro Contos Completos, cuja primeira edição é de 1995, e a segunda é de 2004. Interessante notar que essa obra foi dividida em três partes por desenvolver três focos temáticos diferentes.

A primeira parte é composta por contos que retratam a vida do campo num mundo localizado na região da fronteira que está prestes a desaparecer. Mas ali ainda vivem "gaúchos da cepa" conservando as tradições. Também enfocam a vida daqueles que sobrevivem na periferia das cidades da fronteira e vivem do "chibo" ou contrabando, numa ordem muito particular de lealdade e coragem.

A segunda parte dos Contos Completos retrata os sustos, as descobertas que ocorrem na infância e na adolescência. São contos que revelam uma experiência única, repleta de prazeres e dores. Durante a leitura dessas narrativas, mergulha-se no universo da criança e do jovem e se sente ecoar a voz do narrador que, nas entrelinhas, reitera o dito de Machado de Assis: "o menino será o pai do homem".

Já na terceira parte, a periferia da cidade grande é colocada em cena. São contos que desvendam o cotidiano dos desempregados, dos velhos, dos homens solitários que questionam a sua vida e se sentem oprimidos frente ao cotidiano urbano massacrante.

Sem dúvida, é de grande utilidade para a crítica quando são reunidos praticamente todos os contos de um escritor em um livro e uma ordem é estabelecida para as 
narrativas, principalmente com a aprovação dele. Dessa maneira, já que o objetivo é verificar como o gaúcho da fronteira do Brasil, moldado sob o estereótipo de valente, guerreiro, desbravador de fronteiras, é retomado na literatura de Faraco, interessam, sobretudo, os textos da primeira parte do livro Contos Completos.

Contista por excelência, Faraco publicou seu primeiro livro, Idolatria, em 1970, mas nele não havia nenhum conto "fronteiriço". Apenas, no seu segundo livro, Depois da Primeira Morte, em 1974, surgiu “Travessia”, primeiro conto que vai abordar o cotidiano do homem da campanha, morador da periferia das cidades fronteiriças, que tem como principal atividade o contrabando. Essa narrativa foi incluída na antologia de Os melhores contos brasileiros de 1974.

Depois surge, em 1978, Hombre. O conto "Travessia" faz novamente parte do repertório desse livro, além de surgirem outros contos fronteiriços, como "O massacre do Bugio Amarelo", "Hombre" e "Sesmarias do Urutau Mugidor".

Em 1984, é lançado Manilha de espadas, cuja primeira parte é composta por cinco contos "fronteiriços": "Aventura na sombra", "Dois guaxos", "Manilhas de espadas", "Guapear com frangos" e "A voz do coração".

Em Noite de Matar um homem (1986), são publicados 12 contos e todos elegem o pampa como espaço para o desenrolar da trama. Com exceção de "Lá no Campo", "Noite de matar um homem", "O vôo da garça pequena", "Adeus aos passarinhos" , os outros oitos contos já haviam sido publicados em edições anteriores: "Dois Guaxos", "Manilha de espadas", “A voz do coração”, "Guapear com frangos”, publicados em Manilha de espadas; "Travessia", publicado pela primeira vez em Depois da Primeira Morte e depois em Hombre; "Massacre do Bugio Amarelo", "Sesmarias do Urutau Mugidor" e "Hombre", publicados em Hombre.

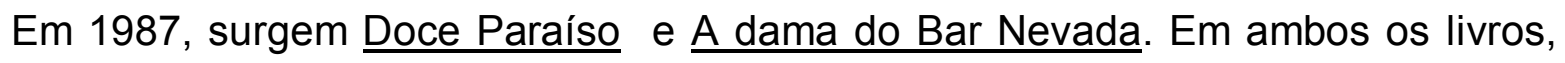
como numa espécie de compensação ao anterior, Noite de matar um homem, não há nenhum conto de vertente regionalista.

Em Majestic Hotel (1991), com exceção de "Aventura na sombra", já publicado em Manilha de espadas, nenhum texto vai adensar, por meio do conteúdo e da linguagem, o cotidiano do homem da fronteira.

É lançada, em 1995, a primeira edição dos Contos Completos. Foi nessa época que Faraco declarou que iria parar de escrever, pois sentia que seus contos já não correspondiam ao que ele julgava ser o seu melhor. Numa entrevista a Paulo Bentancur 
da Revista Vox, em 2000, o entrevistador indaga se surgiram alguns contos depois dessa declaração. O escritor gaúcho diz que nunca se resignou e então não deixou de tentar, mesmo nos primeiros anos noventa, quando sentar à sua mesa lhe dava sono, tédio ou náusea. Assim, escrevia e rasgava. Esses contos são, para seu gosto, meras tentativas. A diferença é que não rasgou.

Depois de 1995, são publicados dois livros de contos: Dançar tango em Porto alegre e outros contos escolhidos (1998) e Rondas de Escárnio e Loucura (2000). O primeiro faz parte da série "Pocket" da editora L\&PM e se configura como uma espécie

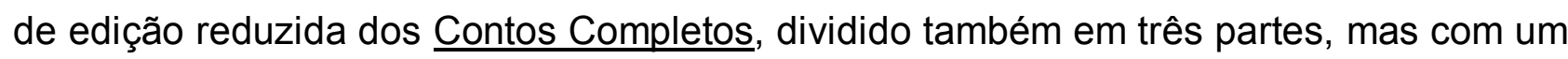
menor número de contos em cada uma delas. O segundo é composto por 11 contos também tomados dos Contos Completos, porém nenhum possui a temática "fronteiriça".

Algo curioso que poucos notaram, como já observou Paulo Bentacur, na entrevista de 2000, é que se pegarmos todos os livros de contos de Faraco, sempre há algumas narrativas que se repetem de um volume para outro, o que configura uma forma original de organizar as coletâneas. Então, o entrevistador questionou ao escritor qual exatamente era a intenção disto. Faraco respondeu que não era deliberado, não existia uma intenção. Se republicava um conto era porque, considerando-o deficiente, tentava melhorá-lo. Nos Contos completos, modificou todos os cinqüenta que ali estão. Três anos depois, em Dançar tango em Porto Alegre, aproveitou a oportunidade para melhorar o que podia. São modificações nem sempre perceptíveis: um ponto que troca de lugar, supressão ou substituição de uma palavra indevidamente repetida, orações que se sintetizam ou cuja tônica precisa ser deslocada e assim por diante, para fazer do conto uma peça harmoniosa e natural. Escrever, para ele, é esse afã de dizer com melodia.

\section{2- A literatura gauchesca no Rio Grande do Sul nos anos 1920}

Indubitavelmente, os contos fronteiriços de Faraco são harmoniosos e naturais. $E$ a qualificação de gauchescos e regionalistas também caberia a eles? No Brasil, existe ou existiu literatura gauchesca?

Chiappini afirma que "pensando apenas na produção narrativa em verso, concorda-se, na linha inclusive de Donaldo Schüller, que não houve no Rio Grande do 
Sul, até o final do século XIX, esse tipo de produção porque dominou aí o canto da monarquia, que, no limite, é o contrário do canto do gaúcho marginalizado e do realismo de um Hernández. Mas se pensamos depois disso, surge algo que começa com Antonio Chimango, na linha da poesia satírica. E, mais, se integramos na gauchesca a prosa, como faz do lado argentino quem nela coloca um Güiraldes, aí entrarão outros pontos altos da literatura riograndense, híbrida, colidante, como diria Ángel Rama, de um João Simões Lopes Neto a um Cyro Martins, de um Aureliano Figueiredo Pinto, com o romance Memórias do Coronel Falcão, ao Érico Veríssimo de O Tempo e o Vento."

É também Ligia Chiappini Moraes Leite que em Regionalismo e Modernismo (O "Caso" Gaúcho) faz uma análise demonstrando que nem sempre a gauchesca realista e de cunho social de um Hernández prevaleceu no Rio Grande do Sul. Em muitas obras (entre 1900 e 1930) vigora uma literatura que, em termos ideológicos, assemelha-se à gauchesca do período de Rosas.

Essa pesquisadora faz, nessa obra, uma análise de nove livros de textos em prosa (No Pago, de Clemenciano Barnasque (1925); Quero-Quero, de Roque Callage (1927); Querência, de Vieira Pires (1925); Pampa, de João Maya (1925); No Galpão, de Darcy Azambuja (1925) ; Tapera, de Alcides Maya (1925); Alma Bárbara, de Alcides Maya (1922); Contos Gauchescos, de João Simões Lopes Neto (1912); Casos de Romualdo, de João Simões Lopes Neto (1914)) . Essas obras servem, no limite, à “ ideologia da classe dominante, à qual interessa, no momento, a projeção do gaúcho a herói nacional", estimulando "o mito da igualdade do gaúcho nas estâncias , o mito da democracia no campo.". Segundo Mario Maestri, o gaúcho, nesse momento, é transformado em um hermafrodita, pois ele foi ideologizado para possuir "os atributos não contraditórios do fazendeiro e do peão"

O que prevalece, então, é uma essência heróica, o que não permite aos autores fixarem-se no gaúcho de 1920, com todas as transformações sociais e econômicas que a zona pecuária, espaço onde ele habita, sofreu, principalmente a partir das últimas décadas do século XIX. "A percepção do presente é permeada pela evocação do passado". É uma literatura que, como a gauchesca dos primeiros tempos, maneja o pensamento do presente por meio de "personagens caracterizados em função de uma idéia que se tem do homem do passado".

Entretanto, esse mito do herói gaúcho não é um "simples capricho de letrados", mas está historicamente determinado. A partir da década de 1920, também ganhou força 
a historiografia sul rio-grandense de vertente lusa, cujo objetivo era negar as trocas com a área pratina. "Aurélio Porto é posto como o lançador dessa tendência historiográfica que se intensifica a partir dos anos 20; Souza Docca dá continuidade e desloca o discurso, tornando-o mais convincente; Othelo Rosa expande e aprofunda a matriz lusitana; cabendo a Moysés Vellinho seu aprimoramento lingüístico e literário, finalizando sua trajetória." Era uma historiografia que criava uma identidade lusitana para o Rio Grande do Sul e insistia na existência de sentimentos brasileiros no Estado. Assim, "ao discurso político da década de 1920, que depositava esperanças no futuro do Estado no comando nacional, agregava-se o discurso histórico que patenteava a nacionalidade brasileira dos gaúchos", negando as influências do Prata, embora muitos desses historiadores, ao mesmo tempo que privilegiavam a origem lusitana do Rio Grande do Sul, apresentavam-se muito próximos da matriz pratina.

Aurélio Porto é um exemplo. "No texto "Influência do caudilhismo uruguaio no Rio Grande do Sul”, de 1929, afirmava que grandes semelhanças ligavam o sul à pátria de Artigas (Uruguai), desde as origens da formação inicial à comunhão de usos e costumes, "quase a mesma fácies geográfica”, a própria língua, identificando a raça, o espírito cavalheiresco e a vida heróica . Reconhecia a existência de interesses opostos levando a lutas entre si, depois das quais, reaproximaram-se rio-grandenses e uruguaios. Exemplificava a proximidade e a amizade entre rio-grandenses e uruguaios, apontando gaúchos da cidade de Rio Pardo, no interior do Rio Grande do Sul, que participaram das lutas de independência da Banda Oriental. Neste mesmo texto, também identificou a existência do caudilhismo no Uruguai e apenas tendências no Estado, com poucos elementos tomando esporadicamente atitudes caudilhescas."

No entanto, o que realmente se pode apreender dessa época é o esforço continuado dos rio-grandenses para se afirmarem como brasileiros, num contexto paradoxal em que ainda ressoavam os objetivos separatistas da Revolução Farroupilha, como defendido por Alfredo Varella. Era preciso "convencer" a nação das qualidades do gaúcho que lutou com determinação para continuar a ser brasileiro, já que a classe dominante se encaminhava para disputar o poder central contra São Paulo, e só homens "de cepa" poderiam governar o país.

Esse discurso político não só presente nas obras historiográficas como também em um certo número de contos, publicados nas duas primeiras décadas no Rio Grande do Sul, procuram exprimir uma mensagem: "o mito do gaúcho herói." E "essa imposição 
tem muito a ver com a crise da economia cafeeira no país, o enfraquecimento das Oligarquias e a cisão da aliança café-com-leite no poder Central; a ascensão de novas forças econômicas e políticas no Estado Gaúcho; o clima de euforia aí predominante e a confiança na conquista breve do Brasil pelo Rio Grande, sonho longamente acalentado pelas elites gaúchas, cujo papel econômico e político no País sempre foi secundário."

\section{3- O "projeto literário" do "mito do gaúcho herói” e Simões Lopes Netto}

No livro Regionalismo e Modernismo (O "Caso" Gaúcho), Ligia Chiappini traça todo o contexto que levou muitos escritores das primeiras duas décadas do século XX a escreverem uma literatura que serviu aos interesses da classe dominante rio-grandense.

O estudo também sustenta a tese de que ao visarem à transmissão da mensagem do "gaúcho-herói", não houve renovação da prosa, mesmo diante do advento do Modernismo no Brasil, pois os textos analisados seguiam as tendências da prosa regionalista, praticada não só no Rio Grande do Sul, mas também no Brasil, pelo menos na fase anterior a 1930. As peculiaridades desse gênero são: "1. o descritivismo; 2. a redução do personagem a tipo (sobretudo pela transferência de qualidades da natureza para o homem) e a conseqüente idealização na tipificação extrema - do gaúcho-herói ; e, finalmente, 3. a visão exterior, o foco narrativo distanciando, com a necessária ruptura entre narrador e personagem (agravada pelo gosto de fazer estilo, pela eloqüência das páginas antológicas). Essas três características, devidamente exploradas e problematizadas, parecem suficientes para delimitar o modelo de prosa regionalista."

Para Mario de Andrade, por exemplo, "Regionalismos é mate aqui, borracha ali... pobreza sem humildade, caipirismo a saudosismo, comadrismo que não sai do beiço e o que é pior, se contenta com o beco (...) não adianta nada nem para a consciência da nacionalidade. Antes a conspurca e depaupera-lhe estreitando por demais o campo de manifestação e, por isso, a realidade. O regionalismo é uma praga antinacional."

Contudo, dentro desse panorama, como observado por Ligia Chiappini, destaca-se a figura do escritor rio-grandense Simões Lopes Netto (1865-1916), que renova as tendências do regionalismo. Foi um escritor que encontrou "outro fio, para relembrar o 
passado do gaúcho, talvez com maior verossimilhança: a fala e o gesto do narrador popular", uma vez que não tinha dificuldade em ceder a voz ao homem do campo em livros que modestamente chamava de "populário": Cancioneiro Guasca (1910), os Contos Gauchescos (1912), as Lendas do Sul (1913), os Casos do Romualdo (obra póstuma, publicada em 1952).

Nos seus contos, não há a barreira cultural que existe entre o narrador e o seu objeto. Nos Contos Gauchescos percebe-se “a interiorização do foco narrativo". Há a visão de dentro do universo narrado, através da narrativa em primeira pessoa. A dificuldade que os regionalistas dos anos 20 tinham em "delegar a palavra ao personagem é inteiramente superada. Destrava-se a palavra; destrava-se a narração. Simões Lopes, o narrador culto, delega a palavra ao narrador popular, Blau Nunes, protagonista ou testemunha dos casos que conta, representante autêntico desse mundo. Supera-se totalmente a ruptura narrador-personagem. E como o olhar que enfoca a paisagem e as pessoas é o olhar interno ao seu universo, supera-se o pitoresco; vence-se a distância entre o narrador e o seu objeto, porque o narrador renuncia ao seu posto de detentor da palavra e da verdade. Os esquemas cultos que se superpunham ao objeto para interpretá-lo são agora substituídos pelo senso-comum de Blau Nunes, representando um consenso coletivo."

Assim, "o fenômeno da modernidade de Simões Lopes e da qualidade dos seus contos, tem muito a ver com a consciência do escritor que ele precisa ter; consciência e conhecimento dos seus materiais, (isso inclui técnicas e temas, bem como a adequação entre ambos) e da sua função na sociedade. Dessa consciência parece derivar o interesse pela linguagem popular que assimila e estiliza."

A opção pelos dominados vai aparecer na ficção "lopes-neta", já que, como discorrido, o escritor culto cede a palavra ao peão de estância, Blau Nunes, narrador e personagem dos contos. Simões Lopes possui "uma postura crítica e lúcida contra o culto do progresso, a degradação da natureza, a substituição do valor de uso pelo valor de troca, atingindo vidas humanas e animais, degradados todos em mercadoria. Faz parte dessa crítica ao progresso uma defesa do nacional sem xenofobia, contra a simples "macaqueação" do estrangeiro. Assim, se por um lado aceita as transformações do progresso, lamenta a implantação de hábitos e costumes em desacordo com nosso temperamento, o nosso clima." 
É um escritor que "busca o novo por um trabalho com a tradição" e "propõe-se a conhecer melhor a realidade brasileira, valorizando o folclore, as falas regionais, o "fundo étnico dos costumes."

Podemos concluir que Simões Lopes é um dos escritores pioneiros em pensar uma mediação entre o regionalismo e o modernismo que estourou no Brasil, em 1922, com a Semana de Arte Moderna de São Paulo e se estabeleceu como um movimento, dizia-se, de libertação dos velhos conteúdos mitológicos e das formas rígidas, da contagem das sílabas a ponta de dedo, da rima e da camisa de força do soneto. O Movimento de Vanguarda, ou Modernismo, chegou com o objetivo de repudiar a ordem estabelecida, a fim de instalar o novo no terreno das Artes. Fez-se presente, sobretudo, na literatura que almejava a uma ampla renovação dos modelos eurocêntricos estabelecidos anteriormente.

Já Ángel Rama afirma que na América Latina essa mediação aparece nas obras de José María Arguedas, Juan Rulfo, Augusto Roa Bastos, João Guimarães Rosa, Gabriel García Márquez. No Brasil, João Guimarães Rosa estabelece um trânsito entre os elementos mais reservados e íntimos de uma cultura regional, como os que estão imersos na língua e que permitem a partir dela um reconhecimento estrutural da visão de mundo, e uma composição artística disciplinada pelas correntes modernas da narrativa. Portanto, Guimarães Rosa não vai se pôr a salvar tradições ameaçadas, mas sim superar bases estilísticas que estavam em via de se esclerosar pela formulação de um modelo único. Seu tema, seus personagens, cenários, situações narrativas não se afastam muito dos praticados pelo regionalismo, no entanto, parecem inteiramente diferentes, porque a novidade das contribuições técnicas traduz coerentemente uma cosmovisão completamente diferente.

O regionalismo de Rosa, segundo Pablo Rocca, já não mais distancia a forma do representado, mas incorpora o falar oral à voz do narrador, contribuição técnica que traz o novo, tão almejado pelos modernistas.

Nem Rama, nem Rocca, citam as obras de Simões Lopes, mas ao descreverem a literatura de João Guimarães Rosa ecoam "técnicas literárias" já usadas nas obras do escritor rio-grandense. Daí podermos concluir, como Ligia Chiappini, que "ao incorporar a fala popular e ao fazer uma utilização assimiladora do folclore gaúcho, Simões Lopes é um dos precursores do Modernismo Brasileiro, do Nacionalismo crítico que Mario de 
Andrade propunha e, de forma mais remota, daquilo que Antonio Candido chamou de Super-Regionalismo, embora, é claro, existam distâncias muito grandes, entre a sua obra e a de Guimarães Rosa, como nem poderia deixar de ser."

\section{4- De João Simões Lopes Netto a Cyro Martins}

Depois dos anos 1920, o escritor que se destaca no panorama literário rio-grandense é Cyro Martins.

Seu primeiro livro de contos, Campo Fora (1934), ainda é tradicionalista, pois traduz "a vida briosa da campanha: as carreiradas, as gauchadas, os causos de galpão, os tesouros, as assombrações". Mas a fantasia de Campo Fora cede lugar à amarga realidade do "gaúcho a pé", expressão que usou pela primeira vez em 1935 e serviu para fazer referência à trilogia composta por Sem rumo (1937), Porteira Fechada (1944) e Estrada Nova (1954).

Escreveu esses romances à luz de um contexto em que "os temas de proporções épicas não correspondiam mais à realidade da desalentadora década de 1930/1940. Os temas clássicos do regionalismo estavam gastos e estereotipados e Cyro Martins trouxe à tona a transição da estrutura econômica, política e social" dessa época, uma vez que os anos 1930 marcam a entrada definitiva do capital industrial no Rio Grande do Sul, o que põe em xeque o poder político e econômico dos estancieiros, apesar de a estrutura fundiária permanecer inabalável.

O controle político e econômico da região da Campanha pelos "donos" desse território ficou mais evidente a partir de 1828. Desde que o Uruguai, "co-irmão gaúcho histórica e culturalmente, havia sido transformado de província Cisplatina em República Oriental do Uruguai, a Campanha começa também a revelar abertamente seu potencial autonomista. Configurada em 1828 como parte efetiva do Estado-nação brasileiro e diante de seus vizinhos uruguaios, então libertados do jugo imperial, a Campanha (ou o próprio Rio Grande do Sul), em sua identidade social, econômica e geopolítica, acabaria também por organizar-se politicamente, reivindicando para si uma autonomia como a que fora outorgada aos orientais." 
De 1830 a 1870 houve a consolidação do poder político e econômico dos estancieiros, e o espaço da Campanha, com a criação de gado e com as charqueadas, impõe-se no panorama regional e nacional, e se confunde com a própria província do Rio Grande do Sul, pois essa área de pecuária extensiva era, na época, a única economicamente integrada ao poder central.

Contudo, já no final do século XIX, notava-se que o rebanho bovino do Rio Grande do Sul, em virtude da concorrência pratina, da perda das vantagens aduaneiras a partir da queda do Império, da violenta revolução de 1893, caía pela metade e a pobreza aumentava sensivelmente entre a população fronteiriça.

É, mais precisamente, a partir de 1870 que a diferença de classes se impõe com o cercamento definitivo dos campos, fazendo desaparecer quase por completo o gaúcho "changador" (preador de gado xucro ou chimarrão), "rebelde a qualquer lei, indiferente à propriedade privada, infenso à vida gregária, vagabundo de todos os caminhos". Nesse contexto, muitos não proprietários "tornam-se agregados, utilizando pastagem alheia com pagamento em forma de prestação de serviços ao proprietário, e a valorização das terras leva ao surgimento do sistema de arrendamento. A maior parte da população, contudo, começa a formar pequenos povoados e "rancharias", geralmente congregando os que foram excluídos da nova ordem com a redução da força de trabalho necessária a partir do cercamento dos campos."

Por outro lado, a classe vinculada ao mundo pastoril, apesar de sua permanência direta ou indireta no domínio político do Rio Grande do Sul até a década de 1930, já teria perdido, no início do século XX, sua posição na liderança econômica no Estado, embora os valores que provinham dessa classe, como a suposta harmonia entre proprietários de terras e agregados, a vitalidade da vida do campo, a figura "emblemática e identitária do gaúcho", reinassem na historiografia e na literatura, com a finalidade, entre outras, de "expurgar do horizonte regional os conflitos sociais, reduzindo os níveis de tensão às disputas externas, dos "outros" contra o Rio Grande" e de projetar a figura de Getúlio Vargas ao poder nacional.

Getúlio, todavia, ao assumir o governo federal, centraliza o poder, especialmente com o Estado Novo, o que traz a derrocada política dos chefes regionais do Rio Grande do Sul. Também assume um modelo de desenvolvimento capitalista voltado para a 
"acumulação através do capital industrial, deixando em posição secundária e subordinada à economia agrária".

Em síntese, há derrocada de um mundo e dos senhores da terra, impotentes diante do processo de desenvolvimento, de internacionalização do capitalista em curso e há a tragédia particular dos deserdados de um e outro sistema, tão bem representada nas narrativas de Cyro Martins, que desenha "o drama daquele proletário dos pampas progressivamente expulso do latifúndio pecuarista. Batido pelo cercamento do campo e pela concentração cada vez maior da propriedade da terra, esse homem do campo se vê despojado não só da propriedade ou do direito de nela morar como daquilo que a literatura gauchesca celebra em prosa e em verso: o cavalo. A pé, seu destino é a periferia dos acanhados centros urbanos da região da Campanha ou o rumo da capital, indo proletarizar-se nos bairros miseráveis em torno de Porto Alegre."

Cyro Martins participa do chamado regionalismo modernista que se desenvolve a partir de 30, "já que retoma e aprofunda, atualizando, a chamada tradição regionalista do Sul", "substituindo a romântica perspectiva do conjunto da história, do lendário dos costumes e da paisagem, pelo enfoque realista, no sentido do aproveitamento crítico, com finalidade criadora, das próprias vivências e da dramática social." A literatura de Cyro Martins aproxima-se à gauchesca de Hernández por ser de cunho social.

O tipo humano que pereniza não é a figura do "gaúcho-herói", mas a do "gaúcho a pé, personagem sem eira nem beira , simbolizado em Chiru (Sem rumo), João Guedes (Porteira fechada) e Janguta (Estrada Nova)". Assim, fica claro, por meio da voz de um narrador onisciente, "a distância que havia entre a idealização da vida pastoril e a realidade do gaúcho miserável”, tão bem retratado por esse escritor rio-grandense

\section{5- Erico Verissimo}

Ao analisar a literatura regionalista do Sul do Brasil dos anos 1945, ressalta-se a

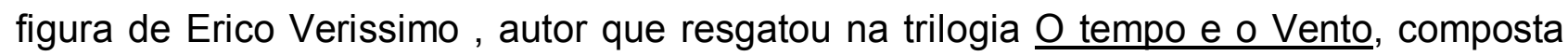

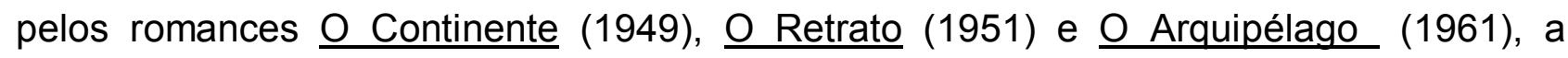
História do Rio Grande do Sul e de sua gente.

Da mesma forma que Cyro Martins, Erico, como afirma Gilda Neves da Silva Bittencourt, sempre se mostrou avesso ao regionalismo tal como praticado na literatura 
gaúcha do início do século, sobretudo ao culto do heroísmo, das ações guerreiras e da violência." Assim, o autor procura, na trilogia O Tempo e o Vento, recontar a História do Rio Grande do Sul, de 1745 até 1945, por meio das vidas dos Terra-Cambará e, mais

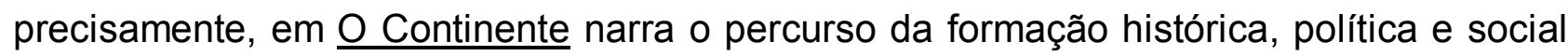
do Rio Grande do Sul, colocando em xeque muitas das concepções históricas vigentes nos anos 40 .

Começa a escrever essa trilogia, num contexto histórico marcado pelo Estado-Novo, cujo "projeto político-cultural procurava evidenciar o valor do "povo" por suas tradições, usos e costumes, e também ressaltar a existência e a importância de "personagens históricos" que "resumiam" em si mesmos as qualidades desse "coletivo e, em o fazendo, asseguravam tanto a continuidade quanto às transformações de nossa sociedade. "Intérprete da vida brasileira", o Estado-Novo propunha-se a formar uma galeria de "heróis" em sentido bem amplo: representantes dos princípios formadores do povo brasileiro, que podiam exprimir seus sentimento, necessidades e aspirações. Eram os homens que traduziam "o que há de melhor e mais expressivo para a avaliação do espírito brasileiro, em sua tarefa construtora", inclusive porque definia-se o "valor de um povo pelo valor de suas elites (...) artistas de todos os gêneros, estadistas, cientistas , figuras ilustres da vida pública".

Dessa forma, Erico, assim como Cyro Martins, "escreve num momento que se encontra em processo de "universalização", para a sociedade gaúcha como um todo, uma determinada visão da História do Rio Grande. Construção ideologizada, tal postura afirmava que o Rio Grande sempre fora o "paladino da liberdade", seu povo lutara sempre por causas justas e possuía virtudes inatas, representadas na figura de seu personagem-símbolo , o gaúcho: destemor, altivez, bravura. Tal visão idealizada completava-se na idéia de que, na sociedade sulina, não tinha havido hierarquias ou distinções sociais. Teria vigorado uma verdadeira democracia dos pampas na qual peões e estancieiros trabalhavam lado a lado, irmanados ambos pela identificação na mesma figura mítica do gaúcho."

Erico procura, por meio de um discurso ficcional, que difere, portanto, do historiográfico, uma nova forma de contar a história do Rio Grande do Sul, embora, em seu romance, alguns aspectos, como datas, costumes, coincidam com as obras historiográficas da época no que diz respeito à matéria informativa. O próprio autor, em 
suas memórias, esclarece que "a verdade sobre o passado do Rio Grande devia ser mais viva e bela que a sua mitologia. E quanto mais examinava a nossa História, mais convencido ficava da necessidade de desmitificá-la."

O "modelo de história comum dos fatos", sem homens reais, sem idéias, em que além da narração dos acontecimentos nada resta a averiguar é contestado por Erico. Tal

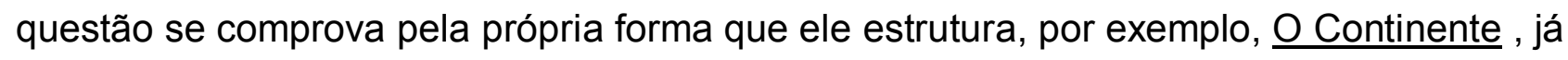
que a quebra do tempo da ação de "O Sobrado" para trazer outros episódios, mostra que o autor é contra esse "método cronológico" e o que vai importar é colocar "em pé", dar vida às figuras negligenciadas pela História, mas que muito fizeram para construir o Rio Grande do Sul.

É visível, dessa forma, o tributo que Erico presta à mulher, visto que no plano da historiografia ela foi varrida, "tanto enquanto protagonista quanto em termos de ofício de historiador. Na sociedade patriarcal forjada historicamente na guerra, no trato do gado e do contrabando, nenhum papel de destaque lhe era reservado e eram as chamadas virtudes masculinas as mais celebradas: força, coragem e destreza. Na obra de Erico, as figuras femininas são os "personagens-terra", os elementos que puxam para a realidade. Personagens fortes, racionais, estáveis, contrastam com as figuras masculinas que são todas de ímpeto e emoção, imprevisíveis, arrebatadas , apaixonadas" .

São as mulheres que, na maioria, questionam o porquê de tanta guerra e comentam a sua inanidade. São também os soldados, simples soldados, como Florêncio Terra, que mostram os ferimentos não só físicos, mas espirituais das revoluções, tão esquecidos pelos manuais de História.

Erico Verissimo também atribui , assim, voz àqueles que pouco ou nada são mencionados nas obras historiográficas. Na voz de Fandango, por exemplo, com seus "causos", o autor evidencia que quem faz, narra e prende a História é o homem, o homem vivo. A História deveria, assim, ser narrada com todos os seus pronunciamentos, e não somente pelo filtro daqueles que pertencem a uma elite intelectual afastada do cotidiano dos que também vivem e sentem as conseqüências do entrelaçar dos acontecimentos políticos, econômicos e sociais.

Atribui-se imensa coragem a esse escritor, que pôs em xeque certas assertivas da escrita da História presentes no momento em que escrevia, inovando o regionalismo, ao trabalhar os conteúdos culturais regionais com soluções artísticas renovadoras, sem serem contraditórias com a herança que devem transmitir. 
Nesse sentido, uma das marcas das tendências de vanguarda na trilogia $\underline{\mathrm{O} \text { Tempo }}$

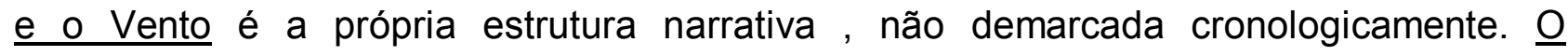
Continente, por exemplo, encarado sob o ponto de vista da trama, isto é, da ordem em que os fatos aparecem no livro, principia pelo episódio "O Sobrado", chamado de episódio-eixo, que ocorre temporalmente mais próximo do presente, porque entre cada dois de seus capítulos se interpola um dos episódios anteriores, chamados de episódios periféricos, de modo que a sucessão do livro é a seguinte: "O Sobrado I", "A Fonte", "O Sobrado II", "Ana Terra", "O Sobrado III", "Um Certo Capitão Rodrigo", "O Sobrado IV", "A Teiniaguá", "O Sobrado V", "A Guerra", "O Sobrado VI", "Ismália Caré" , "O Sobrado VII". Esses episódios periféricos (“A Fonte”, "Ana Terra”, "Um Certo Capitão Rodrigo, "A Teiniaguá", "A Guerra" e "Ismália Caré") estão dispostos em ordem cronológica, de maneira que vão se aproximando cada vez mais do episódio-eixo. Assim, a narrativa é constituída pela alternância entre uma época mais próxima e épocas mais distantes, ou seja, por uma parte do episódio-eixo passada mais próxima do presente, e um episódio-periférico mais distante no tempo. Portanto, "O Sobrado" constitui o presente narrativo (1895) do livro inteiro, pois nele se enquadram a época e a situação que primeiro são apresentadas ao leitor e em face das quais os demais episódios são recapitulações ou passado.

É evidente que essa quebra do tempo da ação de "O Sobrado" para trazer outros episódios acontece porque o autor é contra o "método cronológico" da historiografia que se esquece da "psicologia e da história" dos indivíduos; é contrário ao modelo de história comum dos fatos, sem homens reais, sem idéias, em que além da narração dos acontecimentos nada resta a averiguar. Para Erico o que importa é colocar "em pé", dar vida às figuras negligenciadas pela História, como acontece nas obras de Cyro Martins. Essa é uma das explicações atribuídas a essa quebra do tempo no romance $\underline{0}$ Continente. Contudo, é claro que essa contribuição técnica de inigualável composição artística delineia um traço da modernidade.

Dentro desse panorama, quando se fala em Regionalismo, a partir das obras de um Simões Lopes Neto, ou de um Cyro Martins ou de um Erico Verissimo, nota-se que essa nomenclatura perde a conotação de estar ligada a uma literatura a serviço da classe dominante e ganha uma visão positiva, embora ainda permaneça nos livros desses dois últimos muito da forma da prosa regionalista dos primeiros tempos, como o 
narrador em $3^{a}$ pessoa, apesar de esse não ter o tom de erudição dos primeiros regionalistas. Quando dizemos que Lopes Neto, Cyro e Erico são regionalistas, queremos falar que narram, sim, a História de uma região específica, mas além de demonstrarem os dramas específicos daquele território, também tocam, por meio do viés lingüístico elaborado, tão caro à grande literatura, o nervo da vida, o que traz a universalidade a seus romances, já que sua literatura fala ao homem de qualquer parte, não apenas ao do Rio Grande do Sul.

Partindo dessa assertiva e supondo como obra de maior destaque da gauchesca o Martín Fierro, de Hernández, fica claro porque Chiappini, quando fala na gauchesca presente no Brasil no terreno da prosa, cita Simões Lopes Neto, Cyro Martins e Erico Verissimo. São escritores cujas obras, como a de Hernández, falam do gaúcho, mas num tom que o humaniza, não que o sacraliza simplesmente num altar mítico; são escritores que usam o verbo do presente, ou seja, apesar de narrarem, muitas vezes, o passado, estão atentos aos entreveros de seu tempo; são autores que mostram o gaúcho, mas fazem com que ele dialogue com todas as nacionalidades e etnias para fazer ecoar suas misérias sociais e de ser humano frente a um mundo que está em constante transformação; são escritores gauchescos, regionalistas (num sentido amplo), brasileiros e universais.

\section{6- O contexto das obras de Faraco}

Ao verificar essa análise rápida das obras dos regionalistas da década de 1920, da obra e do projeto literário de Simões Lopes, de Cyro Martins e de Erico Verissimo, verifica-se que tanto a forma como o conteúdo dos contos de Sergio Faraco parecem ser uma espécie de simbiose, ou melhor, uma continuidade de muitas tendências anteriores a ele.

Mas, inegavelmente, o contexto em que Faraco escreve suas obras difere dos demais. Ele publica seu primeiro livro de contos, Idolatria, em 1970, mas nele, como mencionado anteriormente, não havia nenhum conto "fronteiriço". Apenas, no seu segundo livro, Depois da Primeira Morte, em 1974, surgiu “Travessia”, num contexto onde o processo do capitalismo industrial, que, nos países desenvolvidos, teve seu ápice nas décadas posteriores à Segunda Guerra Mundial, chegou à plenitude nos países da América Latina, embora ainda hoje não se tenha esgotado. 
O início desse processo que desloca a produção econômica do campo para a fábrica nos pólos urbanos já está deflagrado, como observado, nas obras de Cyro Martins. E o homem que migra da zona rural para a urbana, expulso de um contexto onde a terra era a base da economia, não vai conseguir se integrar ao sistema industrial baseado numa forma específica de trabalho, como a exploração da mais valia, baseada no capital, nas energias exauríveis, na produção de matérias-primas. Esse homem não pertence mais a um mundo rural em decadência, no entanto não consegue se adaptar ao novo. Assim, quando o velho não possibilita lugar ao novo, o caos torna-se eminente.

Essa sociedade industrial constrói-se sob códigos bem determinados, como a padronização e massificação das informações, dos comportamentos e dos horários. Porém, como Tofler afirma, esse tipo de sociedade começa a se dilatar para desembocar no que chamamos modernamente de globalização:

"Com tecnologias baseadas no vapor e no carvão de pedra, e, mais tarde, com o advento da eletricidade, tornou-se possível para um fabricante de tecidos de Frankfurt, de relógios em Genebra, ou de têxteis de Manchester produzir muito mais unidades do que o mercado local podia absorver. A nova tecnologia também precisava de matérias-primas de longe. O operário de fábrica também era afetado por eventos financeiros que ocorriam a milhares de quilômetros de distância: os empregos dependiam de mercados distantes.

Pouco a pouco, conseqüentemente, expandiram-se os horizontes psicológicos. Os novos veículos de comunicação aumentaram a quantidade de informação e atrativos de terras distantes. Sob o impacto destas mudanças desvaneceu-se o localismo. Agitou-se a consciência nacional."

Na visão de Tofler, o trabalho mecânico, massificado nas linhas de montagem irá ceder lugar à globalização, vista por esse autor "como um processo recente, fruto da Terceira Onda ou da Terceira Revolução Industrial, tecno-eletrônica, fundada no livre mercado (denominado por muitos de neoliberal), na livre circulação de bens, capital, e serviços na sociedade informacional, pós-industrial. Com isso haveria uma ampliação dos princípios de liberdade democrática, a afirmação de regimes multipartidários, juntamente com uma economia sem fronteiras com a superação do espaço pelo tempo."

No entanto, já numa postura mais crítica, sabemos que a globalização é inerente ao capitalismo; é construída gradativamente desde as origens desse sistema. Se pensarmos em mercado como uma relação de trocas dentro de um terrritório denominado 
Estado-nação, ou trocas que ultrapassam esse limite, principalmente feitas por meio do dinheiro, num modelo baseado no lucro, podemos afirmar que a globalização, desde o final do século XVII, quando explode a Revolução Industrial na Europa, já se faz sentir. Porém a maioria dos autores diferencia a fase de internacionalização do capitalismo, quando o estado-nação e a produção em série, fordista, tem um papel fundamental, e a fase da globalização, dominada pelo capital financeiro e pela maior flexibilidade da produção, sentida, no Brasil, a partir dos anos 1990.

A internacionalização do capital acopla a produção do trabalho fragmentado às linhas de montagem das fábricas. Essa lógica chega ao ápice, no Brasil, durante o período da ditadura militar que, de fato, a partir da década de 70, permitiu que diversas empresas multinacionais transferissem suas linhas de montagem para o Brasil, que contava com grandes depósitos de matéria-prima (ferro), uma indústria de base capaz de transformar essa matéria prima (siderúrgicas) e mão-de-obra abundante e barata.

Assim, era muito mais lucrativo para essas empresas produzirem, por exemplo, automóveis no Brasil e venderem para seus países de origem. Mesmo porque a equipe econômica do governo trabalhava no sentido de manter baixos os salários (portanto, os custos de produção). Qualquer reivindicação trabalhista por melhores salários era reprimida com violência. Desse modo, nos anos 70 , o modelo econômico brasileiro estava intimamente ligado ao modelo político, ou, mais ainda, pedia uma estrutura política autoritária.

No entanto, é também a partir dos anos 70 , que gritos de resistências contra um poder de homogeneização que transcende o nacional e começa a firmar o domínio do capital financeiro começam a ecoar nas diferentes regiões do Brasil, entre elas no Rio Grande do Sul. São gritos de resistências contra o que modernamente chamamos globalização "que deixa à margem uma imensa periferia e provoca com isso uma desigualdade social inédita na história. A mercantilização da vida humana nunca teria atingido níveis tão amplos (onde quase tudo é passível de compra e venda) e com ela a difusão de (des)valores consumistas e individualistas."

Sintoma de que surge no Sul do Brasil a necessidade de lutar contra essa "homogeneização da vida", contra "o achatamento das diferenças", que começa a se fazer presente, é a retomada da raiz "terrunha" com o "Festival da Califórnia da Canção Nativa" criado na cidade fronteiriça de Uruguaiana no ano de 1971. A revista "Fronteira Livre" de setembro de 2005 traz uma reportagem que demonstra bem a necessidade da 
população fronteiriça de retomar o universo agropastoril que moldou a identidade cultural e regional do Rio Grande do Sul, desde tempos remotos como já abordado:

"Relegada à área rural dos municípios de vocação agropastoril, com poucos admiradores na área urbana e raríssimos na capital do Estado, a música e a poesia crioula eram escassamente divulgadas.

(...)

O festival uruguaianense ofereceu um palco permanente para velhos e novos talentos do nativismo e desde sua primeira edição contou com alguma cobertura da chamada grande imprensa. Do convívio destes veteranos e estreantes, alguns com formação nitidamente urbana, surgiu a nova música do Rio Grande do Sul, com letras mais elaboradas e músicas mais cosmopolitas, sem perder a raiz terrunha."

Nesse artigo, é constatado ainda que "o nativismo ultrapassou a música, passando a influenciar no comportamento de grande parte da juventude, incluindo a da capital do Estado. Hábitos pouco difundidos nas grandes cidades do Rio Grande do Sul, como Porto Alegre e outras com grande contingente de imigrantes italianos e alemães, antes existentes apenas nas regiões pastoris, passaram a fazer parte do cotidiano de milhares de jovens, como tomar mate, usar alpargatas, boinas vascas e ouvir música nativista. Bares onde as comidas e músicas típicas de nossa região eram consumidas, tornaram-se febre."

Esse apego a aspectos característicos de uma região para demonstrar suas peculiaridades esbarra na ideologia da classe dominante. Do mesmo modo que a construção do gaúcho-herói, com todo o universo que o cercava, foi forjada para alcançar certos ideais dos estancieiros, não estaria o reavivar desse apelo ao mundo gaúcho, agropastoril, a partir dos anos 70, também envolto novamente por uma ideologia? Além disso, não é questionável retomar uma cultura pertencente à classe que tanto poder político e econômico exerceu sobre o Rio Grande do Sul e que detém até hoje vastas porções de território, fator tão questionado dentro de uma sociedade democrática cujo objetivo é garantir função social à terra?

Surge, então, a possibilidade de os "novos" donos do poder usarem da ideologia, que um dia sustentou a hegemonia político-econômica dos grandes proprietários de terra, para transformarem o latifúndio decadente em um espaço simbólico, fonte de identidade e "orgulho" para todos os gaúchos, e para assim nublarem o questionamento sobre as reais condições de vida. Contudo, esse processo pode gerar, dialeticamente, o seu 
reverso, já que surgem mobilizações, como, por exemplo, o movimento dos Sem Terra, cuja essência é garantir uma efetiva reforma agrária nos vastos espaços improdutivos. A resistência desses grupos "pode ser um sintoma de que a construção de uma verdadeira identidade regional não pode permanecer apenas no âmbito ideológico, exigindo, para continuar a existir, um mínimo de materialização dessa igualdade que ela diz representar."

Se os poderes homogeneizadores do capistalismo industrial e do capital financieiro internacional, a partir dos anos 70 , começam a fazer uso dessa identidade regional para poder se firmar, outros grupos, excluídos desse sistema, caso articulados, também podem fazer uso dessa identidade para "reivindicar o seu lugar, ou pelo menos, um lugar menos segregado dentro da sociedade regional."

Os contos fronteiriços de Faraco demonstram que o homem que vive na fronteira parece intuir a necessidade de resistência frente a um processo que o engole. No entanto, a necessidade de lutar pela sobrevivência, pelo "seu ganha pão" apaga a possibilidade de reivindicação de seu lugar. Mas se as personagens não conhecem essa necessidade, Faraco, ao evidenciar a realidade desse homem, busca "salvá-lo" ao dar voz a eles, por meio da literatura.

\section{7- Os contos fronteiriços}

\section{1- "Lá no Campo" e "Aventura na sombra"}

Embora "Lá no Campo" tenha sido publicado pela primeira vez no livro $\underline{\text { Noite de }}$ Matar um homem (1986), e outros contos com a temática fronteiriça tenham nascido antes dele, a primeira parte dos Contos Completos é aberta por essa narrativa.

Uma das justificativas para isso é sua ação se localizar mais distante no tempo do que a dos outros contos. Além disso, "Lá no campo" retoma, em alguns aspectos, os modelos tradicionais da prosa regionalista.

O início do conto é marcado pelo descritivismo do espaço para colocar em relevo os dois ginetes, o velho Cuertino López e seu filho Joca, cujo andar é comparado ao trote manso, ao trote repousado dos animais do campo. Mais adiante, há uma descrição ampla do espaço da estância para onde se dirigiam, que constitui uma "pequena mancha" descritiva, já que a ação é paralisada para dar ênfase ao espaço privilegiado da vida rural: 
"Era noite fechada quando chegaram à sede da fazenda cujos campos tinham acabado de cruzar. Aproximaram-se da casa pela frente, a cuscarada acoando ao redor. As paredes chatas branquejavam entre as árvores, eles viam a varanda em arco e ao lado o traço esguio do catavento, como um louva-a-deus em pé. A regular distância o galpão, a grande porta iluminada, atrás do galpão uma meiágua a dessorar suas indecisas luzes. Num sítio baixo, descampado, começavam as mangueiras, os banheiros do gado, e subia de lá um cheiro embrulhado de bosta e remédio.

No palanque havia dois cavalos. Maneados e dispersos, mais quatro, e os seis traziam garras domingueiras. $O$ velho e seu filho detiveram-se ali, mas não desmontaram. Das casas já vinha um homem."

Além desse descritivismo do ambiente campeiro, a ação das personagens fica em segundo plano, para ressaltar certos costumes, como tomar chimarrão. O narrador em $3^{a}$ pessoa oferece pormenores desse ato, dizendo que o capataz, na sua vez de tomar, enchia a caneca e "a volta recomeçava, sempre pelo lado esquerdo".

Há também detalhes da comida e do procedimento natural da peonada quando acabava a "bóia"; assim "ao final da refeição fizeram questão de atestar, com discretos arrotos, que a canjica com charque estava ao contento"

O Doutor Romualdo, dono da estância, é colocado brevemente em cena, descrito como "homem maduro, mas robusto, de rosto aberto, franco, um vulto às antigas". Após conversarem com esse estancieiro, Vicente, o capataz da estância, e Cuertino concordam que ele é um homem bom, num contexto onde peões e patrões entendem-se, porém fica bem demarcada a hierarquia entre eles.

O narrador, embora em $3^{a}$ pessoa, em muitos momentos, compartilha da fala dos peões, evidenciando que não existe um foco narrativo plenamente distanciado, já que a ruptura entre narrador e personagem não se faz sentir tanto, uma vez que, em muitos momentos da narração, há a utilização de palavras específicas empregadas na Campanha. O narrador, dessa forma, diz que "o Doutor Romualdo mandava saudar os visitantes e os invitava para um copito de licor."

Além disso, o narrador demonstra uma psicologia machista, que o aproxima da dos peões das estâncias. Como "uma chinoca petiça e ligeira, desprovida de beleza mas não de carnes", descreve a peona que serve canjica àqueles que estão no velório do sogro de Vicente, acontecimento que havia trazido o velho Cuertino e seu filho Joca à estância. 
E como não podia deixar de ser, Vicente é um excelente contador de causos. Mas quando ia desfiar um deles dizendo que "em mil e novecentos e...", é interrompido por Cuertino que o repreende por desejar "desencatarrar a memória", o que demonstra que não interessa a marcação definitiva do tempo, embora nesse conto fique evidente que as cercas predominam e o gado é marcado, para não se confundir com o do vizinho, caso "saltem para outro campo".

Embora haja destaque aos costumes, para evidenciar que, por exemplo, começar um "bom velório" com uma roda de truco não são tão coisas de velhos assim, a ação do conto está distanciada, mesmo porque o título é "lá no campo", e não "aqui no campo". Essa narrativa constitui, então, simples "recuerdos de gente velha", como afirma Cuertino, mas, certamente, esses recuerdos têm contagiado os mais novos.

E uma história desses "mais novos" aparece em "Aventura na sombra". Apesar de esse conto surgir em 1984, no livro Manilha de espadas, é o segundo da primeira parte dos Contos Completos.

Como "Lá no Campo", a descrição da paisagem rural abre "Aventura na sombra", e o tempo também não é demarcado com precisão, pois o interesse central é mostrar a aventura de um guri que faz de sua égua, Flor-de-lis, sua primeira "fêmea".

Com a desculpa de ir até o Bororé, o povoado mais próximo da estância onde reside, o menino pára no meio do caminho e "com gestos rápidos, nervosos, maneia a égua e a empurra de ré contra o alambrado. Sobe no terceiro fio e se deita sobre suas ancas."

O narrador em $3^{a}$ pessoa é onisciente e conhece muito bem o universo daquele guri do campo e suas intenções, pois descreve de forma erotizada a paisagem, que se mistura às apreensões do menino:

"De uma cacimba rasa, quase sumida entre inhames e samambaias, ai-que-susto, o rufar das asas de um pombão. Perto, pertinho, a sanga se esfregava em pedras redondas e nas duras raízes do arvoredo."

Esse conto traz os sustos do menino que se faz homem num ambiente de estância.

\section{2- "Dois Guaxos"}

Esses sustos da meninice e o sentimento de que alguma coisa está mudando no tocante ao universo infantil também estão presentes em "Dois guaxos", publicado pela 
primeira vez, em 1984, em Manilha de espadas. Em Contos Completos é a terceira narrativa da primeira parte.

Entretanto os sustos das descobertas cedem lugar aos sustos do desamparo. $\mathrm{O}$ espaço rural privilegiado dá lugar à miséria de um menino, Maninho, que presencia sua irmã, Aninha, de dezessete anos, entregar-se ao Cacho, um índio velho que viera do Bororé "para ajudar na lida e era dia e noite mamando num gargalo e ensebando o baralho espanhol".

Sua irmã, depois da morte da mãe, era quem cozinhava, remendava o "trapeiro" e ensinava-lhe a ler umas poucas palavrinhas. Mas, Maninho, amargurado, pressentia que ela "ia virar puta de rancho, puta de bolicho e no fim uma daquelas reiúnas que vira algumas vezes na carreteira, abanando em desespero para caminhão de gado."

Já que o "velho gambá" de seu pai não se dava conta da miséria física e psicológica que ameaçava os filhos, o menino resolve partir daquela "chacrinha", pois sentia "quanta falta de alguma coisa que não sabia o que era e já se perguntava, afinal, se não era o tal de amor."

É esse desamparo que o leva a montar no seu cavalo e se atirar no mundo. Resolvera que iria para Itaqui. "Depois ia cruzar o Rio Uruguai, ou não cruzar, ou ia para Uruguaiana, Alegrete, ou para a Barra, Bella Union, lugares dos quais ouvira um dia alguém falar." E, um dia, quem sabe voltar "para subir o cerrito de pedra nos fundos do campinho, para atirar uma flor na cruz da velha morta, de quem, agora mais do que nunca, sentia tanta saudade."

Esse conto surge no livro Contos Completos como uma espécie de fronteira que divide o universo campeiro dos mais privilegiados daquele dos menos favorecidos; demarca o desaparecimento de um mundo harmônico, onde havia mais liberdade e os valores tradicionais eram cultivados. Nesse contexto, os personagens, como Maninho, até podem fugir a cavalo, mas ficarão a pé, engrossando os vastos cinturões da miséria das cidades de fronteira.

Essa sensação de desamparo também acomete muitos dos personagens de Arregui. Reyles, protagonista do conto "Noche de San Juan" também sente essa solidão, esse desamparo frente ao seu mundo de miséria. Assim como Maninho, Reyles não consegue identificar a causa de tanta angústia.

\section{3 - "Manilha de espadas"}


Indubitavelmente, a miséria não possui "nenhuma cerca divisória", como atesta o narrador em $3^{a}$ pessoa do conto "Manilha de espadas", cuja descrição inicial não aborda a riqueza da paisagem rural, como as três narrativas anteriores, mas denuncia a pobreza do vilarejo:

\begin{abstract}
"Na rua principal daquele povo havia uma barbearia, um bolicho de miudezas, uma ferraria e a pensão de Pepeu Gonzaga, além de umas poucas casas com quintais profundos e nenhuma cerca divisória. Numa delas funcionava a igreja, noutra o posto de saúde, que só abria às terças, quando vinha plantonear a enfermeira de Itaqui."
\end{abstract}

"Manilha de espadas" foi publicado pela primeira vez, em 1984, no livro que recebe o mesmo nome desse conto. Nos Contos Completos surge como a quinta narrativa da primeira parte e evidencia o cotidiano dos pequenos povoados próximos às cidades da fronteira.

O narrador, como nos contos anteriores, adota o falar local, embora não participe diretamente dos acontecimentos . Entretanto, em muitos momentos, ele se intromete na narração para estabelecer sua opinião:

"No envido e no real-envido, na flor e na contra-flor, no truco, retruco e no vale-quatro, assim como nas senhas ou morisquetas que correspondem ao valor das cartas e, principalmente, na charla tramposa dos jogadores, o truco é um jogo que desnuda o homem do avesso."

Outro exemplo dessa intromissão surge mais adiante:

Era um trato antigo. Arribava um visitante à pensão, Pepeu avisava os outros e, de combinação, desbuchavam o infeliz. Às vezes as pessoas eram alertadas, mas se achegavam para orelhar o jogo e quase nunca resistiam. Que outro passatempo encontrariam os homens naquele rincão olvidado pelo mundo?"

Por meio dessa técnica, há a nítida impressão que esse narrador conhece bem aquela realidade e está a contar um "caso" do qual até pode ter participado, mas que não quer revelar, pois esta é a história de um assassinato. 
O forasteiro, que viera parar naquele vilarejo perto da fronteira e se hospedara na pensão de Pepeu Gonzaga, é convidado a jogar truco; porém é roubado pelo dono da pensão e pelos seus comparsas, Comissário Boaventura e o mulato Isidoro, cabo da Brigada e chefe do destacamento local. Assim, quando o jogo acaba e todos se recolhem para dormir, o forasteiro mata o dono da pensão e foge com o dinheiro.

Embora fosse questionada a origem desse forasteiro, ela permanece misteriosa, apesar de o comissário desconfiar de que seja "daquela arraia miúda que vai a Uruguaiana pra chibar na ponte internacional."

O que chama a atenção é a descrição daquele sujeito estranho ao local: "era um homem de porte amediado, mui recheado de pulso e mãos calosas, descascadas pela agrura de algum serviço ingrato. Trazia a barba por fazer, a cabeça enterrada num boné branco e melenas como pouco se viam naquele pago, longas de espanar os ombros e suja e bem embaraçadas. Calçava alpargatas velhas, e os demais de sua indumentária podia divertir ou inquietar: uma calça puída de um incrível veludo e uma antiga túnica militar, cuja gola se mantinha erguida nas laterais do queixo."

A palavra "incrível", nessa descrição, soa muito forte, pois remete ao inacreditável, ao extraordinário, a uma distância no tempo confirmada pelo adjetivo "antiga" que qualifica a túnica militar usada pelo forasteiro, o que pode remeter ao "incrível" Rodrigo Cambará, personagem de Erico Verissimo.

Também, ao chegar ao povoado de Santa Fé, o Capitão Rodrigo Cambará vestia uma túnica militar. Apesar da diferença notória entre Rodrigo Cambará, que não apresenta a cabeça enterrada num boné, mas possui um "chapéu de barbicacho puxado para a nuca, a bela cabeça de macho erguida, e aquele olhar de gavião", e o forasteiro, ambos possuem nas vestes o qualificativo militar que moldou a identidade do gaúcho como o "entalhador de fronteiras". E, embora o forasteiro seja um Rodrigo às avessas, dada sua maior "ninguendade" (nem o nome dele saberemos) e sua pobreza, os resquícios que o qualificam como guerreiro perduram, uma vez que a gola de sua túnica permanecia erguida como sintoma de sua altivez.

Mas o forasteiro não se comporta com o heroísmo destemido do lendário Cambará, ao contrário, depois de se ver enganado no jogo de truco, espera o dono da pensão dormir e o assassina, para pegar todo o dinheiro.

Porém esse assassinato não é colocado no conto como um imprevisto, uma vez que, logo após o jogo, o forasteiro vai se deitar num quarto onde há um guri (seria o 
menino que fugiu de sua chacrinha no conto anterior?) que o chama de tio. O menino aguarda as ordens do homem, pois também "se deitara sem tirar as alpargatas. Decerto revivendo outras madrugadas de um mesmo ritual." Assim, espera o "tio" "pegar o dinheiro" e rumam para "a fronteira, para o rio, caminhada de uma hora quando muito."

O conto é arrematado com a seguinte descrição:

"A noite madrugava num silêncio frágil, quebrado de longe em longe por mugidos de algum touro inquieto, relinchos de potros, guinchos de corujas, notícias do mundo agreste e invisível que eles agora teriam de atravessar."

Reminiscências de um mundo pastoril são trazidas para eles, no entanto não são visíveis, sentidas, por isso simplesmente eles atravessam, fazem a travessia para uma nova margem de realidade, muito diferente daquela do universo rural, agreste.

\section{4- "Travessia"}

"Travessia" é o título do quinto conto da primeira parte dos Contos Completos. Dentro da obra de Faraco, essa narrativa é a primeira a abarcar a realidade fronteiriça, já que surgiu pela primeira vez no segundo livro de contos de Faraco, Depois da Primeira $\underline{\text { Morte, em } 1974 \text { e também foi incluída na antologia de Os melhores contos brasileiros de }}$ 1974. É reeditada novamente, em 1978, no livro Hombre.

O título "Travessia" é sugestivo, pois sua definição no dicionário atribui a esse substantivo feminino os seguintes significados: "ato ou efeito de atravessar uma região, um continente, um mar; vento rijo e desfavorável à navegação; ação de atravessar mercadorias"

É exatamente a "travessia de uma região" que marca esse conto. "Região" no sentido metafórico, pois o espaço privilegiado da vida no campo da Campanha vai sair de cena para colocar, sob fortes holofotes, o espaço da miséria, a vida daqueles que vivem do contrabando, do chibo, da "ação de atravessar mercadorias", sob um cenário onde "os ventos desfavoráveis à navegação" é o subdesenvolvimento que joga muitos moradores da periferia das cidades da fronteira no "descaminho".

No entanto a vida de contrabando é vista, por quem o pratica, como um ato "natural", embora os "chibeiros" tenham conhecimento de que é uma prática ilegal, prevista no Código Penal. 
Segundo as leis desse código, criadas em 1940, contrabando e descaminho são práticas diferentes. Adverte Magalhães Noronha que "embora o Código Penal confunda contrabando e descaminho, no Art. 334, constituem estes figuras diversas. Enquanto aquele consigna a importação e a exportação fraudulenta de mercadorias, cuja entrada ou saída do país seja absoluta ou relativamente proibida, o descaminho é o ato fraudulento que se destina a evitar, total ou parcialmente, o pagamento de direitos e impostos previstos pela entrada, saída ou consumo (pagável na alfândega) de mercadorias. Assim, a ação física do contrabando é uma, a do descaminho outra. 0 contrabando atenta, geralmente, contra a higiene, a moral e a segurança pública; o descaminho, contra o erário. Enfim, no contrabando, a própria importação ou exportação, bem como a comercialização do produto, são proibidas, ao passo que no descaminho a mercadoria teria sua entrada ou saída do país permitidas, desde que pago o tributo devido."

A pena, tanto para a prática do contrabando ou do descaminho, segundo o Art. 334 do Código Penal, é de reclusão variando de um a quatros anos.

E tio Joca, personagem principal de "Travessia", sabe do risco de praticar o chibo, pois sai de Itaqui, cidade fronteiriça do Rio Grande do Sul, rumo ao Alvear, vilarejo localizado na outra margem do rio Uruguai já pertencente à Argentina, num dia de muita chuva, o que lhe daria a possibilidade de passar despercebido pela patrulha dos fuzileiros brasileiros, que controlavam o movimento do rio.

O que chama a atenção é o nome do contrabandista: Joca. Certamente esse Joca é o mesmo do conto "Lá no Campo", filho de Cuertino López. Mas o jovem cheio de esperança cede lugar ao contrabandista, que pratica o descaminho, porque deve atravessar de um lado para outro do rio "três ventiladores, uma dúzia de rádios, garrafa, cigarros, vidros de perfume e dezenas de cashemeres", para conquistar seu "ganha pão", afinal era "véspera de natal e uma boa travessia, naquela altura, ia garantir o sustento até janeiro."

A narração, diferentemente das outras, é feita em $1^{a}$ pessoa por um menino, que chama Joca de tio e vai participar de toda a ação. Porém, em algumas passagens, parece que sua voz desaparece e dá lugar a um narrador (seria o menino transformado em homem?) que conhece o caso e seu desfecho, e, por isso, faz um alerta (ao leitor) do que vai acontecer: 
"Mas estava escrito: aquela travessia se complicava."

A complicação, primeiramente, vem das forças da natureza: na travessia de volta, já com todos os produtos na chalana, o Tio Joca, na medida do possível, ia "domando" as ondas do rio Uruguai, cujas águas tinham subido muito, em virtude das chuvas, o que proporcionava uma forte correnteza e redemoinhos, "daqueles que podem engolir uma chalana com seu remador"

Tio Joca consegue superar a força do rio, porém não a força da lei: ao perceber que os fuzileiros do Brasil aproximam-se, "mete a encomenda n'água" e o "tesouro" inteiro mergulha no rio.

Quando os holofotes do barco dos fuzileiros acendem-se para iluminar o do tio Joca, ele afirma que tinha peixes ali, mostrando o cesto de cascudos que trazia justamente para uma situação desse tipo.

É obvio que a autoridade duvida, todavia não pode fazer nada, pois não há prova de contrabando. Porém o fuzileiro passa a mão na cabeça do menino e constata:

"-Tão chico e já praticando, hein? Essa é a vida."

Embora a autoridade do lado brasileiro conheça a realidade do contrabando, serve a um poder acima que provém do "centro" e dita as regras, fator, num contexto abrangente, que já estimulou insurreições, como a Guerra dos Farrapos. Sugere-se, então, um corte vertical, provindo de uma força externa à região, já que quem sempre controlou as zonas de fronteira não são forças estaduais ou regionais, mas sim o poder federal.

É claro que a questão está em manter a ordem ou a legalidade, mas sabemos que o contrabando na região de fronteira no Rio Grande do Sul sempre foi uma problemática presente, já que , no decorrer da História, ora era prática consentida, ora proibida.

Já "Guilhermino César, com senso de investigador, rastreou a história do contrabando no Rio Grande do Sul desde a ocupação oficial do estado no século XVII pelos portugueses, quando o comércio ilícito, que contrariava a orientação monopolista da Coroa espanhola, respondia a necessidade de sobrevivência de particulares e dos núcleos urbanos incipientes. A abordagem que faz, com base em documentos de épocacartas oficiais, documentos legais, tratados, registros, correspondências de particulares - 
deixa entrever seu caráter oscilatório, alertando para a mobilidade política e legislativa que fazia do contrabando atividade tolerada, quando não estimulada por governos preocupados em ampliar as fronteiras geográficas de suas colônias e depois das nações americanas recém emancipadas.

Assim, "se na esfera política e oficial o contrabando alterava sua configuração à medida que também outras eram as relações entre nações colonizadoras e colônias, no cotidiano há registros de que o contrabando constituía prática consentida, espécie de comércio peculiar que imaginava-se livre já no século $\mathrm{XIX}$, sendo passível de prática "tudo o que não prejudique o Rei"”.

É também na voz de Blau Nunes, em "Contrabandista", do livro Contos Gauchescos (1912) de João Simões Lopes Neto que tomamos contato com o histórico do contrabando no Rio Grande do Sul. É o próprio Blau que afirma:

"Nesta terra do Rio Grande sempre se contrabandeou, desde em antes da tomada das Missões."

Blau comenta ainda que, naqueles tempos, o contrabando era praticado "sem malícia", e "mais por divertir e acoquinar os guardas do inimigo" Mas, depois da conquista das Missões , o capitão-general dava as sesmarias mas não garantia o pelego dos sesmeiros. Dessa forma, só o "el-rei nosso senhor e só por sua licença é que algum particular graúdo podia ter em casa um polvarim." Também só na vila de Porto Alegre "é que havia baralhos de jogar, que eram feitos só na fábrica do rei nosso senhor, e havia fiscal, sim senhor, das cartas de jogar, e ninguém podia comprar senão dessas!"

Porém, como constata Blau, não era possível "andar com tantas etiquetas e pedindo louvado pra se defender, pra se divertir e pra luxar!". Nesse contexto, os estancieiros iam ou mandavam buscar do outro lado, "nos espanhóis, pólvora e balas, pra pederneiras, cartas de jogo e prendas de ouro pras mulheres e preparos de prata pros arreios... e ninguém pagava dízimo dessas cousas."

Nessa passagem, há referência novamente à arbitrariedade do poder central que não atendia aos interesses dos homens da Campanha, "obrigando-os" à "desordem", cuja "semente grelou e está a árvore ramalhuda, que vancê sabe, do contrabando de hoje."

Como sustenta Léa Masina "ao institucional opõe-se o cotidiano, plasmando-se na literatura o tipo regional e fronteiriço presente na ficção de escritores que concebem a 
personagem não apenas como o que transgride as leis, mas como cidadão que exerce um ofício, sofre perseguições e injustiças, revelando a visão de um cotidiano de sobrevivência. Este assimila o contrabando como forma de comércio supranacional, que requer destreza e ousadia, elementos próximos, num primeiro momento, da figura contrabandista e do gaúcho mitificado pela ficção."

Esses qualificativos de valente e ousado, revelados pelo menino-narrador, compõem a figura de Tio Joca:

\begin{abstract}
"Teso, imóvel, ele olhava para o rio, para a sombra densa do rio, os olhos deles brilhavam na meia-luz da popa e a gente chegava a desconfiar de que ele estava era chorando. Mas não, Tio Joca era um forte. Decerto apenas vigiava, na esteira de borbulhas, o trajeto da chalana vazia."
\end{abstract}

Ousadia, destreza, força, valentia, "hombridade" são atributos que aproximam Tio Joca ao herói- gaúcho mitificado pela literatura dos anos 1920. Mas, como "Diego Alonso" do conto de Arregui, sua heroicidade está em enfrentar uma situação cotidiana.

A figura de Tio Joca é forjada, apesar de ser um "fora da lei", com o peso emocional da voz narrativa do menino que o vê como valente e honrado, atributos que também servem para definir o herói da literatura dos anos 1920, representado pelo gaúcho da zona pecuária, que se confrontam com os do anti-herói , covarde e sem brio, desleal e traidor.

Chiappini ressalta que a figura do contrabandista, o "herói-bandido" que já aparece na literatura das primeiras décadas do século $X X$, também é concebida, apesar de ser degradado pelo meio, como um herói, cuja "pureza e desprendimento contrastam com a maldade e dissimulação do anti-herói." Além disso conclui: "entre os heróis-bandidos, há uns que se encaixam plenamente no paradigma do herói, porque seus atributos são apresentados em equilíbrio. Não se diferenciam em nada de um autêntico Blau dos "velhos tempos". Apenas sua profissão é diferente; em vez de guerreiros ou domadores, ou peões, ou capatazes são bandidos." E este é o caso de Tio Joca, num contexto em que os atributos heróicos permanecem, mesmo diante das forças que o oprimem, que vem de longe de seu universo, da instância federal, que pouco sabe dos seus dramas pessoais, e nada é feito para reverter seu quadro de banditismo. 
A figura de Tio Joca diferencia-se de Rulfo Alves, o chefe dos contrabandistas do conto "Los contrabandistas" de Arregui. Em nenhum momento é construída uma imagem positiva de Rulfo. Já a valentia dos irmãos Correa é relativizada, porque Pedro mata o chefe, apesar da reprovação do seu irmão Juan, para garantir seu "bem-estar", sua sanidade.

Tomachevski, como abordado, esclarece que a construção da heroicidade implica numa íntima relação entre a caracterização e o ponto de vista. A caracterização de Tio Joca é construída pelo olhar do menino-narrador; já Rulfo Alves e os irmãos Correa são caracterizados por um narrador em $3^{\circ}$ pessoa, que tem uma visão de fora do universo narrado, embora não deixe de constatar a arbitrariedade desse mundo fronteiriço e a falta de questionamento dos personagens em relação a ele, pois eles simplesmente "tocam a vida" sem saber o porquê de sua condição marginal.

No entanto, tanto no conto de Mario Arregui, conforme abordado, como no de Sergio Faraco, fica evidente que o contrabando possibilita as trocas inter-culturais numa convivência permanente com o espaço e o outro d'além fronteira, o que possibilita a Pedro Correa, personagem de Arregui, ter um sotaque abrasileirado e considerar um lado e outro da fronteira como uma única região, embora tenha consciência dos limites institucionais.

No conto "Travessia" de Faraco, essa interação é marcada por várias cenas. Quando, por exemplo, Tio Joca chega ao Alvear para pegar as encomendas, seu comparsa nos negócios é André Vicente e sua mulher Dona Zaira, que moram do outro lado do rio, da fronteira. Trecho que evidencia o quanto são próximos é o desejo da mulher de André Vicente de ter o menino-narrador como filho:

"A mulher de André Vicente gostava de me dar confiança porque no tenía hijos. Não era a primeira vez que me convidava para morar com ela no Alvear."

Ao contrário da historiografia de matriz lusitana que, no Brasil, negava as influências entre um e outro lado da fronteira e em oposição a uma literatura das primeiras décadas do século $\mathrm{XX}$, que endossava essa historiografia, Faraco evidencia esses contatos pela relação amistosa, pelo linguajar que mistura o português ao espanhol, e pelos hábitos, comuns a um e a outro lado. A literatura de Faraco é liberta de 
imposições que, no decorrer da História, foram instauradas por reinos e governos. $\mathrm{O}$ contato permanente, a criação de uma identidade cultural compartilhada que aparece na obra de Sergio Faraco já está também abordada no conto "Contrabandista" por Blau Nunes:

"Os paisanos das duas terras brigavam, mas os mercadores sempre se entendiam."

Se as guerras e o contrabando, apesar de serem arbitrários, sempre movimentaram a Campanha e estabeleceram trocas culturais, agora o arbitrário continua na atividade do Contrabando, que, apesar de prática não aceita, continua a sugerir o movimento, a "travessia" de uma cultura a outra; continua a sugerir a mobilidade política e econômica da linha fronteiriça.

Guerra e contrabando são, porém, situações que cortam verticalmente a vida do homem da Campanha e se formulam por circunstâncias adversas à vontade dele. Na verdade, esse homem não percebe a imposição da ilegalidade que o joga à margem do institucionalizado e o empurra ao "descaminho".

\section{5- "Noite de matar um homem"}

Em "Noite de Matar um homem", a sexta narrativa do livro Contos Completos, mas publicado pela primeira vez em 1986 no livro que recebe o mesmo título, o menino-narrador do conto anterior, Travessia", se faz homem e continua a praticar o contrabando.

Embora "a tinta emocional" recaia sobre as ações do próprio narrador, suas atitudes vão contradizer sua heroicidade. Ele se torna ambicioso, já que mata o outro, "vindo de Bagé ou Santiago, ninguém sabia ao certo", porque é um inimigo que atrapalha os negócios do contrabando, o lucro individual num tempo onde "campos e matos da fronteira, por assim dizer, foram mermando, e já não era fácil repartir trabalho".

O alvo do narrador e de seu companheiro, Pacho, é Nassico Feijó, a quem chamavam Mouro:

"Seguido Tio Joca dava com ele no meio de um negócio, e se o ganho era escasso ficava ainda menor. Ele também se prejudicava e por isso se tornou mais façanhudo, mais violento, tão atrevido que em Itaqui apareceu o nome dele no jornal. Era o que faltava para atiçar a lei. (...) 
Ultimamente desviara um barco nosso que subia de Monte Caseros com uma carga de uísque e cigarro americano. Era demais. Tio Joca armou um cu-de-boi e todos estiveram de acordo em que o remédio era um só."

E foi assim que ficou decidido que Pacho e o narrador matariam o Mouro. Depois de caminhar a noite toda por picadas estranhas à caça do inimigo, sentiam-se cansados, "com o corpo dolorido, tropicando como dois pilungos". No entanto, o narrador tem consciência que a ele cabe a valentia, pois havia sido educado na escola da vida onde aprendeu, por meio dos "causos", que "gaúcho de cepa" agüentava sua missão até as últimas conseqüências. Logo, a vontade de lavar a honra deveria ser levada até o fim com a morte do adversário; afinal "não eram esses os causos que se contavam nos balcões, nos batizados, nos velórios?"

Quando, finalmente, encontram o Mouro, a valentia, que tanto prezavam, cede lugar à covardia:

"Senti a mão de Pacho em meu pescoço, no ombro no braço, e quase sem querer começamos a retroceder, a rastejar abrindo caminho com os pés."

No caminho de volta, já pensando na justificativa que dariam ao Tio por não ter completado a missão, já que haviam "se achicado", deparam-se com o Mouro. É, então, no susto, que Pacho atira e derruba o outro que cai morto com os olhos esbugalhados.

O desfecho do conto contradiz a valentia tão propagada a respeito do gaúcho de outros tempos, que via a guerra, a morte dos invasores, muitas vezes, como único remédio, já que Pacho senta-se no chão, abraça a vinchester e chora como uma criança. Enquanto o narrador, frente à cena do assassinato, embora tente encarar condutas de lavar a honra como inevitáveis, vomita e vomita de novo:

"Recuei, não podia desviar os olhos e fui-me afastando e me urinava e me sentia sujo e envelhecido."

A atitude dos jovens contrabandistas do conto de Faraco difere dos irmãos Correa do conto de Arregui. Em nenhum momento, no conto "Los contrabandistas", os personagens recuam ou lamentam sua posição "de fora da lei", apesar de o medo estar 
presente. Já Pacho e o narrador-personagem ficam extremamente abalados por "ter" que matar o homem que os atrapalhava no negócio do contrabando.

Quando voltam para casa, e o Tio pergunta sobre a viagem, o narrador conclui que não adiantava falar, e pensa que não adiantava "choramingar que entre el sueño y la verdad o trem da vida cobrava uma passagem mui salgada".

É com essa declaração que se evidencia que a heroicidade do "entalhador de fronteiras" agora é sonho (e um dia foi real?). Mas o narrador recobra sua altivez, sua valentia e responde ao tio:

"Se tem barco em Monte Caseros, pode mandar subir."

Nessa dinâmica que oscila entre valentia e covardia, os personagens que povoam os contos de Faraco afastam-se do mito. São personagens que sentem na pele a miséria em suas habitações de "um lote de meiáguas cercanas do grande rio", são protagonistas que provocam a simpatia, a compaixão do leitor, quando exibem seu lado frágil. No entanto são personagens que também exibem o lado heróico às avessas, pois são covardes, são assassinos. O objetivo deles, todavia, é a sobrevivência, por meio das próprias leis. E toda essa mistura de caracterizações traz um painel verossímil da vida daqueles "gaúchos" que além de estarem "a pé", provavelmente não têm "recuerdos" de que um dia já possuíram cavalos.

E a reflexão que esse conto proporciona, assim como o conto "Los contrabandistas", segue seu rumo: dentro do institucional, os personagens não passam de bandidos, não passam de anti-heróis forjados num contexto de exclusão embora seu lado mais humano, como a apreensão, o medo, a angústia, seja trazido à tona.

\section{6- "Guapear com frangos"}

Nunca faltar à "palavra empenhada" também é uma atitude que estabelece a heroicidade dos personagens de Faraco que não passam de "tropeiros, chibeiros, pescadores e ladrões de gado daquela fronteira triste".

Fazer valer a palavra também é uma questão de honra para "aquele López" que no conto "Guapear com frangos", o sétimo da primeira parte dos Contos Completos, promete transportar o corpo do tropeiro Guido Sarasua, encontrado já em decomposição 
no rio, uma vez que havia se afogado por se aventurar "à louca travessia" num momento em que a correnteza se sobrepunha às forças humanas.

Quando o narrador apresenta os personagens que resgataram o corpo de Sarasua, ele comenta que nessa atividade figuraram "aquele López e mais certo Honorato pescador e mais um chacreiro e seu filho maior e outros que não vêm ao caso". Nessa última observação fica evidente que há uma voz em $3^{a}$ pessoa que desfia um "caso", como fazia o velho Blau. É a voz de alguém que conhece bem a realidade dos personagens e a linguagem do espaço fronteiriço uma vez que prevalece a mistura do português a expressões do espanhol.

Outra observação é a maneira como essa voz remete ao personagem López. Não diz simplesmente López, mas sim "aquele" López, o que sugere ser a narração de uma façanha do mesmo Tio Joca, cujo sobrenome sabemos ser López, o homem valente e honrado que surge em "Travessia". E essa voz narrativa seria a de seu sobrinho, a do menino do conto "Travessia" que tanto admira o tio e se faz homem no conto "Noite de matar um homem"? Possivelmente.

Interessante ainda notar que se Tio Joca, "em Travessia", luta contra as forças do rio para sua sobrevivência, em "Noite de Matar um Homem", aparece como o mandante de um assassinato. Porém em "Guapear com frangos" novamente atributos positivos marcarão seu caráter; logo suas ações oscilam entre nobres e não nobres, o que lhe confere humanidade, não mitificação.

Ao amarrar o corpo, que já apodrecia, a uma forquilha e ao prendê-lo em seu cavalo, sente que a missão de levar o cadáver até a sua família não será nada fácil, apesar de não aceitar sua fraqueza:

"Nem deixara ainda os sítios inundados quando lhe escapou um gemido. Apeou-se, correu até um pequeno descampado e chegou já vomitando. Sentou-se por ali, arreliado consigo mesmo. Na sua lida diária, de tropeadas secretas que varavam alambrados, de furtivas travessia do grande rio que corria em cima da fronteira, na sua lida de partilhas, miséria, punhaladas e panos ensangüentados, via a morte e a corrupção do corpo como outro mal qualquer, como os estancieiros, a polícia, fuzileiros e fiscais de mato, não podia aceitar que uma viagem de paz viesse a ter enjôos de chininha prenha."

Ao evidenciar a constante luta daquele López como ladrão de gado, contrabandista, assassino, miserável, o narrador evidencia seus inimigos: os 
estancieiros, a polícia, os fuzileiros e os fiscais de mato, num contexto em que o adversário não é mais o outro d'além fronteira, mas sim todos aqueles que, de uma forma ou outra, impedem-no de conseguir o acesso a bens materiais: os estancieiros concentram as terras; os homens da lei o privam de ganhar o necessário pelo contrabando. É uma visão de dentro do mundo daqueles cuja opressão é visível, e embora pratiquem atos ilícitos, repreensíveis dentro de um contexto institucional e humano, soam, pela voz do narrador, como um pedido de ajuda porque se a vida é assim, não significa que deve continuar sendo.

Metáfora de que uma força superior ao homem da fronteira, corrói, devora suas entrenhas, apesar da resistência, é o corpo débil e inerte de Guido Sarasua ser devorado por bichos, durante o cortejo:

"De sua inquietude participava o cavalo, sempre a cabecear, trocar orelhas, de quando em quando um nitrido baixo, ameaçador. Outros taturs? Algum graxaim faminto na retaguarda do cortejo? López sujeitou o cavalo, ouviu o rebuliço de pequenos animais pela ramaria. Desmontou, viu que o Sarasua, depois do papa-defunto ou de outros bichos cujo assédio lhe escapara, trazia uma cova na barriga e parte do costilhar já bem exposta. Outra golfada de vômito e, sentindo que perdia a visão e o equilíbrio, afastou-se com passos trôpegos, foi parar lá longe num montículo de areia onde despontava uma sina-sina."

Toda essa situação de luta daquele López para evitar que o corpo de Sarasua seja devorado remete ao contexto da época em que o conto foi escrito.

Em Contos Completos, "Guapear com frangos" é a sétima narrativa da primeira parte. Porém, foi publicado pela primeira vez Manilhas de Espada (1984), ou seja, numa época em que o Brasil ainda se encontrava sob o Regime Militar, apesar de a abertura estar próxima.

O ano de 1984, no Brasil, é marcado por uma intensa crise, cujas origens estão na própria estrutura do modelo econômico vigente, fortemente dependente do capital externo. A partir de 1979, com a nova crise do petróleo, o país, dependente das importações de combustíveis, vê seu balanço de pagamentos mais uma vez seriamente comprometido. Além disso, depara-se com uma diminuição no fluxo de capital estrangeiro. A brusca elevação dos juros no mercado internacional também ajudou a comprometer a estabilidade da economia brasileira. Finalmente, a inflação que já vinha crescendo desde a época do "milagre" econômico, quando os presidentes-generais 
atraíram empresas estrangeiras para o Brasil, escapou de qualquer controle. Era a estagnação econômica ligada à inflação que ampliava a má distribuição de renda, que não afetava a classe endinheirada, protegida pela correção monetária (se a taxa da inflação era de $20 \%$ ao mês e as aplicações bancárias também rendiam $20 \%$, a inflação para os titulares dessas aplicações era zero.) Assim os mais humildes não tinham como se proteger das elevadas da taxa de inflação, o que tornava evidente a estagnação do corpo social a que pertenciam, devorado por forças que fugiam ao seu controle.

É numa situação de descontrole que se encontra López quando continua a travar resistência contra os enormes corvos (ou seriam contra às oligarquias?) que querem se fartar do resto da carniça de Guido Sarasua.

Naquele esforço, ao ter que lutar contra os corvos e seus inesperados vômitos, López desmaia. E "por menos de hora esteve aquele López como ausente do mundo, mas ao despertar teve a impressão de que se haviam passado dias, semanas, talvez anos."

López ao "acordar" presencia um banquete de aves que "atracavam na carniça" do pobre tropeiro. E, num lance surreal, ele se atraca com um dos corvos, mas não consegue matá-lo. Essa cena traria a imagem de que a redemocratização está próxima, mas os "urubus" continuarão a rondar o poder, pois, apesar de, em meados da década de 80, haver um embrião de uma significativa mudança política, não haveria a ascensão de uma nova classe social ao poder, situação expressa no conto da seguinte forma:

"Era a lei, pensava, e pelear com aqueles frangos negros não ia mudar coisa alguma. E era a mesma lei que reinava em sua vida e na vida de seus conhecidos."

E López conclui que além de aqueles bichos devorarem órgãos vitais, os companheiros do morto devorariam outras "coisas": "uma cadeira, uma bacia, um par de alpargatas poucos usadas, um ficava com a cama, outro com a mulher, e a miuçalha, como a ossada de uma carniça, ia se extraviando ao deus-dará."

Nesse momento, a narrativa rompe o espaço local, nacional para pôr em cena outro poder que consome o homem: os interesses capitalistas, que validam apenas as mercadorias. 
O personagem, então, generaliza esses poderes e conclui: "de que adiantava guapear com os bichos?" Mas o final do conto demonstra a necessidade de resistência frente a tudo isso:

\footnotetext{
"Aproximou-se do corpo estraçalhado. De Guido Sarasua ainda sobravam algumas carnes, protegidas pelas costelas e outros ossos maiores - o bastante para um bando de urubus famintos. Desembainhou o facão:

- Me desculpa, índio velho.

E como quem parte uma acha de lenha, curvou-se sobre o Sarasua e abriu-lhe o osso do peito ao meio."
}

Com esse gesto, López, apesar de perceber a dilaceração do corpo, decide sobre o destino do que resta, o que evidencia a necessidade de obter forças para determinar novos rumos, mesmo diante das adversidades.

\section{7 - "A voz do coração"}

A valentia, a nobreza daquele López do conto anterior contrasta-se com a decadência moral e física dos personagens de "A voz do coração", oitavo conto da primeira parte de $\underline{\text { Contos Completos, }}$ publicado pela primeira vez também em Manilhas de espada (1984).

Em oposição à narrativa anterior que se estabelece por um narrador em $3^{a}$ pessoa, em "A voz do coração" é o narrador-personagem que conta o que aconteceu a ele e a seu amigo Pacho, os mesmos personagens de "Noite de matar um homem". Além deles, também aparece Maidana, novato na matéria do contrabando e do roubo.

Assim as narrativas em Contos Completos alternam-se focando um tempo mais distante e um tempo mais próximo à escrita da narrativa. Quando os valores do gaúcho guerreiro surgem, eles são delatados pela narração em $3^{a}$ pessoa, por meio de uma voz que desfia um caso já um tanto distante no tempo. Já a narração em $1^{\text {a }}$ pessoa é feita por um personagem degradado, que no conto "Noite de matar um homem" ainda sente medo, culpa ao matar um homem que atrapalha os negócios do contrabando; no entanto em "A voz do coração", ele se torna mais frio e evolui na criminalidade, uma vez que além de praticar o "descaminho", torna-se ladrão de estâncias e também tem contato com drogas ilícitas. 
A abertura do conto traz o cenário da fuga do narrador, de Pacho e de Maidana. Eles desejam alcançar o Inhanduí, afluente da margem esquerda do Rio Ibirapuitã, no município de Alegrete, para escapar dos homens de Orlando Faria, que perseguem os três em virtude de eles fazerem furtos na propriedade, roubando, por exemplo, penas de avestruz.

Orlando Faria, o Gordo, era "estancieiro de conceito no distrito, meio prefeito, meio delegado e meio uma porção de coisas que ele mesmo se nomeava e ninguém dizia que não". Contudo, o interessante é a narração da maneira como adquiriu suas terras:

\begin{abstract}
"Herdara da família um campinho de pouca bosta que logo começara a inchar. Emprestando a juro, amedrontando, escorraçando, abocanhara uma província ao arredor. Isso sem falar no que fizera ao João Fagundes. Por escassas quarenta braças que estorvavam um caminho, mandara estropiar o pobre velho. Solito no rancho, sem poder andar, morrera à míngua. Na beira do Inhanduí havia uma curz de pau, diziam que ali fora enterrado o velho. Diziam também que era ele a alma penada que, nas noites de vento, aparecia nos galpões, montada num petiço lunarejo, a mendigar uma tigela de pirão. Ninguém duvidava. Eram tantos os defuntos atribuídos ao Gordo, impossível que pelo menos um não errasse a porteira do céu e cá ficasse a penar sua aflição."
\end{abstract}

O fantasma da má distribuição de terras assombra ainda hoje o Brasil. E, no Rio Grande do Sul, não é diferente. Na região da fronteira sudoeste do Estado aparecem grande municípios (São Borja, Itaqui, Uruguaiana, Alegrete, Quarai, Rosário do Sul, Santana do Livramento, São Gabriel, Dom Pedrito, Bagé) de 4 a 7 mil quilômetros quadrados, contrapondo-se a uma malha municipal repleta de pequenas unidades territoriais ao norte de Porto Alegre e em todo o centro-norte do estado. No entanto, essas áreas de grandes municípios são as de menor densidade do Estado, onde predominam até hoje as grandes propriedades e a cobertura campestre.

Faraco, ao eleger esse espaço da Campanha nos seus contos, desnuda a realidade da má distribuição de terras e da maneira contraditória, questionável com que são adquiridas desde os primórdios dos tempos até hoje. E, como no passado, muitos estancieiros vêem nos acidentes geográficos os limites de suas terras. Era por isso que os personagens ansiavam por alcançar o rio, pois ele demarcava a divisa da propriedade do Gordo. 
Ao atravessar o Inhanduí, estariam livres do bando de Orlando Faria, qualificado pelo narrador como "ralé endemoniada, sem coração, que por casa e comida perdia o respeito até pelos parentes". E, embora o protagonista também aceite sua condição de ladrão, afirma que tanto ele, como Pacho e Maidana não se pareciam com o Gordo e seus homens, "gentio sem quimeras".

A diferença está no fato de a delinqüência do personagem-narrador e de seus companheiros ser motivada pela realidade sócio-econômica da exclusão, que instaura um reducionismo de oportunidades. Enquanto os atos ilícitos cometidos pelo Gordo transcendem a sobrevivência e instauram os valores da ganância, do individualismo, da descartabilidade. Este é um homem "sem coração" e quando o coração não existe, instaura-se a barbárie, "o salve-se quem puder", os "desvalores", o caos, uma desordem em que "ter coração" é vingar-se pela morte do companheiro, pela morte de Maidana, que, ao não querer prosseguir com o protagonista e Pacho, fora apanhado pelo bando adversário:

\footnotetext{
"Naquele cu do mundo, o que podia fazer um desgraçado senão ouvir a voz do coração? Alguém tinha de pagar e não só pelo Maidana. Também pela mulher que ia cair na vida, também pelo filho que, não morrendo pesteado, ia ser ladrão, que nem a gente."
}

Portanto, já do outro lado do rio, ao ver um capanga do Gordo, o protagonista ergue seu revólver e atira. O adversário cai de bruços entre as patas do cavalo. E, "como dois bichos, andando de quatro" os dois personagem se distanciam ouvindo os gritos do moribundo e, "de repente não se ouviu mais nada" e, então, voltam a caminhar.

Essa cena que encerra o conto, zoomorfiza tanto o narrador quanto Pacho, já que assumem condição de seres irracionais ao adotarem a política do "olho por olho dente por dente". Só quando o silêncio volta a reinar, eles levantam o corpo, mas voltam a caminhar "sem rumo" num contexto onde a degradação física e moral é chocante.

\section{8- "O vôo da garça-pequena"}

Em "O Vôo da garça-pequena", que foi publicado pela primeira vez em Noite de Matar um homem (1986) e constitui a nona narrativa de Contos Completos, 0 personagem López volta a aparecer e, com ele, apesar de ser contrabandista, uma visão 
menos ácida da vida na fronteira, uma vez que as narrativas que envolvem esse personagem passam-se num tempo mais distante do atual.

Nesse conto, o índice temporal é demarcado com precisão, uma vez que López promete trazer para Maria Rita, prostituta nova de o "La Garza", casa de mulheres do Alvear, vilarejo do outro lado do rio, um Philco vermelho de três ondas. Esse rádio de cabeceira começou a ser adquirido por moradores do Rio Grande do Sul e da região da fronteira em meados dos anos 50, data confirmada pelo conto "Legião Estrangeira", que pertence à terceira parte dos Contos Completos. Essa narrativa se passa em junho de 1957, e o personagem principal, morador da cidade, possui um rádio novo, um Philco de três ondas.

Maria Rita era nova naquele lugar que López costumava freqüentar. Vinda de Maçambará, cidade do Rio Grande do Sul, tinha deixado o marido que a surrava para fazer a vida. E Cocona, uma velha paraguaia e dona da casa, explicou a López que era uma mulher "metida a idéias". Maria Rita interessa-se por López, quando Cocona Ihe diz que ele era o "homem dos rádios" trazidos de Uruguaiana.

Para conseguir o rádio, Maria Rita aceita se deitar com López. Antes, conversam e fica evidente, tanto por meio da voz do narrador onisciente, como pela voz do próprio López, durante sua conversa com a prostituta, a mentalidade machista desse personagem contrabandista.

Quando Maria Rita afirma que era surrada pelo marido, e pergunta se ele achava isso certo, López responde que se é por traição até pode ser, mas surrar de graça para ele é condenável. Além disso, afirma que homem só dá valor à mulher "na hora de se aliviar."

E quando a prostituta lhe diz que mulher também faz outra coisa, López concorda:

“- Por supuesto - quis logo concordar. - Elas cozinham, remendam, plancham, dão cria, imagine o que ia ser da gente..."

Então Maria Rita diz que ouviu dizer que em Uruguaiana, em Itaqui ou em São Borja, não sabia ao certo, havia uma mulher doutora, que trabalhava no hospital. E para saber do que se passava pelo mundo, em Porto Alegre, para ter idéias é que queria o rádio.

López conclui: 
"Pronto, pensou López, ali estava o que Cocona queria dizer, uma mulher de idéias. Com certeza era mais uma querendo virar homem, como a tal doutora de São Borja e uma outra que ele mesmo tinha visto, a professora da Vila do Bororé fazendo um discurso. Mulher fazendo discurso, era só o que faltava. Ela suava no bigode. Meus correligionários, ela gritava, e suava no bigode. Um baixinho de boina retrucou que a dona precisava mesmo era de um pau-de-mijo para sossegar dos nervos."

É, dessa forma, por meio de Maria Rita que Faraco contextualiza a situação da mulher em meados dos anos 50 na região da fronteira, sem oportunidades educacionais, sociais e culturais, mas já com o desejo de romper o estabelecido para galgar novos espaços.

As mulheres das décadas de 1950 e 1960 pertencem a um contexto histórico específico. Nos anos 50, logo após a Segunda Guerra Mundial, as potências mundiais capitaneadas pelos Estados Unidos e União Soviética (URSS) iniciaram a "Guerra Fria", quando o mundo viveu o perigo de uma nova guerra mundial, agora com bombas atômicas. No mesmo período, o Brasil vivia uma fase democrática em que os presidentes eram eleitos com voto direto e secreto.

Porém a sociedade brasileira continuava extremamente conservadora e patriarcal, o que exercia forte influência na vida de muitas mulheres, que seguiam o modelo imposto se dedicando somente ao lar. Essa tendência dificultou bastante a emancipação feminina no Brasil. As pessoas casavam cedo e tinham muitos filhos. Nesse contexto, a mulher, além de bela e bem cuidada, devia ser boa dona-de-casa, esposa dedicada e mãe atenciosa.

Por outro lado, naquela época, as pessoas começaram a viver uma frenética busca pelo novo, pelo conforto e pelo consumo. A partir da década de 1960, a televisão, tendo como base os Estados Unidos, se populariza o que permitia às pessoas assistirem aos acontecimentos que cercavam os ricos e famosos, com seus luxos, prazeres e elegância. Exemplo desta interface foi o casamento da atriz Grace Kelly com o príncipe Rainier, de Mônaco.

No Brasil, o grande veículo de comunicação ainda era o rádio, que fazia primordialmente transmissão de esportes, de novelas mexicanas e de programas de auditório, via rádios Nacional e Tupi. A TV ainda era um aparelho de luxo que só as 
classes altas podiam ter. É nesse contexto, que Maria Rita deseja um rádio, mesmo que para isso tenha que se prostituir.

Dentro desse panorama, o contrabando na região da fronteira também se acirra uma vez que o desejo por produtos que trazem conforto ou informação intensifica-se. $E$ López, nas suas eternas travessias pelo rio, de um para outro lado da fronteira, representa bem esse fenômeno.

Finalmente, quando aquela mulher "cheia de idéias" o convida para deitar, ele se levanta e vai embora, porém promete o rádio a Maria Rita e diz que ela não precisará pagar nada por ele.

O conto se fecha com a descrição da debandada dos bichos que estranhavam a passagem de López, no caminho de volta para o barco:

“... e de um ninho de gravetos, na moita de um sarandi, alçou vôo a mais graciosa de todas as aves do banhado, a garça-pequena com seu véu de noiva, suas plumas alvíssimas, e voava longe, para o alto, e era o vôo mais tristonho e mais bonito. López talvez a tenha visto. Ou talvez não."

Uma delicada descrição que se refere às mulheres, que alçaram e continuam alçando altos vôos, "bonitos", porém "tristonhos", já que ainda enfrentam inúmeros obstáculos para consolidarem seus ideais sociais, políticos e culturais numa sociedade que não possui discernimento suficiente para entender que a posição equilibrada não é mulher na frente e homem atrás ou vice-versa, mas sim a do lado a lado, numa relação de oposição e complementariedade.

"O vôo da garça-pequena" transcende os limites regionais e presta um tributo às mulheres gaúchas, brasileiras no geral. E se López não enxerga a "ave tão graciosa", Faraco a visualiza e pousa seu olhar sobre ela, colocando-a como parte importante de sua literatura, que sempre "visa salvar alguém de algo".

\section{9- "Bugio Amarelo" e "Adeus aos passarinhos"}

"Bugio Amarelo" é o décimo conto da primeira parte do livro Contos Completos. Como esperado, é narrado em $1^{a}$ pessoa, e as ações se localizam mais próximas do tempo presente. 
Esse conto surgiu em Hombre (1978) e possuía um título diferente: "O massacre do Bugio Amarelo". Essa mudança se justifica. Faraco, como já comentado anteriormente, prima pela precisão e sempre que republica um conto, certamente faz algumas alterações que até passam imperceptíveis.

Nesse conto, o narrador-personagem, pernoita no quintal da casa de seu amigo Amâncio, que fora a Monte Caseros, Argentina, para comprar duzentas caixas de balas incendiárias, "com venda certa para lavoureiros da região, por causa das caturras."

Como se sabe ainda hoje é comum nas zonas fronteiriças do Rio Grande do Sul, em pequenas propriedades com lavouras, o emprego dessa espécie de munição para destruir ninhos de caturras no alto dos eucaliptos. As balas incendiárias, cuja venda é proibida no Brasil, são contrabandeadas da Argentina.

É o personagem-narrador que afirma que esse tipo de encomenda era rejeitada por muitos chibeiros porque tinham medo da lei. Mas, "já que os tempos eram duros, os grandes lances iam rareando", eles precisavam se contentar com migalhas.

Amâncio antes de subir o rio nessa empreitada, pede ao personagem-narrador para zelar pelo bebê que estava doente. Em caso de precisão, o farmacêutico deveria ser chamado. Na casa, também dormia Zélia, esposa de Amâncio.

De repente, o protagonista ouve seu amigo Bagre chegar no pátio e lhe dizer que tinha "bugio no bananal do Amâncio." Bagre se referia ao alemão da pulperia que tinha entrado na casa do amigo para ficar com Zélia:

\begin{abstract}
"Não era novo o disque-disque de que Zélia andava a pagar em natureza uma conta de leite ao pulpeiro. Duvidávamos, era sempre a Zélia, mulher do nosso Amâncio. E logo com quem, o alemão da pulperia. Aquele sim, não prestava. Bugio, Bugio Amarelo, assim era chamado por ser peludo de torso e dorso, um pêlo baio que de tão cerrado parecia uma doença. Carrasco da desgraça alheia e desavergonhado, roubava no quilo e na tabuada, corvoejava os precisados para castigar no juro e na hora do acerto não era nem parente. Ferro e fogo. De um jeito ou de outro o infeliz pagava, nem que fosse com os encantos da mulher."
\end{abstract}

É significativo ser um alemão o homem que desperta a raiva do protagonista. É interessante lembrar que a aversão ao estrangeiro é uma suposta característica do Rio Grande em formação do século XIX, acentuada pelo fato de os primeiros imigrantes 
alemães prosperarem rapidamente. A princípio, dentro desse contexto, podemos até supor que o tamanho ódio do protagonista pelo alemão, além de ser justificado por este se tratar de um homem desonesto e impetuoso, também pode ter raízes culturais.

René E. Gertz, professor de História da PUCRS e da UFRGS, aponta que desde o início da imigração alemã "há prevenções contra a presença de alemães e descendentes em virtude de sua suposta inadaptabilidade ao meio riograndense (...). Evidentemente, os alemães destovam do contexto gaúcho desde o ponto de vista biológico (os famosos "cabelos loiros e olhos azuis") até o ponto de vista lingüístico (não havia nenhuma semelhança entre a língua alemã e portuguesa) e cultural (há diferenças no modo de vida, de alimentação e, não por último, de religião)." Porém, Gertz sustenta que "apesar das diferenças raciais, culturais e apesar da concentração dos imigrantes alemães em áreas específicas, apesar de todos os elementos adversos para uma integração, essa integração, no seu conjunto, foi muito mais bem-sucedida do que muitas vezes se pensa."

A aversão do protagonista ao "de fora" aumenta, quando pensa que seu amigo Amâncio está se arriscando para trazer o sustento da família, enquanto Zélia o engana "com o alarife". Nesse contexto, fica claro que seu ódio em relação ao outro não se justifica apenas por ele ser um alemão, mas por ele ser um estranho que viola os ideais gaúchos de "honra, amizade e lealdade, valores sagrados e intocáveis, inerentes à sociedade campeira".

Decide, então, entrar na casa e surpreender os dois. Consegue surrar o Bugio amarelo, mas também é surrado por ele. No entanto, o alemão foge, enquanto ele permanece sozinho com Zélia que o seduz em troca do seu silêncio.

Nesse momento, o personagem principal iguala-se ao inimigo porque há traição, deslealdade em relação a Amâncio. Rompe-se, então, o estereótipo de o gaúcho ser "superior" ao "de fora" por sustentar um código de honra particular que compõe sua identidade.

Todavia, ao sair da casa, pede para o Bugre não comentar nada para ninguém sobre Zélia e o Bugio. Decide, então, ir embora da cidade, ato que funciona como uma espécie de purgação diante da traição cometida. Antes de partir, encontra Amâncio e the dá um longo abraço. Também passa na pulperia para uma visita ao alemão: 
"Mas não deixei a cidade assim, como quem vai para outro mundo e lega aos amigos uma arroba de fracassos. Passei na pulperia para uma visita ao alemão. Entrei, pedi à freguesia que se arredasse. Cerquei-o num canto do balcão, ele com a faquinha de picar fumo, eu com meu soco inglês. Do que aconteceu não me arrependo, mas não quero recordar. Para saber, querendo, é perguntar aos antigos chalaneiros do rio, em Uruguaiana, em Itaqui, em Barra do Quarai. É perguntar ao Bagre. Nem tanto pela verdade, que ele falseia um pouco, mais pelo floreio, ao qual não nego certo encanto. "Quando o Bugio chegou no céu...", começa ele."

Como sustenta Gilda Bittencourt, o protagonista "elimina o Bugio Amarelo (...) para devolver àquele universo, ao qual não pertence mais, a integridade e a simplicidade honesta de antes, numa tentativa de conservar intacta uma imagem idealizada do mundo de sua juventude."

Assim, apesar de ter cometido a mesma traição não perdoa o outro, embora se iguale a ele. O que predomina é a questão de "lavar a honra", característica do "gaúcho de cepa", que ao narrar seus "casos" falseia um pouco a verdade; no entanto, mesmo assim, o encantamento é garantido.

A voz narrativa desse conto que remete a um suposto interlocutor ("para saber, querendo, é perguntar aos antigos chalaneiros do rio"), como se tivesse a desfiar um "causo" ao modo de Blau, também confessa que se sente atraída por essas histórias que mitificam as atitudes do gaúcho, como bravo, honrado, honesto. No entanto essa atração não se dá apenas pelo conteúdo das histórias, que pode ser verdadeiro ou não, mas pela forma pela qual são desfiadas, com os floreios, tão caros aos contadores de causos, cuja "técnica" é absorvida por homens das letras, como Sergio Faraco. Dessa forma, apesar de evidenciarem a extrema miséria, também revelam, pelos caminhos "misteriosos" da literatura, o encanto desse mundo fronteiriço, que se baseia nas trocas de linguagem, de vivências e se encontra acima das imposições ideológicas. Logo, comporta uma identidade ímpar.

No entanto, quando o personagem-narrador decide deixar esse mundo, ele acaba por se perder, como fica evidenciado no próximo conto, "Adeus aos passarinhos", que foi publicado pela primeira vez em Noite de Matar um homem (1986). É o décimo primeiro conto da primeira parte de Contos Completos e evidencia as divagações do "eu" que abandona a sua terra. Assim, essa narrativa mostra toda a angústia dessa decisão por uma espécie de monólogo interior. 
Na verdade, o "eu narrador" se dá conta que sua "chalana" tão pequena agora enfrenta, freqüenta o mar, metáfora ligada à vastidão do mundo, a que ele se entrega.

Nas suas constantes memórias aparece o menino dos "velhos tempos" cheio de vida que se confronta com o que ele se tornou: "um monstro", um zumbi, meio vivo, meio morto. Eis que surge a impressão de falta de raízes, de busca por alguma coisa, que ao certo não sabe o que é. Há uma sensação de não pertencer ao "mar" a que foi jogado, uma impressão de falta de um lugar que lhe conceda a condição de "ser", pois sente um nítido estrangulamento frente àquela vastidão. E o passar do tempo simplesmente zune dentro dele como um inseto "sem rumo".

Permanece a sensação de desamparo não só daqueles que miseravelmente vivem no campo, ou nos pequenos povoados, mas também impera a angústia quando o homem afasta-se da terra natal. A sensação que prevalece, por meio do personagem de Faraco, como também vimos no caso do personagem Reyles de Arregui do conto "Noche de San Juan", é a de um homem que questiona sobre sua vida e seu lugar; são "náufragos arrojados pelo destino na concavidade de uma mesma onda".

E quem pode "salvar" esse homem? O próximo conto parece delinear a reposta para a questão.

\subsection{1- "Sesmarias do urutau mugidor"}

"Sesmarias do urutau mugidor", que apareceu pela primeira vez em 1978, no livro de contos $\underline{\text { Hombre }}$, é o décimo segundo conto da primeira parte de $\underline{\text { Contos Completos. }}$

A narração em primeira pessoa, diferentemente dos contos anteriores, não traz a voz de um morador da fronteira, mas sim de um escritor de Porto Alegre que está de mudança para Uruguaiana. No caminho, desvia-se de sua trajetória e, depois de muita chuva, tem problemas com o seu carro. Pede, então, abrigo a um velho gaúcho que mora com sua filha à beira da estradinha em um rancho pobre.

Quando o velho o convida para entrar, pois já estava anoitecendo, e lhe pergunta se ele estava "chibando pra Corrientes", ele responde que não. Carregava coisas pessoais, roupa e muitos livros, "porque gostava deles e gostava tanto que de vez em quando escrevia algum." 
Nesse momento, fica claro que o persongem é o alter-ego de Sergio Faraco. O personagem demonstra sempre a intenção de "salvar alguém de alguma coisa", assim como Faraco:

"Passados tantos anos, mais de trinta desde meu primeiro livro, constato que em boa parte dos meus contos há uma tentativa de salvar alguém de alguma coisa, ou salvar um sentimento, ou uma esperança, salvar quando menos um resto de dignidade."

Nesse conto, por meio do personagem, Faraco discute a sua necessidade de penetrar naquele "mundo agônico" da Campanha, dos rincões habitados por velhos gaúchos, esquecidos pelos estancieiros. E a democracia no ambiente rural existente entre senhores e subordinados cai do seu patamar mítico, quando o velho, que vive na miséria com sua filha, lança queixas amargas contra "os estancieiros que por quarenta anos o tinham procurado nas horas de aperto e que agora, na velhice, deixavam-no de lado, como um rebenque velho."

Era ele quem, quando jovem, tomava conta da estância do Urutau, que possuía cento e tantas quadras de sesmaria no passado, mas que já estava repartida pela filharada do velho estancieiro chamado Querenciano. A ele, agora, restava uma vida de miséria naquele rincão.

Urutau, nome da estância, mas também de uma ave noturna do Rio Grande do Sul, cujo lastimoso canto se assemelha a vozes humanas gritando de longe. Assim, é de longe, é distante das grandes cidades que o velho gaúcho grita para alguém ouvi-lo?

Após se embriagar, o velho cai no sono. O escritor, apesar de alguma resistência (de não querer penetrar nesse mundo?), fica com Maria, a filha do velho. Se, a princípio, ela lhe causa estranhamento por ser muito semelhante, pelo seu físico e pelas suas roupas, a um rapaz, depois ele se entrega aos seus rudes encantos. Maria é a metáfora de que ele aceita o desafio de desvendar aquele mundo "gasto", mundo agro-pastoril em decadência, alicerçados em mitos que já não se sustentam mais. Mundo que, a princípio, estranha, mas que aceita penetrar "com amor", "para tornar menos doloroso o elo partido".

Esse amor provém de sua profissão de escritor, pois sustenta que, para escrever, "a cabeça ajudava por certo, mas, mais do que a cabeça, valia o coração", para, por 
meio da letra, desvendar "uma nova ordem", mas não nutrida da velha, "oposta àquele mundo compacto não dilacerado pela cidade e pelo asfalto das novas estradas".

Nesse trecho, fica evidente a discussão instaurada por Faraco a respeito da identidade cultural gaúcha, forjada na zona agro-pastoril, na velha ordem, que sempre foi liderada por forças detentoras do latifúndio que impedem a igualdade social. $\mathrm{E}$ tocar nessa questão é "romper um elo da frágil corrente que o sustentava", uma vez que essa ordem forjou a identidade do gaúcho-herói; é colocar em discussão os atributos do herói, cujos valores são sustentados por essa classe dominante. Por outro lado, o rompimento desse elo, pode significar liberdade para detectar os determinismos indesejáveis e transpô-los, a fim de evidenciar especificidades dessa região e, por meio da linguagem, da literatura, organizar o caos da realidade e gerar uma teia de significações que possibilitem a reflexão e a interação com esse meio, cercado de misérias.

\subsection{2- "Hombre"}

A miséria do homem fronteiriço reside também nas periferias das cidades de fronteiras, onde habitam os personagens de Faraco. E em "Hombre", décima terceira narrativa da primeira parte dos $\underline{\text { Contos Completos, }}$ mais uma vez a triste realidade que atinge a vida de seus moradores é colocada em cena.

"Hombre" foi publicado pela primeira vez em 1978, no livro de contos que recebe o mesmo nome. O enredo focaliza a volta do narrador-personagem que, no conto "Bugio Amarelo", deixa a zona fronteiriça e vai para a capital do Rio Grande do Sul. Ele regressa porque era dia de batizado do filho de Pacho, seu afilhado.

O que chama a atenção é a narrativa abrir com os seguintes dizeres:

"Pacho me dissera que a vida tinha mudado, que agora os estancieiros mantinham severa vigilância no rio, nos matos, nos pastos."

Dez anos separam a partida do narrador-personagem para a cidade grande da ação desse conto, como verificado no diálogo entre Pacho e ele. E o que se verifica é que a exclusão aumenta, à medida que o tempo da narrativa, embora não demarcado com precisão, vai ficando mais próximo ao presente, ao tempo da escrita. Dessa forma, a situação dos contrabandistas, dos "homens do rio", "dos capincheiros" da zona fronteiriça só se agrava com o passar dos anos, como constata Pacho: 
“Tourn, Eugenio Tourn, era um correntino abonado, proprietário de campos e matos na costa do Uruguai, e já havia alguns anos, que, com o apoio das autoridades, prometera exterminar os capincheiros da região. Aquela gente que empreitava na cidade, dita maleva e traicionera pelos homens do rio, acampava mato com comes e bebes a la farta e do mato só saía com idéia ruim. Não hesitavam em desgraçar um homem por causa de um reiúno baleado, e pouco lhes importava que aquela carne fedida tivesse por destino o bucho dos barrigudinhos que perambulavam, acá y allá, pela mísera ribeira. Não, antes as coisas não eram assim, tão descaradas, e agora eu começava a acreditar nas fantásticas histórias que Pacho só destrançava depois de um quinto gole de canguara."

A lei e os estancieiros são o inimigo para Pacho, pois os donos de terras "se adonaram de tudo", num contexto onde vigora o "olho por olho, dente por dente". E se os "outros" eram imundos, eles também se tornavam, porque "se acostumam com tudo," e embora pressentissem a necessidade de mudanças, naturalizavam a caótica situação.

Quando o narrador-personagem, no momento que está no barco, indaga que jamais se acostumaria de novo com a situação do contrabando, Pacho responde:

"-Tu é um bosta, por isso não queria te trazer. Tu era gente boa, todo mundo aqui te queria bem, te admirava, o Agostinho, o finado Testão, o Pedro Sujo, o Bagre, o pessoal ficava conversando fiado nos bolichos, que capivara de holofote era a marcação da tua vinchester, correntino de quepe o dengue do teu soco inglês. Tu tinha fama e te digo mais, até eu, que sou eu, ficava te invejando. Tu era grande, tu era gente nossa. (...)

- Trocou o rio pela cidade, pela capital, virou homem de delicadezas, empregado de patrão, trocando a amizade dos amigos pelo esculacho dos endinheirados. Pra que serve tudo isso? Agora taí, um pobre-diabo que não presta mais pra nada. Dispara feio num capincho e no primeiro entrevero se borra nas calças."

Nesse conto, o personagem "de dentro" torna-se "o de fora" do universo de honra gaúcho, ou seja, o personagem-narrador, apesar de considerar os antigos valores, já não consegue conservar a valentia, objetivo de Pacho.

Vale ressaltar que o perfil valente do gaúcho rio-grandense construiu-se "em torno do tema "do entalhador de fronteiras, nas escaramuças com os castelhanos", e esse perfil lendário continua a contagiar a memória coletiva dos habitantes da zona fronteiriça. 
Meneses esclarece que memória é o mecanismo de retenção da informação, conhecimento, experiência, quer em nível individual, quer social, e por isso mesmo, é eixo de atribuições, que articula, categoriza, os aspectos multiformes da realidade.

Le Goff afirma que a memória popular coletiva se cristaliza entre as populações, principalmente no que diz respeito aos mitos de suas origens étnicas. Esse tipo de memória concede muitas liberdades aos seus portadores e cria inúmeras possibilidades de variações.

Embora por volta dos anos 1920, as características de valente e guerreiro atribuídas ao gaúcho, tenham sido apossadas e, de certo modo, "geradas" pela ideologia dominante, como observado anteriormente, elas vão, indubitavelmente, permanecer no imaginário popular e se manifestam ainda hoje, pois Pacho, a seu modo, é leal, é corajoso, atributos que contrastam com a vida do narrador-personagem que se entregou ao cotidiano da capital e, agora, não sabe nem manejar uma arma; tornou-se um covarde.

Depois do desabafo, Pacho pede desculpas. Ambos, então, começam a beber e a contar velhos casos. E Pacho falava "dos amigos mortos, homens que tenían algo más que leche en los cojones,", ou seja, eram, sob uma nova capa da realidade, bravos, valentes e mantinham a essência que moldou o gaúcho-herói do passado.

\subsection{3- "Velhos"}

Novamente "velhos" gaúchos são colocados em cena no último conto da primeira parte do livro Contos Completos, intitulado "Velhos".

O narrador onisciente coloca em evidência, novamente, a vida de gaúchos, já idosos, que foram capatazes de estâncias e ainda moravam com sua família nessas fazendas, embora não exercessem mais atividade, pois a idade os impossibilitava.

O personagem que se destaca é o velho Cuertino López, o mesmo personagem do conto "Lá no Campo". Porém, nessa narrativa, ele se encontra já fora de atividade, num tempo mais próximo ao presente. 
A ação se desenvolve num domingo, quando Cuertino e sua mulher, Santa, esperam a visita do seu irmão, Sizenando López e de sua esposa, Dona Bica. Esse ritual se repetia há quinze anos, desde que Sizenando "viera capatazear um estabelecimento lindeiro". Todos os domingos eles se visitavam: num, ia Cuertino e Dona Santa, noutro, vinham Sizenando e Dona Bica.

Cuertino, antigo capataz do pai de "Dona Maria Luíza Santos Trindade", está preocupado, pois confessa a Sizenando que descobriu que o filho, Neco, andava pulando a janela do quarto da moça.

A preocupação não se limita apenas pelo fato de ela ser a herdeira, dona da estância. A questão é que era comprometida, e o noivo vinha visitá-la todo domingo, apesar de, cada vez mais, estar ficando menos tempo com ela.

É Sizenando que conclui sobre o envolvimento de Neco com Dona Maria Luiza:

"-Pois a mim, como meio pai, me palpita que esse enleio é mixe e dá de desenlear.

- Não sei... há coisas que um velho não pode fazer.

- Mas dois velhos podem."

Então o tio conclui que o jeito era tirar o sobrinho dali, pois, na casa estância onde habitava, havia uma peona que viera da cidade e , como menciona, "era chirua faceira" e estava "pedindo um calor nessas noites frias".

De volta para casa, o tio encontra Neco:

"-A bênção, tio.

- Deus te abençoe, sem vergonha - disse o velho Size, sem deter-se."

(...)

- Que foi que eu fiz, tio? - perguntou, humildemente.

- Por enquanto, quase nada - disse o velho, sem olhar para trás -, mas te garanto que, de amanhã por diante, vais ter muito o que fazer. Já pra casa!" 
Se muitos contos de Faraco evidenciam a vida daqueles que saíram do campo e compõem "os cinturões de miséria" das periferias das cidades de fronteiras, alguns deles evidenciam como é a vida dos peões que ficaram nas estâncias.

Embora, nesse último conto, não haja a "mancha descritiva" que caracteriza os pormenores do ambiente rural, há a descrição dos costumes ainda presentes no campo:

"Depois do almoço, em que comeram carreteiro e canjica, sestearam no galpão. Da meiágua vinham ruídos de pratos e as vozes incansáveis de Dona Santa e Dona Bica."

"Ficaram calados, imersos em seus pensamentos, até que vieram as mulheres. Sizenando e Dona Bica foram cumprimentar os donos da estância, que os receberam na varanda. Depois de uns minutos, despediram-se, Dona Bica sobraçando um queijo, que ganhou da mãe de Maria Luíza, e uma bolsa de roupas com pouco uso, presente da menina."

Essa narrativa não afirma a democracia entre patrões e subordinados sustentada por uma historiografia das primeiras décadas dos anos 1900, todavia evidencia que há, sim, certa cordialidade entre eles.

Por outro lado, fica evidente que, para os "velhos", é um absurdo haver um romance entre um morador da "casa grande" com um que habita o "galpão"; assim o objetivo é afastar Neco de Maria Luiza a qualquer custo, embora, em muitos momentos, fique nítido que os velhos admiram a atitude de Neco, sua hombridade, ao se relacionar com uma "piguancha" do "pêlo" de Maria Luíza.

Portanto, o imaginário do gaúcho do campo, macho, atraente, ainda perdura no imaginário coletivo, embora ele habite uma "meiágua" nas estâncias. 


\section{CONCLUSÃO}

Sergio Faraco e Mario Arregui jamais se remetem ao passado como "um paraíso perdido", para endossar o mito do "gaúcho-herói". Isso significa que negam a construção ideologizada desse estereótipo, tanto no Brasil como no Uruguai, por historiadores e literatos, que no "processo de construção de uma figura unificadora, passaram por cima das mais diversas clivagens de ordem social, econômica, étnica e cultural operando com a idéia da existência de uma homogeneidade, que se sobreporia a todas as diferenças e contradições internas, o que faz que estas figuras sejam politicamente plásticas podendo sofrer apropriações e utilizações as mais diversas."

A apropriação do "gaucho" e do "gaúcho", no século XX, ocorre por volta dos anos 1900 a 1930, já que, por meio da literatura e da historiografia, tal figura tornou-se "emblemática". No Brasil, como analisamos, surgiu toda uma literatura, com exceção da de Simões Lopes Netto, ligada à construção, segundo Mario Maestri, do gaúcho "hermafrodita", pois ele foi ideologizado para possuir "os atributos não contraditórios do fazendeiro e do peão", a fim de criar o mito da democracia no campo, embora os estancieiros já tivessem perdido o domínio econômico no Rio Grande do Sul. 
Além disso, tanto a historiografia de vertente lusa como a literatura operavam para criar uma identidade brasileira para o Sul do país negando as influências do Prata, visto que o objetivo era projetar a figura de Getúlio Vargas ao governo central. A meta, além de "abrasileirar" o Rio Grande do Sul, era "agauchar" o Brasil; afinal, havia a necessidade de convencer o país de que só um "gaúcho de cepa", com toda a sua "coragem, lealdade e valentia" poderia governar o país. Surge, então, a figura "identitária do gaúcho" "para establilizar o mundo social".

No Uruguai, também nos anos 1920, predomina, com a exceção da obra de Javier Vianna, que colocou seus textos a serviço do povo mais pobre, uma literatura a serviço dos estancieiros. São textos, como de Elias Regules, que se apossam da figura do "gaucho" dos primeiros tempos, atribuindo-Ihe força, altivez, para criar uma identificação com ela, a fim de mascarar a realidade dos "gauchos" ou "paisanos gauchos" que viviam em taperas.

Num contexto geral, podemos afirmar que muitos textos do regionalismo brasileiro e uruguaio das duas primeiras décadas do século $X X$, assemelham-se a aspectos da literatura gauchesca do Prata dos primeiros tempos, cujo objetivo era transmitir uma mensagem que escamoteava a realidade presente em nome de uma ideologia dominante que manejava o passado.

Porém, a literatura de Faraco e Arregui aproxima-se, na abordagem temática, da gauchesca de José Hernandéz que, com o Martín Fierro, já em 1872, deu feição ao homem pobre do campo, cuja voz ecoou não só no horizonte de outros "gauchos" e gaúchos, mas também no universo do leitor culto.

Nesse sentido, o público a que Faraco e Arregui visam atingir é o composto por aqueles que vivem a realidade atual das cidades de Fronteira, espaço onde muitos dos contos são ambientados, mas, sobretudo, o composto por leitores de conhecimento erudito.

E, embora muitos contos de Arregui ("El regresso de Odisseo González", "Los contrabandistas", "Tres Hombres", "Un cuento con un pozo", "La escoba de la bruja”) retomem o passado, em nenhum momento pretendem manejar o presente por meio de personagens caracterizados para servir a interesses dominantes, como acontecia na literatura de Hilário Ascasubi (1807-1873), poeta argentino, de Estanislao Del Campo (1834-1880) ou de Elias Regules, denominada de "gauchesca decorativa" por Arregui. 
Quando coloca o "gaucho" do século XIX em cena, o escritor uruguaio visa desmistificá-lo, desconstruir a identificação do povo uruguaio com o "heroe-gaucho", para trazer à tona os determinismos indesejáveis que cercaram e continuam cercando a vida desse homem "de carne e osso".

Nesse contexto, quando Arregui diz que não é um "criollista", ele se remete a um tipo de literatura "campesina, campera ou rural" que prestou serviços a uma ideologia clara, cujos cantos ao gaúcho de antes e elegias à pobreza substituiam a crua realidade. Para Arregui, sua literatura até pode estar ligada à paisagem rural, mas o que não pode ocorrer é a ambientação estar diretamente associada a um homem do campo, ou "criollo", descendente do "gaucho", visto como herói positivo. Tudo isso ligado a poucos temas, com personagens humildes que aceitam seu "subdesenvolvimento" num tom de nostalgia, transmitida por um espanhol semi-dialetal, não compõem sua literatura.

Por esse viés, podemos concluir que Arregui nega esse tipo de "criollismo" o que equivaleria a um tipo de "regionalismo" também negado por Faraco, porque o gaúcho do escritor brasileiro é o "simples gaúcho", contrabandista num contexto onde as cercas predominam. É um guerreiro, no sentido de lutar contra os obstáculos de sua miséria física e moral. Mas é fiel à caracterização do passado, porque, como os gaúchos lendários, conserva a palavra empenhada ; é fiel ao passado porque é um contador de histórias, como o velho Blau.

Porém as técnicas literárias de Arregui e Faraco na retomada desse homem ou de seus descendentes são diferentes.

Arregui pertence a uma geração que tentou se afastar da literatura espanhola e da tradição gauchesca. Visava à ruptura com o realismo europeu, e supunha que seus textos deveriam comportar a presença alternada com outros tipos de narradores; o desaparecimento dos quadros descritivos; a presença de trechos não ligados com os segmentos precedentes e o trabalho intertextual. Quanto à literatura gauchesca, apesar de reconhecer o valor de Martín Fierro, questionava a sua autenticidade, porque não foi obra de "gauchos", pois quem estava por trás dela era um escritor culto.

Na verdade manifesta-se uma relação de aproximação e repúdio de Arregui em relação à literatura que trata do "gaucho". Porém, o escritor uruguaio sente a necessidade de retomar essa figura que, segundo ele, ganharia em "humanidade e 
naturalidade", se fosse abordada por meio dos "cuentos de fogón", narrativas orais contadas "ao pé do fogão" pelo "paisano-gaucho". Esses "cuentos" trazem episódios de guerras, superstições, sem a mitificação da bravura e coragem do "gaucho".

Ao tomar contato com os "cuentos de fogón" e seus narradores, Arregui busca reproduzir esse gênero "lindo y menor" nas seguintes narrativas: "Un cuento de fogón", "Contaba don Claudio" e "El caballo piadoso". Esses "cuentos" de Mario Arregui são recheados de superstições, de horas de combate, onde o "gaucho" sente medo e há apenas um heroísmo parcial. Apesar de eles serem contagiados pela figura de "bravura" do homem "de la Pampa", mostram a sua vida cortada por cercas; apontam o contato entre uruguaio e brasileiros; evidenciam a miscigenação do povo uruguaio, não formado de uma única raça, a do "gaucho", mas também da mistura do índio e do negro, embora Arregui reconheça que muito da cultura do Uruguai nasce com o "gaucho".

Na reprodução dos "cuentos de fogón”, Arregui utiliza uma das técnicas para romper com o "canón realista" que negava: além da presença de um narrador onisciente, que, apesar de ser culto, evidencia o "sentir" das personagens, há a manifestação de um outro, a do prórpio Arregui, que faz questão de demarcar sua presença, para recuperar os sentimentos das personagens por meio de uma visão mais intimista. Em momento algum, cede a voz ao personagem, mas intermedeia a narração com frases como "contaba don Claudio que...". Assim o narrador apossa-se dos "casos", que passam pelo viés interpretativo do autor culto.

Por meio da técnica de inserir sua voz culta na narrativa e demarcar claramente a distância entre o mundo do narrador e do personagem, Arregui almeja a romper com aquilo que repudiava na literatura criollista: narradores que "fingen ser más incultos de lo que en realidad son". No entanto, dependendo do ponto de vista, essa "artificialidade", que tem a ver com a voz, também se fará presente nos seus "cuentos de fogón". Se julgarmos que Arregui mantém o narrador onisciente culto e faz questão de trazer explicitamente suas opiniões de autor para confirmar que a narrativa está sendo exposta por alguém de conhecimento erudito, podemos afirmar que não há artificialidade. Por outro lado, quem narrava esses "casos", eram, como o próprio Arregui menciona, "crioyos", e, talvez, os "relatos" pudessem ganhar um novo brilho se o escritor cedesse a voz ao homem do campo. 
Todavia é justificável que Arregui não tenha utilizado essa técnica, em virtude de pertencer à geração de 45, que "reclamava uma elevação intelectual e artística e supunha uma formação que transcendia as limitações campeiras". Porém, muitos dos temas dos seus contos são ligados à tradição; por isso a constatação de que esse autor transita, está na fronteira entre "a tradição e a vanguarda".

O "autêntico", buscado por Arregui, tem mais a ver com o distanciamento do "canón realista". Nesse contexto, ao reproduzir "cuentos de fogón”, Arregui busca a inovação da figura do "gaucho", por meio de técnicas narrativas específicas, como a presença de um narrador-autor que mostra o cotidiano de "dores e prazeres" do homem do campo e, assim, tanto por meio do conteúdo, como da forma, opõem-se aos modelos da "gauchesca decorativa" ou a um certo tipo de "criollismo".

Entretanto, como já observou Angél Rama, é a partir dos anos 60, que Arregui dá uma trégua na construção de contos que primam pela eterna busca de essências e escreve narrativas com temas menos densos, porém não superficiais.

Na verdade, Rama está se referindo aos "cuentos de fogón" e a muitos dos contos que retomam a figura do "gaucho". Com exceção de "Noche de San Juan", onde há a presença do narrador onisciente culto que penetra na psicologia do "paisano gaucho" Francisco Reyles, proporcionando-Ihe densidade psicológica, publicado em 1956, e de "Diego Alonso" também publicado nesse ano, os outros contos que falam desse homem do campo, fronteiriço surgem a partir dos anos 60 .

Esse "amadurecer" da obra de Arregui, a partir dos anos 1960, ligado a um olhar mais atento à sociedade, coincide com o advento do capitalismo Industrial e do capital internacional. Assim, no Uruguai, surge não só a necessidade de buscar a identidade desse povo, ameaçada pela homogeneização do Industrialismo, mas também a necessidade de crítica à literatura das primeiras décadas dos anos 1900 que usava a figura do "gaucho" atrelada à ideologia da manutenção do poder político e econômico dos latifundiários frente à modernização do país e à chegada dos imigrantes.

São em momentos de crise, num conflito estreito com a modernização e industrialização que vai aflorar uma literatura de Arregui que visa à retomada das particularidades locais, do modo de ser desse homem que habita a região da Fronteira; ou seja, a busca pela "identidade somente se torna uma questão quando ela está em 
crise, quando algo que se supõe como fixo, coerente e estável é deslocado pela experiência da dúvida e da incerteza".

Como já abordado, uma intensa crise se iniciou, a partir de 1955, no Uruguai e seguiu até o golpe militar em 1973. E não é por coincidência que os contos de Arregui, que tratam do "gaucho", começam a surgir a partir de 1956, pois frente à mudança de hegemonia no mundo capitalista, frente a um processo mercadológico liberal homogeneizador liderado pelas forças estadunidenses que vai desembocar no que modernamente chamamos de globalização, o que restará da cultura uruguaia?

Nesse contexto, muitos das narrativas de Arregui retomam essa figura, num enredo, na maioria dos contos, localizado no passado: o conto "El regresso de Odiseo Gonzálvez", publicado em 1972, se passa em 1820; "Los Contrabandistas”, publicado em 1960, embora o tempo da ação não seja precisamente demarcado, ocorre no final do século XIX; "Tres hombres", publicado também em 1960, foca a figura do "matrero" Velasco dos anos 1870; "Un cuento con um pozo", publicado em 1969, mostra a difícil decisão de Martiniano Ríos de se esconder no poço porque não quer participar de mais uma guerra de Fronteira; "La escoba de la bruja", publicado em 1979, evidencia os costumes, as superstições, o código de honra do homem do campo por volta de 1870.

No entanto ao contrário da "gauchesca decorativa" que maneja o passado com vistas ideológicas no presente, sua literatura não vai revisitar o "antes”, para legitimar o "status quo" do momento da escrita. Arregui, nesse modo muito particular, revisita o contexto das guerras civis do Uruguai para demonstrar que a mesma arbitrariedade do passado muda de forma e de mãos, mas continua intacta em sua essência: "domar" a vida do "gaucho", por meio de uma relação de poder perversa que o impede de visualizar de onde provém sua exclusão.

Nesses contos, há a presença de uma voz que se manifesta na primeira pessoa do plural, cuja intenção é demonstrar que, não obstante afastada daquele contexto histórico e daquela realidade, sente que tudo aquilo faz parte de sua vida e determina o presente. Além disso, é uma técnica que visa cativar a atenção do leitor para que mergulhe no mundo narrado. É certamente a voz de Mario Arregui que, em alguns momentos, interrompe a trama para incorporar a ela observações, colocadas em sua maioria entre parênteses. São segmentos explicativos para evidenciar a sua erudição e o seu 
conhecimento de uma literatura universal. Essa técnica, além de romper com o "canón realista", visa demonstrar a universalidade desses contos.

Mas esses "parênteses" nem sempre demarcam o erudito. Muitos são colocados para evidenciar os provérbios "gauchos". Portanto, numa relação de oposição e complementariedade, os trechos entre parênteses não são inseridos apenas para demonstrar um Arregui preocupado com o culto, com o universal, mas também evidenciam um Arregui que vê a necessidade da retomada do universo campeiro, "gaucho", complementar à identidade desse escritor que transita entre a vanguarda e a tradição pratina.

Já, em muitos contos fronteiriços de Sergio Faraco, o tempo não é demarcado com clareza. Há precisão do índice temporal somente no conto "O vôo da garça pequena", cuja ação se passa em meados dos anos 50, como abordado. Como em "Travessia" e "Guapear com frangos", "O vôo da garça pequena” põe em cena a personagem López; assim conclui-se que estes contos também se passam nessa época.

Quando o enredo se localiza num tempo um pouco mais distante em relação ao momento da escrita, há a visão de uma realidade menos árida da vida dos gaúchos, como no conto "Lá no Campo", e "Velhos". Nesses contos, os personagens são capatazes de estância e uma relação amistosa entre eles e os estancieiros é colocada em cena, embora a hierarquia seja plenamente demarcada. "Aventura na sombra" também narra a história de um menino de estância que faz de sua égua, sua primeira fêmea. Em "Dois Guaxos", "Manilha de espadas", "Noite de Matar um homem”, "A voz do coração", "Bugio amarelo", “Adeus aos passarinhos", "Hombre” tomaremos contato com uma realidade do homem que vive na miséria. A periferia das cidadezinhas de fronteira e o contrabando de mercadorias por meio de chalanas são colocadas em cena. São narrativas cujo tempo da ação aproxima-se do momento da escrita; assim quanto mais o índice temporal dos contos aproxima-se do presente, mais violenta torna-se a vida desse homem.

Também, nos contos de Faraco, uma voz sutil, de quem conta um caso, mistura-se à narração em $3^{a}$ pessoa e se deixa ouvir. Ela está presente em alguns momentos do conto "Manilha de espadas", "Guapear com frangos". Esses contos são desfiados por um narrador em $3^{a}$ pessoa, não distanciado da realidade apreendida, uma vez que consegue aproximar-se do universo da Fronteira. Pelo seu discurso, são ressaltados os hábitos, os 
costumes. Além disso, assume o linguajar daqueles homens, que misturam léxicos que pertencem a um e outro lado. Porém esse narrador, que se manifesta com certa imparcialidade cede lugar a uma voz que se intromete na narração para estabelecer sua opinião. Há, portanto, uma voz que se manifesta em $3^{a}$ pessoa para narrar a ação; mas, em alguns momentos, ela tem total controle sobre a narrativa, pois conhece bem a realidade que apreende e, por isso, pode se intrometer para ressaltar o que deseja.

Essa voz, diferentemente do que ocorre nos contos de Arregui, não é a do autor culto. Possivelmente é a do menino-narrador do conto "Travessia". Todos os contos em que ele é o protagonista são narrados em $1^{a}$ pessoa, mas aqueles em que não participa diretamente da ação são colocados em $3^{a}$ pessoa. Esses, por sua vez, na sua maioria, envolvem as aventuras de um certo López, que evidentemente, é Joca López, o tio que o menino tanto admira.

Por admirar, o narrador sempre coloca Joca López, apesar de ser contrabandista, na posição de um herói que acumula as características de valente, leal, bravo, altivo. Logo, os contos que são narrados em $3^{a}$ pessoa, dentro de um contexto específico, vão oferecer uma visão que aproxima o gaúcho atual das cidades fronteiriças ao gaúcho-herói, colocado em pé pela literatura das primeiras décadas de 1900. Afinal, os "casos" desfiados devem "calar fundo ao coração" e falar de "homens que tenían algo más que leche en los cojones."

E, se são casos de exagerada coragem, ao contrário dos contos de Arregui, eles têm o porquê de ser, uma vez que são contados por um narrador-gaúcho, homem da fronteira, cuja memória é impregnada pelas histórias do passado, que moldaram sua identidade como herói. Impressionante como Faraco ficcionaliza e problematiza, por meio da voz de um narrador, toda essa discussão ideológica a respeito da formação da identidade cultural do gaúcho-herói, construída por literatos e historiadores.

Facetas da região da Fronteira, da Campanha, que compõem uma identidade, forjada sob ideologias, resistências, pedidos de ajuda, vêm à tona, por meio do narrador.

Sintoma de que Faraco põe em discussão, por meio da voz narrativa, as características do regionalismo das primeiras décadas do século $X X$, é o uso de descritivismo da paisagem rural em alguns contos, como em "Lá no Campo". Mas ao mesmo tempo que se utiliza da técnica das "manchas" descritivas, ressalta que a democracia rural é mito. Na verdade, é estabelecida a visão de que peões e patrões entendem-se, mas a pregada igualdade é questionável, porque a hierarquia entre eles 
deve ser conservada, como atestado no conto "Velhos", embora os mais "novos", como Neco, também desejem romper esse obstáculo.

Essa ambientação rural, ainda privilegiada, cede lugar ao cotidiano dos habitantes que compõe "os cinturões de miséria" das periferias das cidades da Fronteira. Se Cyro Martins, em sua obra, evidencia que o destino dos gaúchos expulsos do campo é a periferia dos acanhados centros urbanos da Região da Campanha, Faraco expressa, como numa espécie de continuidade à obra de Cyro, a sobrevivência dessa população que, além de estar "a pé", nem sequer lembra que um dia já teve cavalo.

Esses contos que abordam esse dia-a-dia de misérias, de contrabando, são narrados em $1^{a}$ pessoa, por um protagonista que no conto "Travessia" (1974) é ainda um menino, mas nos próximos, "Noite de Matar um Homem" (1986), "A voz do coração"(1984), "Bugio Amarelo" (1978), "Adeus aos passarinhos" (1986), "Hombre" (1978), torna-se homem e continua naquela vida de contrabando. personagem-narrador sofre toda uma transformação (como acontece com o Rio Grande do Sul?), já que de menino sonhador, ele se transforma num contrabandista-assassino, que mata em busca do lucro individual.

Embora a vida ilegal impere, os contos possuem cunho social e reivindicatório, porque o que ecoa, como em Martín Fierro, de Hernández, é a voz do gaúcho marginalizado. E se ele conhece sua realidade de opressões, mas não sabe como transformá-la, surge a voz do escritor, de Sergio Faraco, que sempre "visa a salvar alguém de algo", como abordado no conto "Sesmarias do Urutau Mugidor", para dar luz ao viver dessa população esquecida. Afinal, como já dito por Erico Verissimo, "se não tivermos uma lâmpada elétrica, acendamos o nosso toco de vela, ou, em último caso, risquemos fósforos repetidamente, como um sinal de que não desertamos nosso posto", para clarear o cotidiano de injustiças e atrocidades que marcam a vida dessa população.

E num cenário, que se alterna entre a vida do campo, onde os costumes ainda estão vivos, e a vida de contrabando e bandistimo das periferias das cidades de fronteira, move-se o "gaúcho" de Faraco. Um herói, que a seu modo, consegue manter a honra, a altivez a hombridade, mas que, inúmeras vezes, revela sua face de covarde, de ambicioso, uma vez que o lucro está em primeiro lugar. O que ganha a cena é seu traço humano, nem de herói, nem de anti-herói, apenas humano, que "odeia" tudo aquilo que não compreende. 
E o ser odiado é o outro que não mantém o código de honra gaúcho, baseado na valentia e lealdade, embora nem mesmo aquele que prima por esse código possa sustentá-lo, como o caso do personagem-narrador do conto "O Bugio Amarelo". Sintoma de que o imaginário do "gaúcho-herói" ainda existe, embora em agonia, porque não pode ser mantido.

O ser odiado é também a lei e os estancieiros de um lado e do outro que dominam a região e impedem que o homem das periferias da cidade de fronteira consiga tirar do contrabando o seu sustento. Maneira ilícita de ganhar a vida, abordada pela literatura, como um pedido de ajuda frente ao cotidiano de violências que se naturaliza.

Mas na literatura de Faraco e Arregui não há a banalização dessa miséria. Haverá a lembrança de que o gaúcho foi expulso do campo e, frente à vida nas cidades de fronteira, torna-se um contrabandista ou, como também demonstra o conto "Los ladrones" de Arregui, pode se tornar um "fora da lei" em busca de suas necessidades. É um homem que não se adaptou à nova ordem da Industrialização, o que o jogou à "margem do rio", cenário dos muitos contos fronteiriços de Faraco. A miséria, todavia, é cultural e, por isso, mutável, constatação que o leitor erudito lê nas entrelinhas das narrativas desses dois escritores.

Assim como Arregui, Faraco começa a escrever seus contos num momento de crise. Nos anos 70, o Brasil encontra-se, mediante a imposição da Ditadura militar e da entrada do capital estrangeiro, e grandes transformações começam a se delinear, o que vai desembocar no que modernamente chamamos de globalização. Frente a esse processo, Faraco escreve para evidenciar as mazelas trazidas por ele, como a exclusão e a busca pelo lucro que se acirra.

Observa-se também que muitas narrativas retomam costumes e tradições sempre vivenciadas pelos gaúchos, como tomar chimarrão, tal qual os contos de Arregui. Isso soa como uma resistência à homogeneização dos comportamentos que começa a se impor frente à internacionalização do capital. "Já não se trata de nostalgia, mas da aceitação de um estilo de vida diferente, que ainda não desapareceu de todo, e no qual há espaço para a crítica das evidentes desigualdades."

Faraco e Arregui, por meio de técnicas diferentes falam para outros gaúchos e "gauchos", mas, sobretudo, para o público letrado; por falar em prol do homem que vive "à margem do rio", interpretando e favorecendo seu desenvolvimento histórico; por não atuar a serviço de um grupo social distinto, mediante formas persuasivas de literatura 
que escamoteiam a realidade; por escrever uma literatura de cunho social, são escritores gauchescos num sentido amplo.

Segundo Pablo Rocca, podemos considerar que Sergio Faraco e Mario Arregui fazem parte de uma geração de escritores denominados pós-gauchescos, já que admitem e reconhecem o caráter sucessor da gauchesca, mas reajustam e modernizam os meios expressivos desse tipo de literatura de acordo com as transformações econômicas, políticas, sociais e estéticas.

A literatura desses dois autores, ao contrário dos regionalistas brasileiros e dos "criollistas" uruguaios dos anos 1920, não servirá a uma classe dominante, nem seus contos estarão condenados ao "beco" por localizarem sua ação numa região específica, a comarca pampeana.

O desafio desses escritores é "possibilitar que a condição de fronteira construa algo que tenha valor para ser compreendido/lido/apropriado por outros que não os próprios que a vivenciam; é "romper com o local/regional , para perder a territorialidade que foi o início da ancoragem do conceito de fronteiras e chegar a uma terceira dimensão".

Enfrentam, então, o problema de outros regionalistas: fazer, no caso, o "gaucho" e o gaúcho falar, "tornando verossímil a fala do outro de classe e de cultura para um público citadino e preconceituoso que, somente por meio da arte, poderá entender o diferente como eminentemente outro e, ao mesmo tempo, respeitá-lo com um mesmo: 'homem humano"'

E Arregui, ligado à geração de 45 do Uruguai, considerou autêntico não ceder a voz ao homem pobre do campo, embora cite inúmeros provérbios "gauchos", ao contrário de Faraco que interiorizou a voz do gaúcho, técnica que possivelmente buscou no Martín Fierro ou nas técnicas de João Simões Lopes Neto, escritor que deu voz ao velho Blau "numa fala recuperada e construída literariamente"; além disso, Faraco dá voz a esse homem por meio do uso da linguagem híbrida, ou seja, da mistura do português com o espanhol; da estruturação sintática que se acomoda à fusão da fala do narrador com a do personagem. Ambos "tornarão audível a voz desse homem (...)ao leitor da cidade , de onde surge e para a qual se destina essa literatura".

Dentro desse contexto, Sergio Faraco e Mario Arregui são escritores regionalistas num sentido amplo; são escritores universais, porque "por menor que seja a região abordada, por mais provinciana que seja a vida nela, haverá grandeza, o espaço se 
alargará no mundo e no tempo finito na eternidade, porque o beco se transfigurará no belo e o belo se exprimirá no beco" , o que demonstra que os seus contos que tratam desse homem fronteiriço não são e nem nunca serão mera ilustração dos conflitos regionais.

Esses autores trabalham com uma intenção fundamentalmente artística, embora não deixem de contribuir ocasionalmente para propósitos políticos ou sociais reivindicatórios, no sentido de lutarem, por meio da letra, contra a exclusão trazida pela modernização. Enfim, os contos de Faraco e de Arregui que falam da região da fronteira entre Brasil - Uruguai -Argentina apresentam uma elevação estética que não requer ruptura nem anulação do gauchismo (e do regionalismo) mas transformação e abertura do que já foi adquirido.

Nesse sentido, incorporam, em seus textos, a cor local, por meio da criação de uma linguagem peculiar, que resgata o modo de expressão regional e que estabelece um diálogo entre a tradição popular e a erudita, numa busca de identidade que transcende fronteiras, porque essa é pensada como "algo novo, algo que vai além", o que significa "estabelecer um pensamento "sem fronteiras"”.

Apesar de técnicas diferentes, a literatura de Faraco e Arregui evidencia que a integração entre o homem "do lado de cá" e o "do lado de lá" existe e se manifesta em forma de uma cultura comum aos dois lados. Evidencia que trechos do Brasil, Uruguai e Argentina são "irmanados".

Mas a figura que habitou "a comarca pampeana" e muito acrescentou à cultura rio-grandense, uruguaia e argentina, longe de ser um herói é um pobre homem e um homem pobre. Assim, o "gaucho" e o gaúcho, como evidencia a literatura desses dois escritores, ainda existem sob uma nova capa, sob novas formas de realidade, a serem desvendadas pela letra, "que transcende as fronteiras nacionais e as barreiras lingüísticas”.

\section{APÊNDICE I-Resumo dos contos}

\section{1- Contos de Mario Arregui}

\section{Un cuento de fogón}

Nicodemo Carrión, tropeiro de profissão, passa a noite bebendo e jogando truco. Ao amanhecer, quando decide ir embora, percebe que os seus cavalos haviam 
sumido. Ao não ter sucesso na sua busca pelos animais desaparecidos, resolve consultar uma curandeira e adivinha, Dona Viviana, para ter conhecimento do rumo dos cavalos. No final do conto, o tropeiro encontra seus cavalos exatamente no lugar indicado pela vidente.

\section{"Contaba Don Claudio"}

"Contaba Don Claudio", além de conter os "relatos" desse "genuino criollo", possui, no início, uma espécie de ensaio, onde Arregui retoma suas observações a respeito do embrião da contística uruguaia, que, segundo ele, nasceu "en los fogones gauchos".

Os casos de Don Claudio são exagerados, pois ele contava a história sobre estâncias onde tudo era gigantesco e os aviões passavam entre os fios das cercas; casos sobre sua faca que de tão afiada não cortou somente o assado, mas também o prato, a mesa e até um pobre gato que passava por debaixo dela. As guerras contagiam sua memória, mas ele endossa a valentia do "gaucho-héroe" de maneira mais equilibrada. Para ele, os índios não deixam de ser sanguinários; porém os seus relatos que envolvem arborígenes nunca acabam em sangue.

\section{"El caballo piadoso"}

Macarrón García, protagonista do "El caballo piadoso", é um homem nascido no Uruguai, que comporta certas características do "gaucho" dos primórdios, já que gosta de beber, é um pouco briguento, um tanto mentiroso, desconfiado e, sobretudo, mulherengo. Ele é um minifundista e vive à margem do Rio Negro, em companhia de um velho peão e uma negra. Em uma ocasião, apesar de ter chovido muito, Macarrón decide encilhar seu cavalo para ir atrás de uma aventura amorosa. O arroio ou riacho, que deveria atravessar para prosseguir seu caminho, estava demasiado cheio. Mas mesmo assim, decide atravessá-lo com seu cavalo, que, na metade da travessia, começa a se cansar. Mancarrón percebe que está afundando e começa a rezar. O desfecho é tragicômico: o cavalo, que havia sido de um cura e era católico, ao escutar a melodia da "oração", ajoelhou-se. A força da água tomou por surpresa o "semi-héroe", que se afogou. 


\section{"Noche de San Juan"}

Francisco Reyles retorna ao "pago", após muitos dias de uma longa viagem com suas tropas. Depois de rever os amigos, decide ir às ruas dos prostíbulos. Quando sai de uma dessas casas, por volta da meia-noite, sente que sua solidão, ao invés de desaparecer, apenas aumenta. Reyles não é mais o "gaucho" dos campos livres, sem cerca, mas aquele que sofre com a transformação do Pampa, com sua vida de tropeadas, sem muito sentido, porque é um ser em busca de algo que não se resume mais à doma, ao sexo, ao alcóol. Encontra-se, então, com uma prostituta e se dirige ao quarto dela. Não deseja sexo, mas a companhia dela, o que o leva a abraçá-la. Levanta-se e vai embora. Pisa nas cinzas que sobraram da fogueira, a que, no início da noite, havia lançado folhas secas para fazer o fogo crescer. Ao aparecerem brasas, esmaga-as rancorosamente.

\section{“El regresso de Odiseo González"}

"El regresso de Odiseo González" conta a saga de Ranulfo que, após se fingir de morto para ter a vida poupada na guerra de fronteira de 1820 , chega muito machucado à estância de um vasco que lhe dá abrigo. Lá permanece e resolve regressar ao seu lar mais dois anos depois da manhã que havia saído para a guerra e fora machucado. Quando regressa, sua mulher tem outro. No entanto, ela opta por ele, pai de seus filhos, e tudo voltou a ser como era antes da guerra.

\section{"Los Contrabandistas"}

Este conto põe em cena o cotidiano de Ranulfo Alves, o chefe dos contrabandistas, que juntamente com os seus homens, grupo em que se destacam os irmãos Juan e Pedro Correa, cruzam o rio Jaguarão, que demarca a fronteira entre Jaguarão, no sul do Brasil, e Rio Branco, no Uruguai, para executar o contrabando de mercadorias. Numa dessas travessias, quando se aproximavam da margem uruguaia, são surpreendidos pelas patrulhas fronteiriças que atiram contra eles. Os irmãos conseguem alcançar a margem brasileira. Ali, Rulfo é encontrado muito machucado. Os Correa tentam levá-lo até um português curandeiro. No entanto, Rulfo Alves, montado em uma mula, puxada pelos irmãos, tem delírios durante o caminho e começa a conversar 
com os mortos, inclusive com aqueles que já havia assassinado. Juan e Pedro contagiam-se pelos seus dizeres. Para não enlouquecer, Pedro acaba por matar o chefe dos contrabandistas.

\section{"Tres hombres"}

Ramiro Pazos desempenhava a profissão de comissário, numa vasta região rural. O lugar que Pazos governa é composto por vários ranchos de diversos tamanhos e é denominado "comisaría'e Pazos", o que demonstra o poder que detém. Pazos recebe a visita de dois estancieiros fortes da zona, avisando-o que Velasco andava pelo lugar. $\mathrm{O}$ comissário e o sargento Maciel saem em busca do "fora da lei". Quase depois de três dias de busca infrutíferas, Maciel consegue informações sobre Velasco. Ao longe, Maciel localiza o " "matrero", que se embrenha numa mata próxima para onde Maciel se dirige. Ambos desaparecem. Pazos não consegue alcançá-los. Desiste da empreita e, como Maciel não retorna, resolve pernoitar numa estância de um inglês, localizada próxima do local onde se encontrava. No dia seguinte, Pazos encontra com Maciel, que havia prendido Velasco ali perto depois de uma "peleia". Finalmente, os "tres hombres" do relato se reúnem. Pazos que visa submeter Velasco e, ao perceber que não é ele quem merece o mérito da prisão, começa a golpeá-lo. Maciel solidariza-se com a situação do prisioneiro, arranca a arma do comissário e solta o "matrero". Então, o sargento afasta-se da cena do duelo e se senta à beira de um lago. Instantes depois, escuta passos que se aproximam. Vê, na água, o reflexo de Velasco que Ihe diz: "- A sus ordenes, Sargento".

\section{"Un cuento con un pozo"}

Martiniano Ríos, num alvorecer, tem sua tranqüilidade quebrada pelo desasossego de seu cachorro. Martiniano percebe que a intranqüilidade do cão só poderia ser o presságio de algo ruim. Lembrou-se então de que ouvira falar na "pulpería", perto da estância onde morava, da possibilidade de uma nova guerra civil. Avista ao longe mais de cinqüenta ginetes que se aproximavam. Então, dirige-se ao rancho, acorda sua esposa Josefa e the diz que estava vindo outra guerra. Já que conhecia a situação difícil de ser arregimentado para uma guerra, pois já havia servido em duas, e ao acreditar que a função daquela patrulha era procurar soldados para um próximo embate, Martiniano fica desesperado. Decide, apesar da objeção de Josefa que não esperava isso dele, 
esconder-se no poço. Martiniano, no fundo do poço, entra num estado de embriaguez, em virtude da falta de oxigênio. Acorda com o ruído do balde, prezo à corda, que descia batendo na parede. Teve a quase certeza de que Josefa o jogara para dentro. Sobe com dificuldade. Pouco antes de chegar ao rancho, tropeça no corpo do cachorro, degolado. Ao entrar, vê Josefa e compreendeque havia sido violentada por muitos homens. O filho estava no catre conjugal, encolhido, o rosto oculto entre os braços, chorando baixinho; havia sido castrado. Martiniano desce novamente ao fundo do poço e se suicida com um tiro do seu revólver.

\section{"Diego Alonso"}

Diego Alonso, protagonista do conto, vai a uma Barbearia do seu bairro. Chegando lá, o barbeiro o acusa de estar dormindo com uma certa mulher. Alonso não entende a acusação, pois responde que aquela mulher não dizia respeito ao barbeiro. Mas este não se contém e o ameaça com um punhal. Ao perceber que está desarmado, Alonso foge. Quando chega em casa, embora com as mãos trêmulas, coloca sua faca na cintura e volta à barbearia. Pede, então, para que sua barba seja feita. Toda a tensão da cena é descrita minuciosamente, pois a navalha afiada do seu adversário passa duas vezes por toda sua face. No final, deposita no balcão as moedas pelo serviço e sai tranqüilamente na certeza de que a raiz de onde nascia sua coragem continuava intacta.

\section{"Un cuento con insectos"}

O conto se inicia com a descrição da sala de jantar da estância "La alborada" de Don Marcial Lopes, que recebe a visita de Pedro Arzábal, capataz da estância vizinha. Pedro fora à estancia "La alborada" conversar sobre o gado e outras coisas com Don Marcial e, como já começava a anoitecer, aceita o convite do dono da casa para pernoitar ali. Na sala também se encontram Dona Leonor, esposa de Don Marcial, e o filho do casal, a que chamavam Marcial chico. Quem vem jantar, e se juntar aos quatro personagens, porém sem dizer uma palavra, é niña Leonor, a primogênita do casal, considerada uma lunática por muitos. Pedro imediatamente sente um desejo louco por aquela mulher enigmática que deixa a sala de jantar sem dizer nada. Os homens, depois da saída de niña Leonor, mantêm o diálogo por mais algum tempo. Em seguida, Marcial 
chico conduz Pedro ao quarto de hóspede, meio afastado da casa da estância. No pátio, os dois vêem e escutam niña Leonor uivar como uma vaca. Marcial justifica-se dizendo que a irmã está meio louca e ficava pior em noites como aquela de lua cheia. Depois de algum tempo, niña Leonor bate à porta e, sem dizer palavra, deita-se com Pedro; depois, foge às pressas. Quando já amanhecia, Pedro escuta novamente batidas na porta e a abre. Niña Leonor entra, e Arzábal vê, na mão da moça, o revólver dele, o qual deixara sobre a cômoda e de cuja subtração não se apercebera. Pedro tenta desarmá-la, mas ela começa a atirar e o mata.

\section{"La escoba de la bruja"}

"La escoba de la bruja" traz o caso de um duelo de facas, cujo motivo não é esclarecido, entre o tropeiro Miguel Yuste e um tratador e variador conhecido por Paredes por volta de 1870. O duelo é assistido pelos três filhos de Yuste, que é ferido de morte por seu adversário. Os dois filhos mais velhos tentam perseguir Paredes para matá-lo também, porém o irmão mais novo, Juan Pablo Yuste, impede-os. Paredes depois de vencer o duelo, desaparece do "pago". Algum tempo após o velório de Miguel Yuste, os seus dois filhos mais velhos viajam com tropa e não voltam mais. Somente ali permanece Juan Pablo. Este toma conhecimento de que o assassino de seu pai, trinta e tantos anos depois do duelo, estava de volta ao pago, já muito velho e debilitado. Paredes instala-se numa estância cujo capataz era um de seus irmãos. Falece pouco tempo depois, e seu velório acontece no galpão do lugar onde viveu seus últimos dias. Então, o inusitado acontece: Juan Pablo chega ao velório, dirige-se ao fundo do galpão e, apesar dos muitos protestos, toma o cadáver e parte a galope com o corpo inerte de Paredes dobrado sobre o cavalo. Juan Pablo enterra Paredes ao lado de Yuste, o que pode ser comprovado pela existência da terra removida e pela aparição de mais uma cruz de madeira muito junto à cruz do pai de Juan.

\section{"Los ladrones"}

"Los ladrones" narra um acontecimento na vida de Mariano Gómez e Alejandro Rodríguez, muito amigos e aspirantes a ladrões. Eles resolvem roubar o italiano Orsi, o padeiro solitário e avarento daquele bairro mais miserável da cidade. Esperaram a noite 
chegar e se dirigiram para o galpão onde o padeiro trabalhava. Ficam espiando Orsi pela janela. Porém, ao observarem todo o labor do padeiro, são surpreendidos pelo inusitado: Orsi, depois de encher os cestos de pães que seriam vendidos no dia seguinte, com uma porção grande de massa, começa a sová-la sobre a mesa e esculpe nela o formato de uma mulher. Depois, deita-se sobre a mulher-pão. Ao perceberem a situação, Mariano e Alejandro sentiram que continuar ali seria um ultraje algo ou a alguém. Numa atitude de respeito ao outro, os fracassados aspirantes a ladrões retiraram-se da janela.

\section{2- Contos de Sergio Faraco}

\section{“Lá no campo"}

O velho Cuertino López e seu filho Joca dirigem-se a um velório do sogro de Vicente, capataz da estância vizinha. A ação desses dois personagens fica paralisada para o enredo colocar em evidência o ambiente campeiro, os costumes dos gaúchos, como tomar chimarrão. O Doutor Romualdo, dono da estância, é colocado brevemente em cena. Após conversarem com esse estancieiro, Vicente e Cuertino concordam que ele é um homem bom, num contexto onde peões e patrões entendem-se, porém fica bem demarcada a hierarquia entre eles. Há ainda o destaque a outros costumes, como começar um "bom velório" com uma roda de truco. Essa narrativa constitui simples "recuerdos de gente velha", como afirma Cuertino, mas, certamente, esses recuerdos têm contagiado os mais novos.

\section{"Aventura na sombra"}

O enredo resume-se à aventura de um guri que faz de sua égua, Flor-de-lis, sua primeira "fêmea". A descrição privilegiada da paisagem rural abre "Aventura na sombra". Com a desculpa de ir até o Bororé, o povoado mais próximo da estância onde reside, o menino pára no meio do caminho e "com gestos rápidos, nervosos, maneia a égua e a empurra de ré contra o alambrado. Sobe no terceiro fio e se deita sobre suas ancas." O narrador em $3^{a}$ pessoa conhece muito bem o universo daquele guri do campo e suas intenções, pois descreve de forma erotizada a paisagem, que se mistura às apreensões do menino que se faz homem num ambiente de estância. 


\section{"Dois Guaxos"}

Esse conto traz à tona a miséria de um menino, Maninho que presencia sua irmã, Aninha, de dezessete anos, entregar-se ao Cacho, um índio velho que viera do Bororé para ajudar na lida diária. Sua irmã, depois da morte da mãe, era quem cozinhava, remendava o "trapeiro" e ensinava-Ihe a ler umas poucas palavrinhas. Mas, Maninho, amargurado, pressentia que ela iria virar "mulher da vida". O pai não se dava conta da miséria física e psicológica que ameaçava os filhos. Assim, o menino resolve partir daquela "chacrinha". É o desamparo que o leva a montar no seu cavalo e se atirar no mundo. Resolvera que iria para Itaqui. "Depois ia cruzar o Rio Uruguai, ou não cruzar, ou ia para Uruguaiana, Alegrete, ou para a Barra, Bella Union, lugares dos quais ouvira um dia alguém falar." E, um dia, quem sabe voltaria para seu pago.

\section{"Manilha de espadas"}

No início do conto, há a descrição do cotidiano de um pequeno povoado próximo às cidades da fronteira. $\mathrm{O}$ forasteiro, que viera parar naquele vilarejo e se hospedara na pensão de Pepeu Gonzaga, é convidado a jogar truco; porém é roubado pelo dono da pensão e pelos seus comparsas, Comissário Boaventura e o mulato Isidoro, cabo da Brigada e chefe do destacamento local. Quando o jogo acaba e todos se recolhem para dormir, o forasteiro mata o dono da pensão e foge com o dinheiro. Porém esse assassinato não é colocado no conto como um imprevisto, uma vez que, logo após o jogo, o forasteiro vai se deitar num quarto onde há um guri que o chama de tio. O menino aguarda as ordens do homem, pois também "se deitara sem tirar as alpargatas. Decerto revivendo outras madrugadas de um mesmo ritual." Assim, espera o "tio" "pegar o dinheiro" e rumam para "a fronteira, para o rio, caminhada de uma hora quando muito."

\section{"Travessia"}

Joca, personagem principal de "Travessia", é um contrabandista. Sua rotina é atravessar mercadorias de Itaqui, cidade fronteiriça do Rio Grande do Sul, rumo ao Alvear, vilarejo localizado na outra margem do rio Uruguai já pertencente à Argentina. Num dia de muita chuva, ele e seu sobrinho, ainda um menino, resolvem atravessar o rio, pois sabem que, 
em dias de tempestade, a possibilidade de passar despercebidos pela patrulha dos fuzileiros brasileiros, que controlavam o movimento, era maior. Mas aquela travessia complica-se. Primeiro, há a força do rio, domada por Joca; depois, surge a força da lei. Ao perceber que os fuzileiros do Brasil aproximam-se, Joca joga todos os produtos na água. Quando os holofotes do barco dos policiais acendem-se para iluminar o de Joca, ele afirma que tinha peixes ali, mostrando o cesto de cascudos que trazia justamente para uma situação desse tipo. É obvio que a autoridade duvida, todavia não pode fazer nada, pois não há prova de contrabando. O conto se fecha com Joca, "teso e imóvel", olhando para a sombra densa do rio, vigiando o trajeto da chalana vazia.

\section{"Noite de matar um homem"}

Esse conto, como o anterior, "Travessia", é narrado em $1^{\text {a }}$ pessoa. 0 narrador-protagonista e seu companheiro, Pacho, são contrabandistas e resolvem assassinar Nassico Feijó, a quem chamavam Mouro. O motivo do crime se resume ao fato de o Mouro estar atrapalhando seus "negócios". Quando finalmente encontram o inimigo, retrocedem por não terem coragem de executar o plano. No caminho de volta, deparam-se novamente com o Mouro. É, então, no susto, que Pacho atira e derruba o outro que cai morto com os olhos esbugalhados. Pacho senta-se no chão, abraça a vinchester e chora como uma criança. Enquanto o narrador, frente à cena do assassinato, vomita. Quando voltam para casa, o Tio, que havia mandado os dois jovens para aquela missão, pergunta sobre a "viagem". O narrador conclui que não adiantava falar o que sentia, recobra sua altivez e responde que o caminho estava livre para as "travessias" dos produtos contrabandeados.

\section{"Guapear com frangos"}

Nesse conto, López promete transportar o corpo do tropeiro Guido Sarasua, encontrado já em decomposição no rio, uma vez que havia se afogado por se aventurar "à louca travessia" num momento em que a correnteza se sobrepunha às forças humanas. Ao amarrar o corpo, que já apodrecia, a uma forquilha e ao prendê-lo em seu cavalo, sente que a missão de levar o cadáver até a sua família não seria nada fácil, apesar de não aceitar sua fraqueza. Apesar dos cuidados de López, o corpo inerte de Guido Sarasua é devorado por bichos durante o cortejo. Ao ter que lutar contra os corvos 
e seus inesperados vômitos, López desmaia. Quando acorda, presencia um banquete de aves que "atracavam na carniça" do pobre tropeiro. E, num lance surreal, ele se atraca com um dos corvos, mas não consegue matá-lo. Então, aproxima-se do corpo estraçalhado e, para impedir que o resto seja devorado, abre, com uma faca, o osso do peito de Sarasua ao meio.

\section{"A voz do coração"}

A abertura do conto traz o cenário da fuga do narrador-protagonista, de Pacho e de Maidana que querem alcançar o Inhanduí, afluente da margem esquerda do Rio Ibirapuitã, no município de Alegrete. Eles tentam escapar dos homens de Orlando Faria, que perseguem os três em virtude de eles fazerem furtos na propriedade, roubando, por exemplo, penas de avestruz. O estancieiro Orlando Faria, o Gordo, é qualificado pelo narrador-personagem como "endemoniado" e "sem coração". Apesar de sua condição de bandido, o protagonista reconhece que o Gordo é diferente dele, porque cometia atos ilícitos não para garantir sua sobrevivência, mas em nome do acúmulo de bens materiais. Madaina, ao não querer prosseguir, é apanhado e morto pelo grupo que perseguia os três. Já do outro lado do rio, ao ver um capanga do Gordo, o protagonista ergue seu revólver e atira. O adversário cai de bruços entre as patas do cavalo. E, "como dois bichos, andando de quatro" os dois personagens se distanciam ouvindo os gritos do moribundo e, "de repente não se ouviu mais nada" e, então, voltam a caminhar.

\section{"O vôo da garça-pequena"}

López, um contrabandista, promete trazer para Maria Rita, prostituta nova de o "La Garza", casa de mulheres do Alvear, vilarejo do outro lado do rio, um Philco vermelho de três ondas. Maria Rita era nova naquele lugar que López costumava freqüentar. Vinda de Maçambará, cidade do Rio Grande do Sul, tinha deixado o marido, que a surrava, para fazer a vida. Cocona, uma velha paraguaia e dona da casa, explicou a López que era uma mulher "metida a idéias". Maria Rita interessa-se por López, quando Cocona lhe diz que ele era o "homem dos rádios" trazidos de Uruguaiana. Para conseguir o rádio, Maria Rita aceita se deitar com López. Começam a conversar e Maria Rita Ihe diz que ouviu dizer que em Uruguaiana, em Itaqui ou em São Borja, não sabia ao certo, havia uma mulher doutora, que trabalhava no hospital. E para saber do que se 
passava pelo mundo, em Porto Alegre, para ter idéias é que queria o rádio. Finalmente, quando aquela mulher "cheia de idéias" o convida para deitar, ele se levanta e vai embora, porém promete o rádio a Maria Rita e diz que ela não precisará pagar nada por ele. O conto se fecha com a descrição da debandada dos bichos que estranhavam a passagem de López, no caminho de volta para o barco. Entre eles, havia a garça-pequena "com seu véu de noiva, suas plumas alvíssimas", e o narrador conclui: "López talvez a tenha visto. Ou talvez não."

\section{“Bugio Amarelo"}

Nesse conto, o narrador-personagem, pernoita no quintal da casa de seu amigo Amâncio, que fora a Monte Caseros, Argentina, para comprar duzentas caixas de balas incendiárias, com venda certa para lavoureiros da região, por causa das caturras.Como se sabe ainda hoje é comum nas zonas fronteiriças do Rio Grande do Sul, em pequenas propriedades com lavouras, o emprego dessa espécie de munição para destruir ninhos de caturras no alto dos eucaliptos. As balas incendiárias, cuja venda é proibida no Brasil, são contrabandeadas da Argentina.

Amâncio antes de subir o rio nessa empreitada, pede ao personagem-narrador para zelar pelo bebê que estava doente. Na casa, também dormia Zélia, esposa de Amâncio. De repente, o protagonista ouve seu amigo Bagre chegar ao pátio e lhe dizer que tinha "bugio no bananal do Amâncio." Bagre se referia ao alemão da pulperia que tinha entrado na casa do amigo para ficar com Zélia. Decide, então, entrar na casa e surpreender os dois. Consegue surrar o Bugio amarelo, mas também é surrado por ele. No entanto, o alemão foge, enquanto ele permanece sozinho com Zélia que o seduz em troca do seu silêncio. Todavia, ao sair da casa, pede para o Bugre não comentar nada para ninguém sobre Zélia e o Bugio. Decide, então, ir embora da cidade, ato que funciona como uma espécie de purgação diante da traição cometida. Encontra Amâncio e lhe dá um longo abraço. Antes de sua partida, mata o alemão.

\section{"Adeus aos passarinhos"}

Esse conto evidencia as divagações de um "eu" que abandona a sua terra. Essa narrativa mostra toda a angústia dessa decisão por uma espécie de monólogo interior. Nas constantes memórias do narrador, aparece um menino dos "velhos tempos" 
cheio de vida que se confronta com o que ele se tornou: "um monstro", um zumbi, meio vivo, meio morto. Há uma sensação de não pertencer ao "mar" a que foi jogado, uma impressão de falta de um lugar para que lhe conceda a condição de "ser", pois sente um nítido estrangulamento frente àquela vastidão. E o passar do tempo simplesmente zune dentro dele como um inseto "sem rumo".

\section{"Sesmarias do urutau mugidor"}

A narração em primeira pessoa traz a voz de um escritor de Porto Alegre que está de mudança para Uruguaiana. No caminho, desvia-se de sua trajetória e, depois de muita chuva, tem problemas com o seu carro. Pede, então, abrigo a um velho gaúcho que mora com sua filha à beira da estradinha em um rancho pobre. O velho, que vive na miséria com sua filha, lança queixas amargas contra "os estancieiros que por quarenta anos o tinham procurado nas horas de aperto e que agora, na velhice, deixavam-no de lado, como um rebenque velho." Era ele quem, quando jovem, tomava conta da estância do Urutau, que possuía cento e tantas quadras de sesmaria no passado, mas que já estava repartida pela filharada do velho estancieiro chamado Querenciano. Após se embriagar, o velho cai no sono. O escritor, apesar de alguma resistência, ficacom Maria, a filha do velho. A princípio, ela Ihe causa estranhamento por ser muito semelhante, pelo seu físico e pelas suas roupas, a um rapaz; mas, depois, ele se rende a ela.

\section{"Hombre"}

O enredo focaliza a volta do narrador-personagem que, no conto "Bugio Amarelo", deixa a zona fronteiriça e vai para a capital do Rio Grande do Sul. Ele regressa porque era dia de batizado do filho de Pacho, seu afilhado. Dez anos separam a partida do narrador-personagem para a cidade grande da ação desse conto, como verificado no diálogo entre Pacho e ele. Pacho diz que a situação dos contrabandistas, dos "homens do rio", "dos capincheiros" da zona fronteiriça só se agravou com o passar dos anos. Quando o narrador-personagem, no barco de Pacho, indaga que jamais se acostumaria de novo com a situação de contrabando, Pacho diz que ele "não prestava mais pra nada". Depois do desabafo, Pacho pede desculpas. Ambos começam a beber e a contar velhos casos. 


\section{"Velhos"}

O narrador onisciente coloca em evidência, novamente, a vida de gaúchos, já idosos, que foram capatazes de estâncias e ainda moravam com sua família nessas fazendas, embora não exercessem mais atividade, pois a idade os impossibilitava. 0 personagem que se destaca é o velho Cuertino López, o mesmo personagem do conto "Lá no Campo". A ação de desenvolve num domingo, quando Cuertino e sua mulher, Santa, esperam a visita do seu irmão, Sizenando López e de sua esposa, Dona Bica. Esse ritual se repetia há quinze anos, desde que Sizenando "viera capatazear um estabelecimento lindeiro". Todos os domingos eles se visitavam: num, ia Cuertino e Dona Santa, noutro, vinham Sizenando e Dona Bica. Cuertino, antigo capataz do pai de "Dona Maria Luíza Santos Trindade", está preocupado, pois confessa a Sizenando que descobriu que o filho, Neco, andava pulando a janela do quarto da moça. A preocupação não se limita apenas pelo fato de ela ser a herdeira, dona da estância. A questão é que era comprometida, e o noivo vinha visitá-la todo domingo, apesar de, cada vez mais, estar ficando menos tempo com ela. Para os "velhos", é um absurdo haver um romance entre um morador da "casa grande" com um que habita o "galpão"; assim combinam que devem afastar Neco de Maria Luiza a qualquer custo, embora, em muitos momentos, fique nítido que os velhos admiram a atitude de Neco, sua hombridade, ao se relacionar com uma "piguancha" do "pêlo" de Maria Luíza. 


\section{APÊNDICE II - Observações sobre Juan José Saer}

Também na Argentina, Juan José Saer, um escritor de vanguarda, retomou, por meio de um enredo e de técnicas específicas, a figura do "gaucho".

É da seguinte forma que Saer resume sua vida:

"Nací en Serodino, provincia de Santa Fe, el 28 de junio de 1937. Mis padres eran imigrantes sirios. Nos trasladamos a Santa Fe en enero de 1949. En 1962 me fui a vivir al campo, a Colastiné Norte, y en 1968, por muchas razones diferentes, voluntarias e involuntarias, a París. Tales son los hechos más salientes de mi biografía."

Não cita que, na contemporaneidade, é um dos grandes autores da literatura Argentina; é autor de romances, livros de contos e de poesia (En la zona (1960);

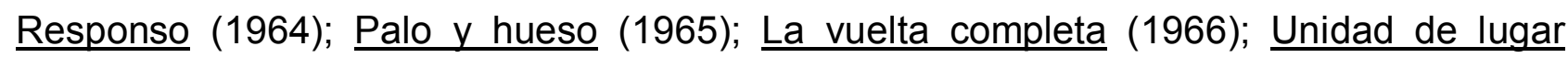
(1967); Cicatrices (1969); El limonero real (1974); La mayor (1976); El arte de narrar (poesía) ( 1977); Nadie nada nunca (1980); El entenado (1983); Narraciones ( 1983); Glosa (1986); Juan José Saer por Juan José Saer (antología personal y estudio de M. T. Gramuglio) (1986); La ocasión (1987); Lo imborrable (1993); La pesquisa (1995)) sem contar que escreveu muitos ensaios também reunidos em livros "La literatura y los nuevos lenguajes", In: América Latina en su literatura (1972); "Narrathon”, In: Caravelle (1975); Une littérature sans qualités (1985); Una literatura sin atributos (1986); "Zama de Antonio di Benedetto", in: Literatura hispanoamericana (1987); "Une littérature européene", in La Quinzenaine Littéraire (agosto, 1987); "Literatura y crisis argentina”, in: Literatura argentina hoy (1989); El río sin orillas (1991); "Il marchait um peu courbé” y "Sobre el procedimiento epistolar", Punto de vista (abril, 1995). 
Quando ele traça sua biografia, chama a atenção sua partida para França, há alguns anos, onde residiu até sua morte, em 11 de junho de 2005. Mas isso, jamais impediu que sua literatura sempre voltasse ao tema da planície ou "llanura" dos Pampas argentino. Ele afirma que "estamos constituídos em gran parte por el lugar donde nacemos. Los primeiro años del animalito humano son decisivos para su desarollo ulterior. La lengua materna lo ayuda a constituir sua realidad. Lengua y realidad son a partir de ese momento inseparables. Lengua, sensación, afecto, emociones, pulsiones, sexualidad: de eso está hecha la patria de los hombres, a la que quierem volver continuamente y a la que llevan consigo donde quiera que vayan. La lengua le da a esa patria su sabor particular."

No livro de ensaio, "El río sin orillas", relata que a vida na Europa tem sido para ele mais gratificante que os anos passados na Argentina, mas todas as vantagens objetivas, que pôde obter no continente europeu, parecem, para ele, destinadas a um outro, um usurpador não muito convencido que, cedo ou tarde, terá que prestar contas ao verdadeiro, ao que nasceu e se criou na "llanura austera"

Essa angústia em relação à identidade que se manifesta na literatura de Saer, também ocorre, não seria exagero de dizer, em grande parte da literatura Argentina, cujos textos, do séc. XIX e XX, manifestam esse sentimento angustiante em busca do nacional, perpetuado por meio da figura do "gaucho", e da literatura que se utiliza de sua imagem numa relação de exaltação e repulsa.

Para explicar melhor essa busca pelo nacional, recorro novamente a Saer o qual afirma que, na primeria metade do século XIX, podia se falar de uma Argentina "clássica", onde a região pampeana ditava os grandes arquétipos: "la llanura, o gado, o índio, o "gaucho", o estancieiro, os grandes rios do litoral. A palavra "clássica" justifica-se porque, apesar das violentas guerras civis, entre Buenos Aires e as províncias, entre liberais e conservadores, entre zonas rurais e cidades, entre índios, brancos e mestiços, até 1860, pelo menos, um sistema patriarcal, organizado pelos proprietários, auto representava-se imaginariamente como uma totalidade cultural, por mais rudimentária que fosse. Os mais irreconciliáveis inimigos tinham certos valores comuns e compartilhavam imagens familiares, que consideravam culturais do lugar que habitavam. "Proprietarios, índios, guachos y soldados pasan el tiempo degollándose mutuamente, pero comparten el mismo desprecio por el que no sabe andar a caballo. Aun Sarmiento que venía de la cordillera, y que escribió Facundo para denotar la barbarie de la cultura de los gauchos, 
cayó, como ya ha sido señalado tantas veces, en las redes sutiles de la fascinación que ejerció sobre él aquello que denostaba."

A Argentina do século XIX é clássica nesse sentido: suas normas, por mais arbitrárias, , por mais "selvagens" que sejam, são transparentes para todos. A imigração maciça, a partir de 1860, inaugurou a "opacidad".

A presença de imigrantes, portadores de outras línguas e outras culturas, e o crescimento ostensivo de uma literatura popular feita por eles representavam uma ameaça. Isso gerou a necessidade de discutir a essência da nacionalidade Argentina e a literatura apropriada para representar essa essência. Assim a zona pampeana, onde também se localiza Buenos Aires, é eleita como lugar privilegiado que irá representar o país inteiro. É o rural ou campesino que a definem, não o elemento citadino; e o seu tipo característico é o "gaucho", símbolo da Argentina até hoje.

Segundo Saer, a Argentina "transformada en todos los planos por las sucesivas olas inmigratorias, se puso a buscar una supuesta identidad nacional escamoteada por la intrusión de lo extranjero, haciendo del Martín Fierro y de la sociedad patriarcal del siglo XIX el prototipo de la esencia nacional"

Foi Leopoldo Lugones, em conferências em 1913, o primeiro a qualificar José Hernandez como poeta nacional. Já Borges rebaixa Martín Fierro de herói nacional "al rango de simple cuchillero"

A opinião de Saer sobre o poema de José Hernández é clara: "las contradicciones morales de Martín Fierro lo descalifican como héroe nacional, pero lo enriquecen en tanto que personaje literario, acrecentando su verdad human y su universalidad" Ainda acrescenta que "atribuirle el privilegio glacial de ser el poema representativo de la nación, equivaldría a empobrecer su dinámica y su misterio."

Por meio dessas observações, é evidente que Saer reconhece o valor literário dessa obra de José Hernández, que, de maneira alguma, deixa de povoar o imaginário do escritor argentino. Saer é leitor e crítico de Martín Fierro. Nesse sentido, pode-se pensar na teoria da estética da recepção, entendida como uma noção que "abrange um duplo sentido: passivo e ativo ao mesmo tempo. Define-se como um ato de face dupla que compreende simultaneamente o efeito produzido pela obra e a maneira como esta é recebida pelo público. Este ou o destinatário podem reagir de vários modos: consumir simplesmente a obra ou criticá-la, admirá-la ou recusá-la, deleitar-se com sua forma, interpretar seu conteúdo, assumir uma interpretação reconhecida ou tentar apresentar 
uma nova. Finalmente, o destinatário pode responder a uma obra produzindo ele próprio uma outra. E assim se realiza o circuito comunicativo literário: o produtor é também um receptor quando começa a escrever. Por meio dessas diversas atividades, o sentido de uma obra está sempre se renovando como resultado do horizonte de expectativas."

Mas, esse escritor, tal como Arregui, ou mesmo Borges, tem uma relação de aproximação e repulsa com a literatura gauchesca, principalmente com a obra Martín Fierro. E quando retoma a figura do "gaucho", coloca-a num enredo passado, num momento (último terço do século XIX) que ainda "existia" essa figura, na tentativa de evidenciar que ela, também envolta na Argentina por uma ideologia que propagava o mito do "gaucho-heroe", está longe de ser "valente, honrada, altiva"; sua natureza "mais humana" é colocada em cena.

Só depois de uma intensa triagem, descobri que o livro "La ocasión" (1987), remete-se a um passado para retomar o "Pampa" e seus habitantes.

Na verdade, há um jogo intertextual explícito em La Ocasión (1987), cuja ação principal (1870) está situada imediatamente antes da escritura e da publicação de Martín Fierro (1872). Mas a intenção do autor não é somente "responder a essa obra de Hernández produzindo outra". Sua intenção é não só dialogar com Martín Fierro, mas também com as diferentes recepções dessa obra de Hernández.

Em La Ocasión, o personagem principal é Bianco, um estrangeiro, ocultista, que foge da França para a Itália por ser acusado de participar da conspiração dos positivistas de Paris. Ao convencer, por sugestão das autoridades européias, campesinos italianos pobres a se instalarem na Argentina, Bianco ganha terras no Pampa. Muda para essa região argentina e resolve criar gado e, com um amigo, Garay López, decide que importar arame da Alemanha, é um excelente negócio para suas economias prosperarem.

É pelo narrador onisciente, que fica colado à figura de Bianco, que vai se desvendando a concepção do estrangeiro, do "de fora" frente àquele mundo "bárbaro". Instaura-se ainda um jogo de aparências x essências. Bianco está sempre bem vestido, 0 que contrasta com a rudeza daquelas terras. Porém, o seu caráter é trepidante, perturbada, de pouca densidade, insegura o que se choca com a solidez da "llanura", lugar propício para os pensamentos, segundo o próprio Bianco.

Se em "Martín Fierro" há o ponto de vista do gaúcho marginalizado quando os alambrados começam a predominar, La ocasión permite um novo olhar sobre esse 
quadro, já que há a visão de um europeu frente ao contexto da criação das estâncias, da imigração, fatores que trouxeram mudanças profundas no panorama sócio-econômico e cultural da Argentina

Apesar de não fazer ecoar plenamente a voz do homem do campo pobre, "La ocasión" , indubitavelmente, dialoga com "Martín Fierro" e busca um ajuste de contas com o passado, para trazer à tona a heterogeneidade da História da nação Argentina. Essa obra de Saer encaixa-se no que alguns críticos do Uruguai e da Argentina chamam de "nueva novela histórica".

Segundo Maria Cristina Pons, "“la novela histórica de fines del siglo XX”, "la novela histórica reciente" o "la novela histórica contemporânea" se caracteriza por la lectura crítica e desmistificadora del passado. Además, tiende a presentar el lado antiheroico o antiépico de la Historia. De esta manera, la novela histórica contemporánea cuestiona la verdad, los heróes y os valores abanderados por la História."

Pons também afirma que a "o novo romance histórico" se produz em conjunturas históricas particulares, ou seja, vai surgir, como acontece nos contos de Faraco e Arregui, num momento de crise. A emergência desse tipo de literatura responde às grandes transformações ou acontecimentos históricos, os quais criam a necessidade de posicionar-se frente à História, ou assumir um historicismo, redifinindo a identidade frente a tais acontecimentos; ou seja, grandes mudanças sócio-históricas impulsionam a produção do "romance histórico do final do século XX"

La Ocasión, primordialmente, pode ser considerado um romance desse gênero, já que possui como pano de fundo o elemento histórico. O enredo transcorre no período que vai desde o inverno de 1870 até o outono de 1871. Mas, para explicar certos acontecimentos, há o retrocesso temporal ao meados da década de 1850. Dois são os temas históricos predominantes no romance: a imigração maciça que tem lugar na Argentina a partir de 1860; e a transformação do campo a partir do sistema de alambrados, ou seja, a partir do momento em que as cercas começam a predominar. A segunda metade do século XIX é, portanto, o marco temporal eleito para a narração.

"A persistência histórica de certos problemas" leva Saer a escrever sobre eles, sem escamotear a realidade,ou seja, a tentar visualizar um passado que desemboca, com todas as suas conseqüências, no presente. Como o próprio escritor argentino analisa em El río sin orillas: 
"En 1647, ya tenemos tres elementos casi constantes de la región: "un puñado de dirigentes que reivindican toda una serie de privilegios, una mayoría de pobres diablos de diversas nacionalidades a los que la miseria empujó a América con la intención de enriquecerse, y una vasta masa anónima, los indios, relegada a las tinieblas exteriores. Hacia 1875 la situación no era diferente y, sin querer exagerar, me atrevería a decir que en 1991 sigue siendo la misma, aunque la modalidad y las magnitudes hayan cambiado. El grito perplejo de los beatniks de Norteamérica, "Quien se robó el sueño americano?", nosotros, los del sur del continente, no necesitamos proferirlo, porque nuestro propio sueño, en todos los sentidos de la palabra, sabemos muy bien quién nos lo robó."

É clara, assim, como na obra de Arregui e Faraco, a procura de Saer por uma posição mais equilibrada frente ao passado, à formação do mito do gaúcho, ao estigma do "gaucho malo", difundida por Sarmiento. Os "gauchos", que vão povoar La Ocasión embora colocados no enredo por meio de breves pinceladas, são bons, são maus, são enganados, mas também enganam, são valentes, mas também apresentam fraquezas; não são colocados numa harmonia perfeita com o mundo pastoril-pampeano. É um "gaucho" que se apresenta como o gaúcho de Faraco como o "gaucho" de Arregui, já que sua heroicidade está em vencer o cotidiano.

E assim como o escritor brasileiro e o uruguaio, Saer retoma não um passado de nostalgia, "um paralisador paraíso perdido" mas revê um "modo de ser" das figuras do Pampa que constitui muitos dos rasgos da "psiquê" latino-americana, marcada por resistências e desistências, opressões e eterna luta na construção de uma identidade baseada numa democracia que proporcione voz a todos e que não resida apenas na formalidade. 


\section{BIBLIOGRAFIA GERAL}

ABADIE, Washington Reyes e ROMERO, Andrés Vázques. Crónica General del Uruguay. (Tomo III, La emancipacion). Montevideo: Ediciones de la Banda Oriental. 1999.

ACOSTA, Alejandro Gonzalez. "La figura del gaucho como elemento de la identidad nacional en Radiografia de la Pampa, de Ezequiel Martinez Estrada" In: Revista de Historia de America. México: n. 117, enero-junio 1994, pp. 23-39. 
AGUIAR, Flávio. "Cultura de Contrabando: estudo sobre os contos de Simões Lopes Neto." In: Revista Vozes Cultura, Ano 86 - Volume 89 (LXXXIX) - n 6, Novembro/Dezembro/1992. p. 13.

AGUIAR, Flávio; MEIHY, José Carlos Sebe Bom; VASCONCELOS, Sandra Guardini T. (organizadores). Gêneros de fronteira: cruzamentos entre o histórico e o literário. São Paulo: Xamã, 1997.

\& VASCONCELOS, Sandra Guardini T. (orgs.) Ángel Rama: Literatura e Cultura na América Latina. São Paulo: Edusp, 2001.

AINSA, Fernando. "La frontera Territorial Argentina: del programma político a la ficción utópica" In: (org.). Fronteiras Culturelles en Amérique Latine. Paris: université de la Sorbonne Nouvelle, n. 13, s. d.

ALVAREZ, Carlos. "O conceito de Estado-Região" In: Fórum 2004. Barcelona, 9 de maio - 26 de setembro de 2004.

AMARAL, A. F. Os Campos Neutrais. Porto Alegre: ed. do autor, 1976.

ANSOLABEHERE. Pablo "Cuentos de la Pampa. Los casos de Alberto Ghiraldo y Benito Lynch" In: Anales de Literatura Hispanoamericana: el cuento criollista y outros estudios, n. 27, Servicio de Publicaciones Universidad Complutense, 1998. p. 92.

ARREGUI, Mario. Líber Falco Montevideo: Arca, 1964.

El Narrador. Montevideo: Arca, 1972.

. Ramos Generales. Montevideo: Arca, 1985.

- Cavalos do Amanhecer. Tradução de Sergio Faraco. Rio de Janeiro:

Francisco Alves Editora, 1982. 
. A cidade silenciosa. Tradução de Sergio Faraco. Porto Alegre: Movimento, 1985.

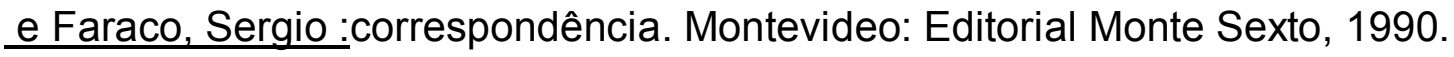

Contos Completos I. Montevideo: Arca, 1992.

Contos Completos II. Montevideo: Arca, 1992.

Autores gaúchos. Cyro Martins. Secretaria de Educação e cultura. Subsecretaria de Cultura. Instituto Estadual do Livros. Porto Alegre, IEL, 1996. p.6.

Autores gaúchos. Sergio Faraco. Secretaria de Educação e cultura. Subsecretaria de Cultura. Instituto Estadual do Livros. Porto Alegre, IEL, 1996. 24pp.

AZEVES, Ángel Héctor. El verso criollo en la política argentina. Buenos Aires: Editorial Universitaria de Buenos Aires, 1995.

BENEDETTI, Mario. "Arregui, Mario (1917-1985). In: Diccionario de Literatura Uruguaya. Montevideo: Arca-Credisol, tomo I, 1987, pp.57-8.

. Literatura Uruguaya siglo XX. Montevideo: Arca, 1988.

BETHELL, Leslie (org.) História da América Latina: da Independência até 1870. v. III. São Paulo: EDUSP; Imprensa Oficial do Estado; Brasília: Fundação Alexandre de Gusmão, 2001.

BITTENCOURT, Gilda Neves da Silva. $\underline{O}$ conto sul-rio-grandense: tradição e modernidade. Porto Alegre: Ed. Universidade/UFRGS, 1999. 
BOLLO, Sarah. Literatura Uruguaya (1807-1975). Montevideo: Universidad de la Republica, 1976.

BORDOLI, Domingo Luis e VISCA, Arturo Sergio. "84 años de Literatura uruguaya".In: Gaceta de la Universidad. Montevideo, n. 28, setiembre de 1963. pp. 18-24.

BOSI, Alfredo. "Narrativa e resistência". In: . Literatura e Resistência. São Paulo: Companhia das Letras, 2002. . "Sobre alguns modos de ler poesia: memórias e reflexões." In: . Leitura de poesia. São Paulo: Ática, 1996. pp. 30-1.

BRANDO, Oscar. "Los cuentos de Mario Arregui" In: RAVIOLLO, Heber e ROCCA, Pablo (org.). História de la Literatura Uruguaya contemporánea. La narrativa del medio siglo.Montevideo: Ediciones de La Banda Oriental, tomo I, 1996. pp.241-256.

BUENO, Francisco da Silveira. Dicionário da língua portuguesa. 11. ed. Rio de Janeiro: FENAME, 1983.

CAETANO, Gerardo e RILLA, José. Historia contemporánea del Uruguay: de la Colônia al Siglo XXI. Montevideo: Editorial Fin de Siglo, 2004.

CANCLINI, Néstor Garcia. Cultura Híbridas, estratégias para entrar e sair da modernidade, Tras. Ana Regina Lessa e Heloisa Pessa Cintrão. São Paulo: Edusp, 1997.

CANDIDO, Antonio. "Visões Radicais do Brasil e de América Latina". In: Teresina etc. Rio de Janeiro: Paz e Terra, 1980. pp.83-95. 
CANTER, Rita. "Martin Fierro em Língua Portuguesa". In: Impressões regionalistas, outras crônicas. Porto Alegre: Difusão de Cultura, 1962, pp. 9-16.

CARNEIRO, David. História da Guerra Cisplatina. São Paulo: Companhia Editora Nacional, 1946.

CECÍN, Antonio Seluja. Nuestros Clásicos: de Bartolomé Hidalgo a Ernesto Herrera. Montevideo, 1985.

CÉSAR, Guilhermino. História da Literatura do Rio Grande do Sul. Porto Alegre: Globo, 1956.

CHIAPPINI, Ligia (Moraes Leite). Modernismo no Rio Grande do Sul: materiais para o seu estudo. São Paulo: IEB/ USP, 1972.

. Regionalismo e Modernismo: o "caso" gaúcho. São Paulo: Ática, 1978.

No entretanto dos tempos: Literatura e História em João Simões Lopes Neto. São Paulo: Martins Fontes, 1988.

. "Do Beco ao Belo: dez teses sobre regionalismo na literatura" "Região, sertão, nação" In: Estudos Históricos: história e região" Rio de Janeiro: vol. 8, n. 15, 1995. pp. 153-159.

- "Forma e História na Crítica Literária Brasileira: a atualidade de Antonio Candido". In: ANDRADE, Luiza et alli. Leituras do Ciclo. Santa Catarina: Editora Grifos. Abralic, 1999. 
. "Martín Fierro e a cultura gaúcha do Brasil”, in: Hernández, José. Martín Fierro: Edición Crítica, org. Élida Lois y Ángel Núñez. Barcelona: Colección Archives, 2001, pp. 691-730.

e Aguiar, Flávio. Literatura e História na América Latina. São Paulo:Edusp, 1993.

. "Multiculturalismo e identidade nacional." In: Fronteiras Culturais: Brasil Uruguai - Argentina. Maria Helena Martins (organizadora). Cotia: Ateliê Editorial, 2002.

CHIAPPINI, Ligia e MARTINS, Maria Helena (Orgs). Cone Sul: fluxos, representações e percepções. São Paulo: Hucitec, 2006.

COSTA, Rogério Haesbaert. Latifúndio e Identidade Regional. Porto Alegre: Mercado Aberto, 1988.

COSSE, Rômulo. "El cuento uruguayo actual, sus modelos culturales y la modernidad". In: “70/'90: Antología del cuento uruguayo”. Montevideo: Librería Linardi y Risso, 1991.

DI BENEDETTO, Antonio. Apud: THUESEN, Evelia A. Romano. "La Ocasión para narrar: historia, realidade y alegoría en un texto de Juan José Saer" In: Nueva revista de Filología Hispánica. México, Tomo XLVII, n. 1, 1999.

ENGLEKIRK, John E. E RAMOS, Margaret M. La narrativa uruguaya: estudio crítico-bibliográfico. Berkeley: University of Califórnia Press, 1967.

FAGUNDES, Antonio Augusto. "E o gaúcho morreu". In: Gonzaga, Sergius e Fischer, Luís Augusto. (org.). Nós, os gaúchos. Porto Alegre: Editora da Universidade do Rio Grande do Sul, 1992, pp. 95-98. 
FARACO, Sergio. Contos Completos. Porto Alegre: L\&PM Editores, 1995.

. Dançar Tango em Porto Alegre. Porto Alegre: L\&PM Pocket,1999.

Rondas de escárnio e loucura. Porto Alegre: L\&PM Editores, 2000.

. "Palavra do autor". Coleção Palavra 3. CD sob a coordenação de Waldemar

Torres. Estúdio Eduardo Prates Criações Sonoras. Porto Alegre: 2003.

. Contos Completos. 2. ed. Porto Alegre: L\&PM, 2004.

FERNÁNDEZ, Christian. "El tamaño de la influencia: gauchesca, criollismo y nación. Sarmietno y Güiraldes leídos por Borges" In: Revista de Literatura Hispánica, n. 49-50, 1999, pp. 9-25.

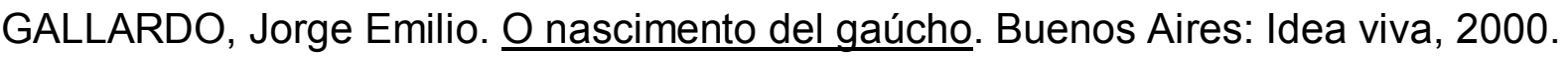

GÁRATE, Miriam. "Atracción y repulsión en torno a la gauchesca de Gauchos y de Gauchos" In: Revista Iberoamericana. N. 192, julio-setiembre 2000 pp. 533-544.

GOMES, Ângela de Castro. História e historiadores. Rio de Janeiro: Editora Fundação Getúlio Vargas, 1996.

GORI, Gastón. La pampa sin gaucho. Buenos Aires: EUDEBA, 1986.

GUTFREIND, leda. A historiografia rio-grandense. 2. ed. Porto Alegre: Ed. Universidade/UFRGS, 1998.

HAESBAERT, Rogério. “Questões e mitos sobre a globalização”. In: Fronteiras e espaço global. STROHAECKER, Tânia Marques (org.). Porto Alegre: Associação dos Geógrafos Brasileiros - Seção Porto Alegre, 1998. 
HALL, Stuart. A identidade cultural na pós modernidade. Tradução Tomaz Tadeu da Silva, Guaracira Lopes Louro. Rio de Janeiro: DP\&A, 4. ed., 2000.

HERNÁNDEZ, José. El gaucho Martín Fierro e La vuelta de Martín Fierro. Espanha: Ediciones Cátedra, 1991.

. Martín Fierro. Tradução de Walmir Ayala. Rio de Janeiro, Ediouro, 1991.

JAGUARIBE, Helio. “América Latina ante o século XXI”. In: Fórum 2004. Barcelona, 9 de maio - 26 de setembro de 2004.

JOB, Ricardo Peró. "Califórnia”. In: "Revista Fronteira Livre”. Jornalista responsável: Francisco Alves. Uruguaiana: Editora Holoedro, setembro de 2005, Ano I, p.26

JOSEF, Bella. História da Literatura Hispanoamericana. Rio de Janeiro: Francisco Alves, , 1989.

LE GOFF, Jacques. História e memória. São Paulo: Unicamp, 1990.

LIMA, Oliveira. D. João VI no Brasil. Rio de Janeiro: Topbooks, 1996.

LIMA, Silvio Julio de Albuquerque. Literatura, folclore e linguística da área gauchesca no Brasil. Rio de Janeiro: A. Coelho Broco Filho (editor), 1962.

LOEDEL, Graciela Mántaras e ARBELECHE, Jorge. Panorama de la Literatura Uruguaya entre 1915 y 1945. Montevideo: 1995.

LOPES NETO, João Simões. Contos Gauchescos. Porto Alegre: Leitura XXI, 2000. 
LOSADA, Alejandro. "Como puede un eoropeo estudiar la literatura latinoamericana". In: Cahier du Monde Hispanique et Luso-Bresilien - Caravelle 45. Toulouse, 1985, pp. $37-46$. Martin Fierro: Gaucho-Heroe-Mito, Introducción a una lectura significativa del Poema. Buenos Aires:Editorial Plus Ultra, 1967.

. "Cultura nacional o literatura revolucionaria". In: Nueva Americana, n`3, Torino: Giulio Eunaudi Editore, 1990, p. 301.

LUDNER, Josefina. El Genero Gauchesco. Un Tratado sobre la Patria. Buenos Aires: Sudamericana, 1988.

LYNCH, John. Las Revoluciones Hispanoamericanas: 1808-1826. Barcelona: Editorial Ariel, 1989.

MARTINS, Cyro. Páginas soltas. Porto Alegre: Movimento, 1994.

MARTINS, Maria Helena (organizadora). Fronteiras Culturais: Brasil - UruguaiArgentina. Cotia: Ateliê Editorial, 2002.

MASINA, Léa. Percursos de Leitura. Porto Alegre: Movimento, 1994.

"O Contrabando na confluência de culturas".In: CASTELLO, lára Regina et alli (org.). Prática de integração nas fronteiras: temas para o Mercosul. Porto Alegre: Ed. da Universidade/UFRGS, Instituto Goethe/ICBA. 1995. 
"El Martín Fierro: Truísmos e avatares da crítica literária no Brasil" (Forschungsbericht, unveröffentlicht, 2001 - inédito)

- "Netto perde sua alma, de Tabajara Ruas: identidade fronteiriça e intervocalidade." In: In: Pampa e Cuttura: de Fierro a Netto. CHIAPPINI, Ligia; MARTINS, Maria Helena e PESAVENTO, Sandra Jatahy (Organizaoras). Porto Alegre: Editora da UFRGS/ Instituto Estadual do Livro, 2004.

MENESES, Ulpiano Bezerra. "Identidade Cultural e arqueologia". In: BOSI, Alfredo. Cultura brasileira: temas e situações. 4. Ed. Ática: São Paulo, 1999.

MEYER, Augusto. "Gaúcho, história de uma palavra". In: Prosa dos Pagos. Rio de Janeiro: Liv. São José, 1960.

MONTALDO, Graciela. "Nacionalismo, regionalismo: identidades" In: Revista Río de la Plata: culturas 17-18. Actas del Quinto Congresso Internacional del CELIRP. Paris: 3 , 4, 5 de julio 1996. p. 43-55.

MORAES, Santos. "O conto: sua história no Brasil. In: Revista Cultura. Brasília: Publicação Oficial do Ministério da Educação e Cultura, ano 4, n. 14, out./dez. 1974. pp. 17-23.

MORO, Eoná. História e Literatura em O Continente de Erico Verissimo. Dissertação de mestrado. Setembro de 2001, FFLCH - USP.

NEYRA, Juan Carlos. Introduccion Criolla al Martín Fierro. Buenos Aires: Librería HUEMUL S.A, 1979.

NITRINI, Sandra. Literatura Comparada: História, Teoria e Crítica. São Paulo: Edusp, 2000.

NORONHA, Edgard Magalhães. Direito Penal. São Paulo: Saraiva, $4^{\circ}$ v., 1983. 
NÚÑEZ, Ángel. Acerca de la cultura nacional y latinoamericana. Buenos Aires : Ediciones Pueblo Entero, Buenos Ayres, s.d.

ORNELLAS, Manoelito de. Gaúchos e beduínos :a origem étnica e a formação social do Rio Grande do Sul. 4.Ed. Porto Alegre: Martins Livreiro, 1999. (1. Ed. - 1948).

PADOIN, Maria Medianeira. Federalismo Gaúcho: fronteira platina, direito e revolução. Coleção brasiliana novos estudos, v. 3. São Paulo: Companhia Editora Nacional, 2001.

PEREIRA, Maria Antonieta. "A tela e o texto : literatura e trocas culturais no Cone Sul" In: Revista Iberoamericana. N. 192, julio-setiembre 2000, pp. 617-623.

PESAVENTO, Sandra Jatahy. "Erico e a história." In: BORDINI, Maria da Glória. Erico Verissimo: o escritor no tempo. Porto Alegre: SULINA/SMC, 1990. . "José Lins do Rego e Cyro Martins sob o olhar da história." In: MARTINS, Maria Helena (org.). Cyro Martins 90 anos. Porto Alegre: CELPCyro Martins: IEL: CORAG, 1999.

. "Fronteiras e Intertextualidade em "O Continente" de Erico Verissimo." In: Pampa e Cuttura: de Fierro a Netto. CHIAPPINI, Ligia; MARTINS, Maria Helena e PESAVENTO, Sandra Jatahy (Organizaoras). Porto Alegre: Editora da UFRGS/ Instituto Estadual do Livro, 2004, p.110.

PONS, Maria Cristina. Memórias del olvido . La novela histórica de fines del siglo XX. México: Siglo Veintiuno Editores, 1996.

RABUSKE, Arthur. "O gaúcho Martín Fierro e Antonio Chimango" In: Estudos Leopoldenses. Vale do Rio dos Sinos: UNISINOS, n. 39, 1977. pp.9-94. 
RAMA, Angel. "El Sistema Literario de la Poesía Gauchesca" In: Poesía Gauchesca. Caracas: Biblioteca Ayacucho, s.d.

- Los gauchopoliticos Rioplatenses: literatura y Sociedad. Buenos Aires: Calicanto, 1976.

. Novisimos narradores hispano-americanos en marcha (1964-1980). Mexico: Marcha Editores, 1981. 1. Ed.

. La critica de la cultura en America Latina. Venezuela: Biblioteca Ayacucho, s. d. v. 119 .

. "Mario Arregui: interrogación ética del hombre". In: ARREGUI, Mario. $\underline{\text { Cuentos }}$ Completos I. Montevideo: Arca, 1992.

REIN, Mercedes. "Mario Benedetti y el projecto cultural de 45". In: RAVIOLLO, Heber e ROCCA, Pablo (org.). Historia de la Literatura Uruguaya contemporanea. La narrativa del medio siglo. Montevideo: Ediciones de La Banda Oriental, 1996.

RELA, Walter. Diccionario de escritores uruguayos. Montevideo: Editora de la Plaza, 1986. pp. 31-33.

ROCCA, Pablo. História de la Literatura Uruguaya Contemporánea. Montevideo: Ediciones de la Banda Oriental, 1996.

. Prólogo do livro El cuento rural (1920-1940). Montevideo: Ediciones de la Banda Oriental, 1998. 
"A narrativa pós-gauchesca: limites e abrangência de um discurso."In: Pampa e cultura: de Fierro a Netto. CHIAPPINI, Ligia; MARTINS, Maria Helena e PESAVENTO, Sandra Jatahy (Organizaoras). Porto Alegre: Editora da UFRGS/ Instituto Estadual do Livro, 2004.

ROJAS, Ricardo. Historia de la literatura argentina: Los Gauchos. Buenos Aires: Otero y Compañia, 1916.

ROMERO, Margarita \& IGLESIAS, Lídia. Mario Arregui y el jogo de la palabra. Montevideo: Arca, 1994.

ROSA, Julio C. da. e ROSA, Juan Justino da. Antologia del cuento criollo del Uruguay, 1979.

RUAS, Tabajara. Os varões assinalados (o romance da Guerra dos Farrapos). Porto Alegre: LP\&M, 1985.

SAER, Juan José. Juan José Saer por Juan José Saer. Buenos Aires : Celtia, 1986.

La ocasión. Barcelona: Ediciones Destino Áncora y Delfin, 1987.

. El río sin orillas: tratado imaginario. Buenos Aires: Alianza Editorial S.A. , 1991.

.Prólogo à obra de Juan L. Ortiz" In: ORTIZ, Juan L. Obra completa. Argentina: Universidad Nacional del Litoral, 1996.

. Una literatura sin atributos. Buenos Aires: Colección Poesía y Poética, 1996. 
"Lección Inaugural: tradición y cambio" In: Revista Río de la Plata: culturas

17-18. Actas del Quinto Congresso Internacional del CELIRP. Paris: 3, 4, 5 de julio 1996. p. 5-18.

VÁRIOS AUTORES. Diversidade étnica e identidade gaúcha. Santa Cruz do Sul: Editora da UNISC, 1994.

\section{Sites consultados:}

http://pessoal.portoweb.com.br/sergiofaraco/entrevista.htm

http://es.wikipedia.org/wiki/F\%C3\%A9lix_de_Azara)

http://www.mec.gub.uy/academiadeletras/DANNOMBRE/Bauza_Fco.htm

http://www.bibliotecasvirtuales.com/biblioteca/LiteraturaLatinoamericana/FSanchez/index. asp

http://www.temakel.com/arthudson.htm

http://www.todoargentina.net/Literatura_argentina/Biografias_de_literatura/Lucio_V_ Mansilla/lucio_v_mansillaa.htm 